\title{
※USGS
}

science for a changing world

Studies by the U.S. Geological Survey in Alaska, 2007

Mesozoic Magmatism and Base-Metal Mineralization in the Fortymile Mining District, Eastern Alaska-Initial Results of Petrographic, Geochemical, and Isotopic Studies in the Mount Veta Area

Professional Paper 1760-A

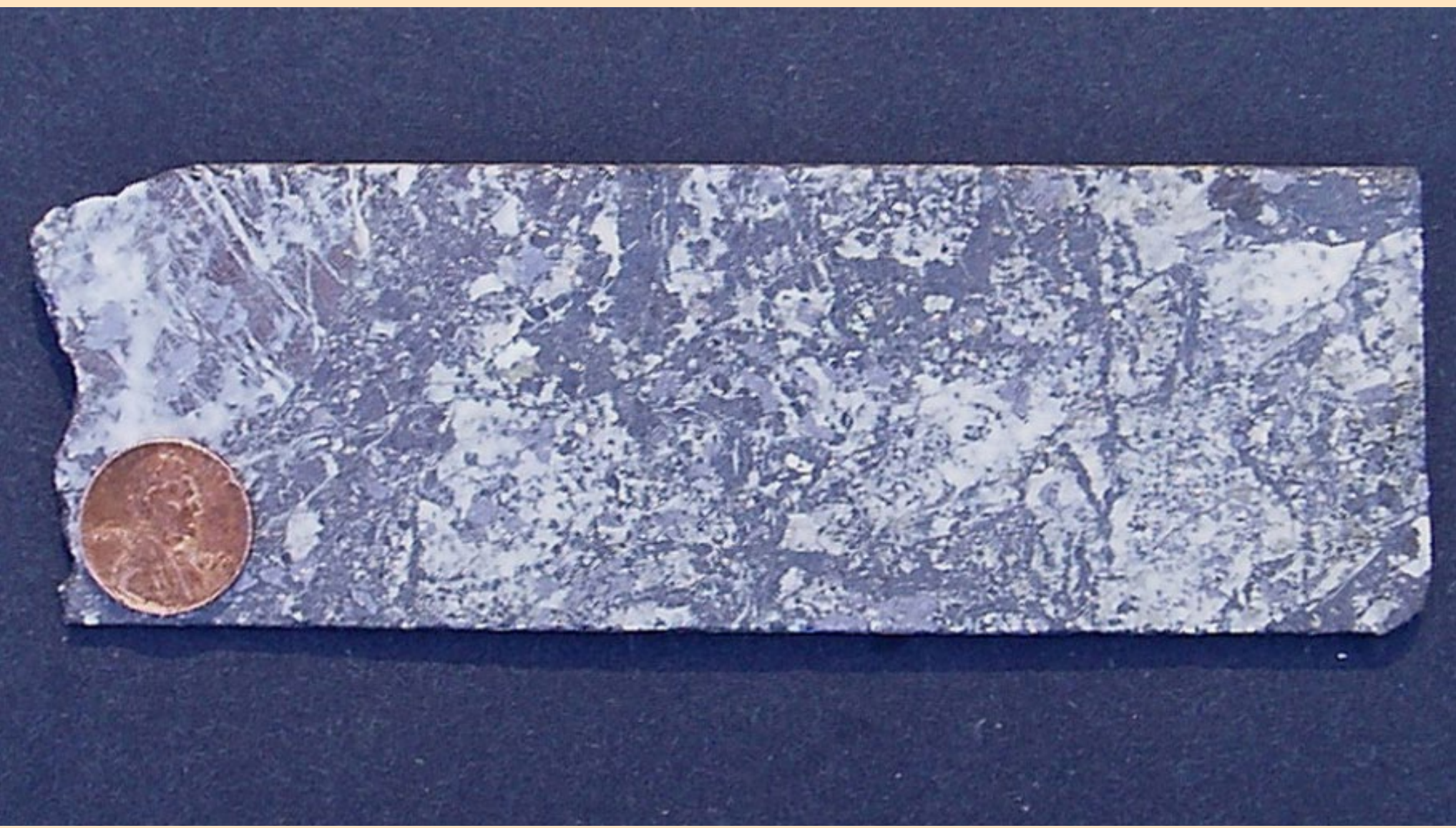

U.S. Department of the Interior U.S. Geological Survey 
This page intentionally left blank 
Studies by the U.S. Geological Survey in Alaska, 2007

Edited by Peter J. Haeussler and John P. Galloway

\section{Mesozoic Magmatism and Base-Metal Mineralization in the Fortymile Mining District, Eastern Alaska- Initial Results of Petrographic, Geochemical, and Isotopic Studies in the Mount Veta Area}

By Cynthia Dusel-Bacon, John F. Slack, John N. Aleinikoff, and James K. Mortensen

Professional Paper 1760-A 


\section{U.S. Department of the Interior DIRK KEMPTHORNE, Secretary}

\section{U.S. Geological Survey Mark D. Myers, Director}

\section{U.S. Geological Survey, Reston, Virginia: 2009}

This report and any updates to it are available online at: http://pubs.usgs.gov/pp/1760/a/

For more information about the USGS and its products:

Telephone: 1-888-ASK-USGS (1-888-275-8747)

World Wide Web: http://www.usgs.gov/

Any use of trade, product, or firm names in this publication is for descriptive purposes only and does not imply endorsement by the U.S. Government.

Although this report is in the public domain, it may contain copyrighted materials that are noted in the text. Permission to reproduce those items must be secured from the individual copyright owners.

Produced in the Western Region, Menlo Park, California

Manuscript approved for publication, December 12, 2008

Text edited by Tracey Suzuki

Layout and design by Stephen L. Scott

Suggested citation:

Dusel-Bacon, C., Slack, J.F., Aleinikoff, J.N., and Mortensen, J.K., 2009, Mesozoic magmatism and base-metal mineralization in the Fortymile mining district, eastern Alaska-Initial results of petrographic, geochemical, and isotopic studies in the Mount Veta area, in Haeussler, P.J., and Galloway, J.P., Studies by the U.S. Geological Survey in Alaska, 2007: U.S. Geological Survey Professional Paper 1760-A, 42 p. [http://pubs.usgs.gov/pp/1760/a/].

FRONT COVER

Photograph of mineralized drill core from the Little Whiteman base- and precious-metal carbonate replacement prospect in the Fortymile mining district, eastern Alaska. Coarse sphalerite (dark-gray) and minor galena (light gray) occur in a gangue (white) of calcite and lesser quartz. Sample is from $107.0 \mathrm{~m}$ depth in hole 4 that was drilled in 2007 by Full Metal Minerals, USA, Inc. Bulk geochemical analysis of this sample shows 22.2 percent Zn, 14.6 percent $\mathrm{Pb}, 0.472$ percent Cu, 190 ppm Ag, and 19.7 ppm In. (USGS photograph by John Slack) 


\section{Contents}

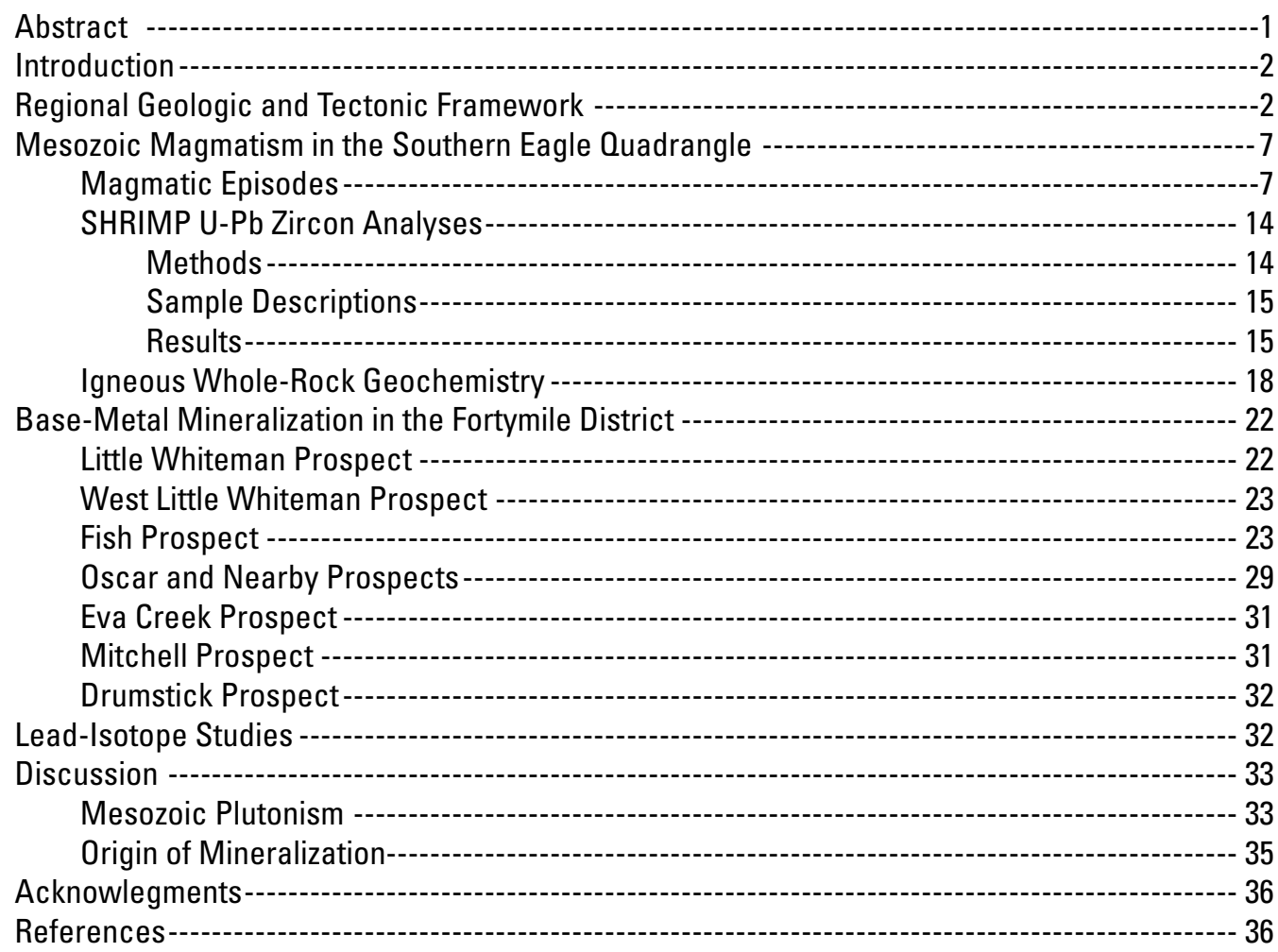

\section{Figures}

1. Paleozoic tectonic assemblages of the northern Cordillera---:-

2. Generalized geologic map of east-central Alaska and adjacent part of Yukon -------------4

3. Generalized geologic map of the eastern Fortymile River area showing locations of $\mathrm{U}-\mathrm{Pb}$ dating samples from Mesozoic plutonic rocks and the Lead Creek

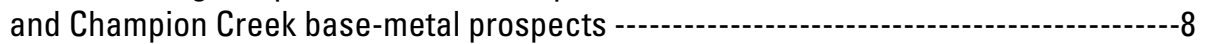

4. Simplified geologic map of the southwestern part of the Eagle quadrangle showing locations of base-metal occurrences and selected igneous crystallization ages and $\mathrm{U}-\mathrm{Pb}$ zircon ages

5. Geologic compilation of part of the Fortymile project area being explored by Full Metal Minerals, USA, Inc., showing locations of base-metal prospects and mapped faults

6. Representative photomicrographs of selected igneous rocks in the Fortymile district for which new U-Pb ages are reported

7. Representative cathodoluminescence images and concordia plots of $\mathrm{U}-\mathrm{Pb}$ data obtained by SHRIMP-RG analysis of zircons in samples from the

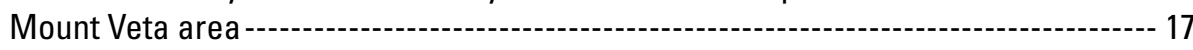

8. Selected discrimination diagrams showing geochemical data for Mesozoic igneous rocks from the Fortymile district-

9. Primitive mantle-normalized plots of trace-element data for Fortymile Mesozoic igneous rocks ---------------------------------------------------------20

10. Photographs and photomicrographs showing textural features of Little Whiteman drill core 
11. Photos and photomicrographs of Fish prospect drill core--------------------------- 28

12. Photos and photomicrographs showing textural features of surface samples

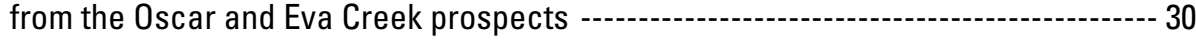

13. ${ }^{207} \mathrm{~Pb} /{ }^{204} \mathrm{~Pb}$ versus ${ }^{206} \mathrm{~Pb} /{ }^{204} \mathrm{~Pb}$ diagram for $\mathrm{Pb}$ in sulfides from mineral occurrences and in feldspars from igneous rocks from east-central Alaska and western Yukon

\section{Tables}

1. New U-Pb ages and descriptions of Mesozoic igneous samples from the Forty-

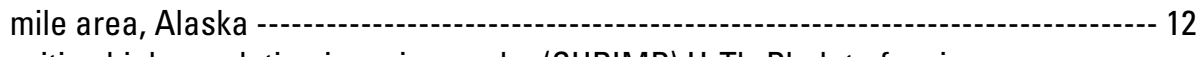

2. Sensitive high-resolution ion microprobe (SHRIMP) U-Th-Pb data for zircon

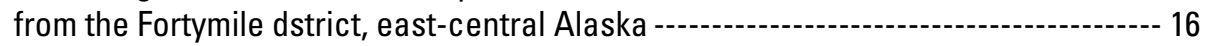

3. Whole-rock geochemical analyses of dated Mesozoic rocks from the Fortymile

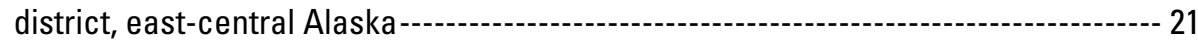

4. Whole-rock chemical analyses of mineralized samples from the Fortymile

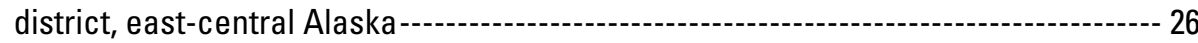

5. Lead-isotopic compositions of sulfide samples from the Fortymile district, east central-Alaska 


\title{
Mesozoic Magmatism and Base-Metal Mineralization in the Fortymile Mining District, Eastern Alaska- Initial Results of Petrographic, Geochemical, and Isotopic Studies in the Mount Veta Area
}

\author{
By Cynthia Dusel-Bacon', John F. Slack', John N. Aleinikoff', and James K. Mortensen²
}

\begin{abstract}
We present here the initial results of a petrographic, geochemical, and isotopic study of Mesozoic intrusive rocks and spatially associated $\mathrm{Zn}-\mathrm{Pb}-\mathrm{Ag}-\mathrm{Cu}-\mathrm{Au}$ prospects in the Fortymile mining district in the southern Eagle quadrangle, Alaska. Analyzed samples include mineralized and unmineralized drill core from 2006 and 2007 exploration by Full Metal Minerals, USA, Inc., at the Little Whiteman (LWM) and Fish prospects, and other mineralized and plutonic samples collected within the mining district is part of the USGS study. Three new ion microprobe U-Pb zircon ages are: $210 \pm 3 \mathrm{Ma}$ for quartz diorite from LWM, $187 \pm 3$ Ma for quartz monzonite from Fish, and $70.5 \pm 1.1 \mathrm{Ma}$ for altered rhyolite porphyry from Fish. We also present 11 published and unpublished Mesozoic thermal ionization mass spectrometric U-Pb zircon and titanite ages and whole-rock geochemical data for the Mesozoic plutonic rocks. Late Triassic and Early Jurassic plutons generally have intermediate compositions and are slightly foliated, consistent with synkinematic intrusion. Several Early Jurassic plutons contain magmatic epidote, indicating emplacement of the host plutons at mesozonal crustal depths of greater than $15 \mathrm{~km}$. Traceelement geochemical data indicate an arc origin for the granitoids, with an increase in the crustal component with time.

Preliminary study of drill core from the LWM Zn$\mathrm{Pb}-\mathrm{Cu}-\mathrm{Ag}$ prospect supports a carbonate-replacement
\end{abstract}

\footnotetext{
${ }^{1}$ U.S. Geological Survey

${ }^{2}$ Department of Earth and Ocean Sciences, University of British Columbia, Vancouver, BC V6T 1Z4, Canada
}

model of mineralization. LWM massive sulfides consist of sphalerite, galena, and minor pyrite and chalcopyrite, in a gangue of calcite and lesser quartz; silver resides in SbAs-Ag sulfosalts and pyrargyrite, and probably in submicroscopic inclusions within galena. Whole-rock analyses of LWM drill cores also show elevated In, an important metal in high-technology products. Hypogene mineralized rocks at Fish, below the secondary Zn-rich zone, are associated with a carbonate host and also may be of replacement origin, or alternatively, may be a magnetite-bearing $\mathrm{Zn}$ skarn. $\mathrm{Cu}-\mathrm{Zn}-\mathrm{Pb}-\mathrm{Ag}-\mathrm{Au}$ showings at the Oscar prospect occur in marble-hosted magnetite and pyrrhotite skarn that is spatially related to the stocks, dikes, and sills of the Early Jurassic syenite of Mount Veta. Mineralized rocks at the Eva Creek Ag-Zn-Pb-Cu prospect are within $1.5 \mathrm{~km}$ of the Mount Veta pluton, which is epidotized and locally altered along its contact with metamorphosed country rock east of the prospect.

We report five new sulfide $\mathrm{Pb}$-isotopic analyses from the LWM, Oscar, and Eva Creek prospects and compare these sulfide $\mathrm{Pb}$-isotopic ratios with those for sulfides from nearby deposits and prospects in the Yukon-Tanana Upland and with feldspar Pb-isotopic ratios for Mesozoic plutons in the region. Disparities between the $\mathrm{Pb}$-isotopic ratios for sulfides and igneous feldspars are consistent with a carbonate-replacement model for both the LWM and Eva Creek prospects. The presence in the Fortymile district of base-metal sulfides within both calc-silicaterich skarns and the calc-silicate-free carbonate replacement deposits may reflect multistage mineralization by magmatic-hydrothermal systems during the emplacement of two or more magmatically unrelated igneous intrusions. Alternatively, all of the mineralized occurrences could be products of one regionally zoned system that formed during the intrusion of a single pluton. In addition 
to the likely origin of some of the base-metal occurrences by intrusion-related hydrothermal fluids, proximity of the LWM prospect to the northeast-striking, high-angle Kechumstuk Fault suggests that fluid flow along the fault also played an important role during carbonate-replacement mineralization.

\section{Introduction}

The Fortymile mining district of eastern Alaska, which includes much of the Eagle quadrangle (Sturmann and Clement, 1993), has long been known as a valuable source of placer gold (Prindle, 1909; Saunders, 1967; Yeend, 1996). Prospecting and mineral exploration also have been done at a number of base- and precious-metal occurrences in the district, particularly in the Mount Veta area in the southwestern part of the Eagle quadrangle, and in the Lead Creek and Champion Creek areas in the north-central part of the quadrangle (summarized by Werdon and others, 2004, and references therein). Recent exploration was done by Full Metal Minerals, USA, Inc., (FMM) at several base- and precious-metal prospects in the Mount Veta area during 2006 and 2007; exploration continues in 2008. The FMM exploration has included diamond drilling at two of the most promising prospects, Little Whiteman (LWM) and Fish, as well as detailed mapping and geochemical sampling at several others, including West Little Whiteman (West LWM), Oscar, and Eva Creek. These prospects are located within the selected or conveyed lands of the Fortymile block of Doyon, Ltd., a Native Regional Corporation. Results from this exploration, together with those from prior exploration in the region, indicate a potential for previously unrecognized carbonate-replacement and skarn base-metal and silver deposits in the Fortymile district (McLeod, 2008; Light and others, 2008).

This paper summarizes the initial results of a study, begun by the U.S. Geological Survey (USGS) in 2007, to characterize the nature and extent of the $\mathrm{Zn}-\mathrm{Pb}-\mathrm{Ag}-\mathrm{Cu}-\mathrm{Au}$ prospects, their cover and associated metasedimentary and metavolcanic host rocks and igneous intrusions, as well as the thermal and structural history of bedrock units in the Mount Veta area of the Eagle quadrangle. We present here the results of petrographic, geochemical, and isotopic analyses of FMM drill-core samples that we collected in Fairbanks and Chicken, Alaska, in July 2007 and at the Vancouver headquarters of FMM in January 2008 and surface samples that we collected at several prospects in July 2007. Also included in our data sets and discussion are two $\mathrm{Pb}$-isotopic analyses of galena previously analyzed for FMM by Mortensen in 2006, and U-Pb zircon and titanite ages and whole-rock geochemical data for Mesozoic plutons collected from the Fortymile district during the 1990s by Dusel-Bacon (Dusel-Bacon and others, 1995, 2002; Hansen and Dusel-Bacon, 1998).

Photomicrographs and geochemical analyses of mineralized core and surface samples presented here only partially characterize the mineralized rocks based on our preliminary observations. However, the compilation of $\mathrm{U}-\mathrm{Pb}$ ages of Mesozoic plutons and the sulfide $\mathrm{Pb}$-isotopic data reported in this paper are adequate to establish several episodes of Mesozoic magmatism and to constrain the unresolved relation among magmatism, mineralization, and regional tectonism.

\section{Regional Geologic and Tectonic Framework}

Base-metal prospects and Mesozoic magmatic episodes in easternmost Alaska that are the focus of this paper are associated with the Fortymile River and Nasina assemblages in the northern Cordillera (western part of the orange unit on figure 1; fig. 2; Dusel-Bacon and others, 2002, 2006). The Fortymile River assemblage comprises amphibolite-facies metasedimentary and metavolcanic rocks, marble, and granodioritic to tonalitic orthogneiss. U-Pb zircon analyses from intermediate-composition gneiss and associated, likely comagmatic, granodiorite and volumetrically minor augen gneiss, and metarhyolite tuff(?) in the Eagle and Dawson quadrangles (fig. 2) yield Early Mississippian ( $355.2 \pm 2.1$ to $341.2 \pm 4.8 \mathrm{Ma}$ ) crystallization ages; one sample of augen orthogneiss gives a slightly older $(360.7 \pm 2.3 \mathrm{Ma}) \mathrm{U}-\mathrm{Pb}$ age at the Devonian-Mississippian boundary (Dusel-Bacon and others, 2006, and references therein). Zircon U-Pb crystallization ages (360-345 Ma) of metaplutonic rocks in the Fortymile River assemblage in the adjacent Stewart River quadrangle in Yukon (fig. 2) overlap this range (Villeneuve and others, 2003). The only fossil age control for the Fortymile River assemblage is provided by a Late Meramecian to early Sakmarian (mid-Mississippian to early Early Permian) age range for conodonts from a marble body near Alder Creek (fig. 8; Dusel-Bacon and Harris, 2003). A minimum protolith age for the assemblage is tentatively provided by a U-Pb zircon age of $263 \pm 1.5$ Ma from an undeformed granitic dike that intrudes the assemblage along the Fortymile River (Dusel-Bacon and others, 2006). Trace-element geochemical data for Fortymile River assemblage amphibolite (metabasalt) and orthogneiss indicate that magma generation occurred in 


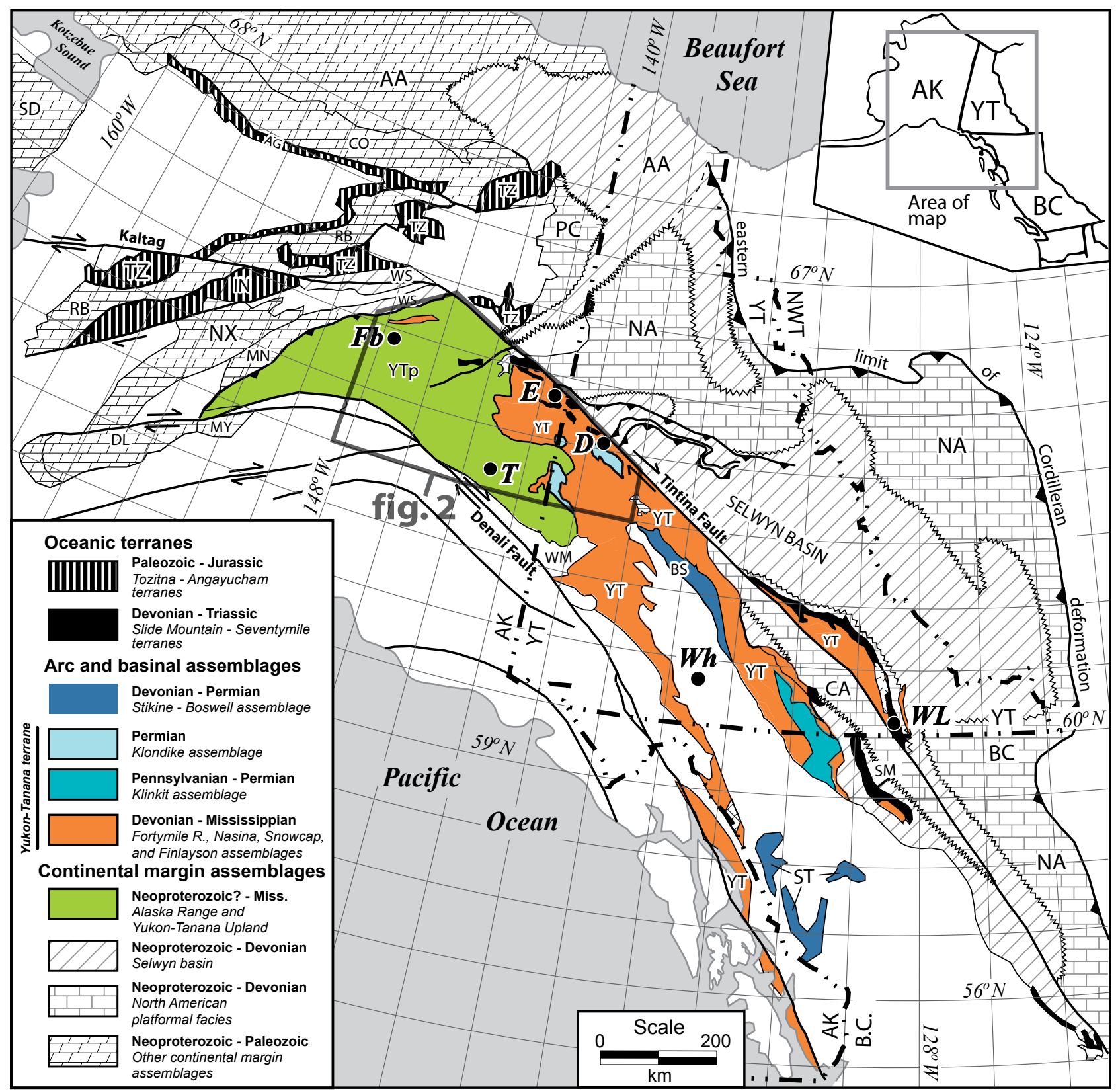

Figure 1. Paleozoic tectonic assemblages of the northern Cordillera (modified from Wheeler and McFeely, 1991; Silberling and others, 1992; Foster and others, 1994; and Dusel-Bacon and others, 2006). Lithotectonic terranes and assemblages: AA - Arctic Alaska (includes Endicott Mountains, North Slope, and Skajit allochthon); AG - Angayucham; BS - Boswell; CA - Cassiar; CO Coldfoot (schist belt of southern Brooks Range); DL - Dillinger; IN - Innoko; MN - Minchumina; MY - Mystic; NA - North American miogeocline; NX - Nixon Fork; PC - Porcupine; RB - Ruby; SD - Seward; SM - Slide Mountain - Seventymile; ST - Stikine (Asitka); TZ - Tozitna; WM - Windy-McKinley; WS - Wickersham; $\mathrm{YT}_{\mathrm{p}}$ - Parautochthonous continental margin in Yukon-Tanana Upland and Alaska Range; YT - Yukon-Tanana in easternmost Alaska, Yukon, and B.C. Other abbreviations: AK - Alaska; BC British Columbia; D - Dawson; E - Eagle; Fb - Fairbanks; NWT - Northwest Territories; Wh - Whitehorse; WL - Watson Lake; T - Tok; YT - Yukon. Unpatterned areas are undivided accreted terranes. 


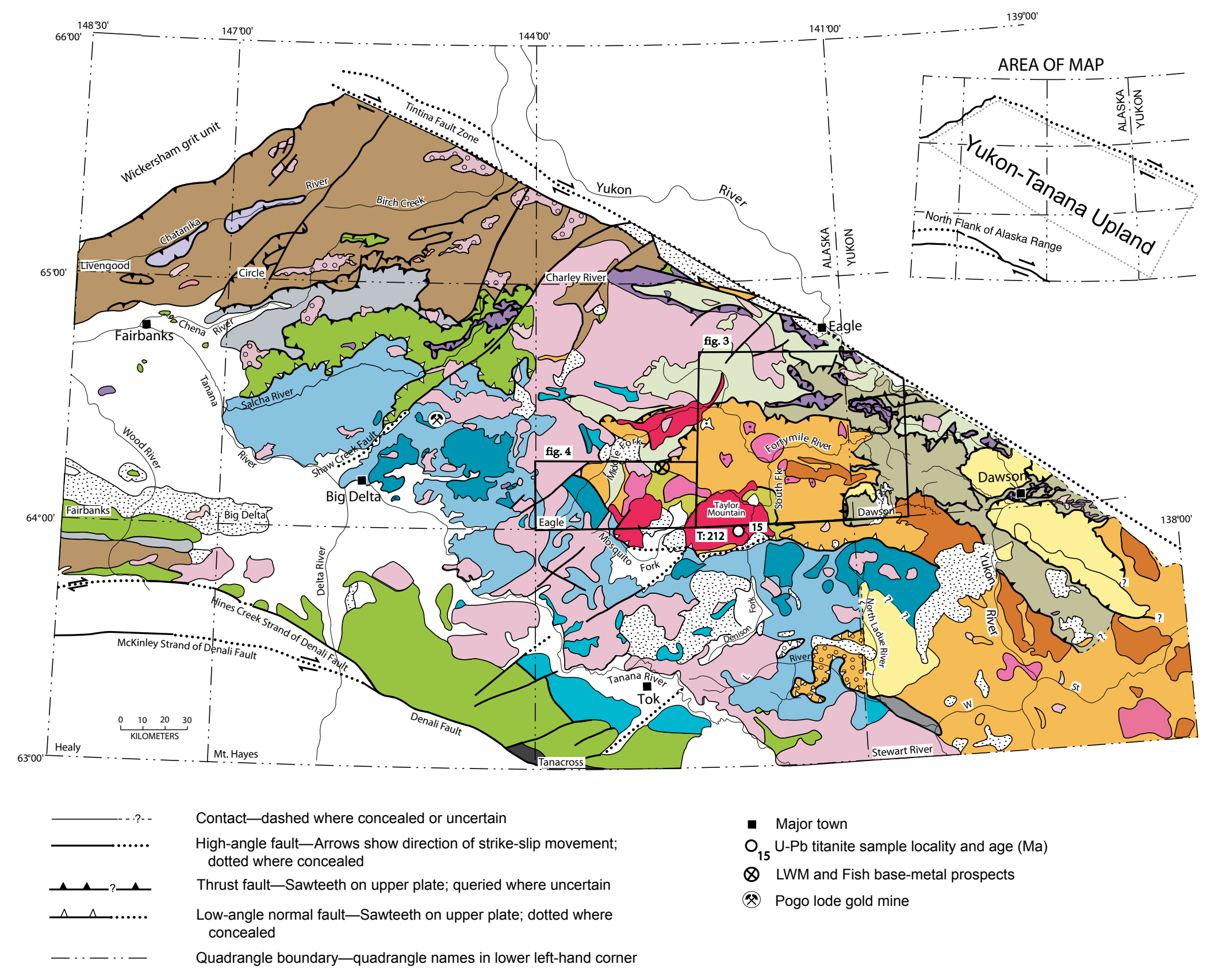




\section{LEGEND}

Sedimentary and volcanic rocks (Cretaceous-Tertiary) (PARAUTOCHTHONOUS)

\section{PLUTONIC ROCKS}

Post-tectonic granitoids (Tertiary)

Post-tectonic granitoids (Cretaceous)

Syntectonic to post-tectonic granitoids (Early Jurassic)

Syntectonic to post-tectonic granitoids (Late Triassic)

\section{OCEANIC AND HIGH-PRESSURE ASSEMBLAGES}

Seventymile terrane Peridotite, greenstone, chert, and limestone (Mississippian-Triassic)

Chatanika assemblage Eclogite, marble, and schist

\section{ARC AND BASINAL ASSEMBLAGES} (ALLOCHTHONOUS)

Klondike Schist-Greenschist-facies felsic

metavolcanic rocks, and minor metasedimentary and felsic orthogneiss shown by $Y$ pattern (Permian)

Fortymile River assemblage-Amphibolite-facies and granodioritic to tonalitic orthogneiss (shown by rusty brown color) (Mississippian)

Ladue River unit-Greenschist-facies schist, and minor mafic and felsic metaigneous rocks (Late Devonian-Early Mississippian)

Chicken Metamorphic Complex-Greenschist-facies intermediate composition to mafic metaigneous rocks, marble, slate, and quartzite (Mississippian?)

Nasina assemblage, non-carbonaceous unit-

Greenschist-facies semischist phyllite, marble, and felsic metavolcanic rocks (Early Mississippian)

Nasina assemblage, carbonaceous unit-

Greenschist-facies carbonaceous rocks, and Early

Mississippian and Permian felsic metavolcanic rocks

Figure 2. Generalized geologic map of east-central Alaska and adjacent part of Yukon. Geology in Alaska from Foster (1992) and Dusel-Bacon and others $(1993,2002)$ and in Yukon from Mortensen $(1988,1996)$, Gordey and Makepeace (1999), and J.K. Mortensen (unpublished mapping). Unpatterned areas are Neoproterozoic to Cambrian and Devonian sedimentary rocks north of the Tintina Fault, and Quaternary surficial deposits elsewhere. Sample number next to $\mathrm{U}-\mathrm{Pb}$ age shown in the northern Tanacross quadrangle is referred to in tables 2 and 3.

Butte assemblage, Totatlanika Schist, Wood River assemblage, and Hayes Glacier, Jarvis, and Macomb belts-Greenschist-facies semischist, phyllite, marble, and Late Devonian-Early Mississippian felsic

Blackshell and Dan Creek units, and Keevy Peak FmGreenschist-facies carbonaceous rocks, slate, marble, stretched-pebble conglomerate, and Late Devonian-Early Mississippian felsic rocks

Healy schist-Quartz-sericite schist, quartzite, chlorite schist, marble, carbonaceous schist, metagabbro, and Late Devonian metaporphyry

Fairbanks-Chena assemblage-Greenschist- to amphibolite-facies pelitic schist, quartzite, marble, an

ake George assemblage-Amphibolite-facies pelitic schist, amphibolite, and quartzite; Late Devonian and darker blue

Windy terrane-Metasedimentary rocks (Devonian and Silurian), and mafic intrusions 
an arc setting (Dusel-Bacon and Cooper, 1999; DuselBacon and others, 2006).

The Nasina assemblage comprises a greenschistfacies sequence of variably carbonaceous quartzite, phyllite, and schist; marble and greenstone; and minor metatuff of both Mississippian and Permian age (DuselBacon and others, 2006). Poorly preserved conodonts from noncarbonaceous rocks exposed along the banks of the Yukon River, indicate a possible Mississippian age for at least part of the Nasina assemblage (Dusel-Bacon and Harris, 2003).

The Nasina assemblage passes laterally into interlayered amphibolite, quartz-biotite schist, and marble of the Fortymile River assemblage near the Yukon-Alaska border (fig. 2). Mortensen (1988) recognized some interlayering of strata of both the Fortymile River and Nasina assemblages just east of the border; additional observations along the Fortymile River in the same area have shown that rock types characteristic of the two assemblages are interlayered on a scale of $10 \mathrm{~s}$ to $100 \mathrm{~s}$ of meters. Elsewhere, thrust faults typically separate the Nasina and Fortymile River assemblages along many of their contacts (Foster, 1992; fig. 2). Both assemblages are intruded by intermediate-composition plutons of Late Triassic, Early Jurassic, and, rarely, mid- and Late Cretaceous age. Based on the locally interlayered and transitional nature of the contacts between the Fortymile and Nasina assemblages, the overlapping Mississippian protolith ages, and the arc signatures of metaigneous rocks in both assemblages, Dusel-Bacon and others (2006) proposed that volcanic edifices and reefs of the Fortymile River assemblage developed adjacent to or within a marginal basin that collected the sediments of the Nasina assemblage, and that subsequent thrust faulting juxtaposed rocks from different parts of a marginal/back-arc basin outboard of the North American continental margin. Continuation of this tectonic setting for the Fortymile River and Nasina assemblages into latest Paleozoic and early Mesozoic time is indicated by the occurrence of Permian felsic metavolcanic and hypabyssal rocks in the Nasina assemblage, the Permian undeformed granitic dike that intrudes Fortymile River assemblage rocks at one locality, and the presence of Late Triassic to Early Jurassic plutons that cut both units (figs. 2-4). Permian metatuff and weakly to strongly foliated bodies of quartz monzonitic to granitic composition also are present in the Klondike Schist (Mortensen, 1990, 1992; Villeneuve and others, 2003), suggesting a shared tectonic setting of this unit with the Fortymile and Nasina assemblages during the Permian (Dusel-Bacon and others, 2006).

The Chicken Metamorphic Complex of Werdon and others (2001) was defined during mapping east of the
Taylor Mountain batholith to consist of greenschist-facies metavolcanic rocks and subordinate metagabbro, metadiabase, metalimestone, slate, quartz-mica phyllite, and minor quartzite (fig. 3). Poorly preserved conodonts from one area are of late Paleozoic, possibly Mississippian, age (Dusel-Bacon and Harris, 2003). Werdon and others (2001) proposed that the Chicken Metamorphic Complex comprises a volcanic arc upon which the subordinate sediments and limestone were deposited. Similarities in protoliths, arc geochemical signatures of metaigneous rocks, and conodont age ranges of the Chicken Metamorphic Complex and Fortymile River assemblage indicate a shared origin for the two units (Dusel-Bacon and others, 2006). A map unit (Pzg) defined by Foster (1976) to consist of greenstone, with minor greenschist, quartzite, chert, and phyllite was included in the Chicken Metamorphic Complex by Werdon and others (2001). Another large area of unit Pzg was mapped by Foster (1976) northwest of the Taylor Mountain batholith in the Kechumstuk Creek area. We provisionally show these rocks as also being part of the Chicken Metamorphic Complex in figures 3 and 4, based on Foster's mapping.

Proximity of the Fortymile River assemblage to continental basement (either a craton or a rifted continental fragment) is indicated by elevated Th contents in mafic metaigneous rocks, and the geochemical similarity of elemental ratios in felsic metaigneous rocks to those in average upper continental crust, as well as by a minor amount of Proterozoic inheritance in zircons from felsic metaigneous rocks (Dusel-Bacon and others, 2006). Detrital zircons from a $0.5 \mathrm{~m}$ section of core from a subarkosic quartzite in the Fish prospect (fig. 5), presumably part of the Fortymile River assemblage, yield a range of $\mathrm{U}-\mathrm{Pb}$ ages with well-developed populations at 2.8 to $2.55 \mathrm{Ga}$, 2.5 to $1.5 \mathrm{Ga}$, and 1,050 to $550 \mathrm{Ma}$ (Van Wyck, 2007b). These ages are typical of detrital zircons in Paleozoic rocks of cratonal North America and indicate a maximum depositional age of $550 \mathrm{Ma}$ for the Fortymile River assemblage.

Archean and Proterozoic ages also have been determined for detrital and inherited (core) zircons from greenschist- to amphibolite-facies continental-margin assemblages in the western Yukon-Tanana Upland and the Alaska Range (green map unit on fig. 1; Continental Margin Assemblages on fig. 2). These continental-margin strata were intruded by bimodal Late Devonian to Early Mississippian igneous rocks having within-plate geochemical signatures, interpreted by Dusel-Bacon and others (2006, and references therein) to have formed during attenuation of the continental margin. Klippe of weakly metamorphosed oceanic rocks of the Slide Mountain and Seventymile terranes (figs. 1 and 2) tectonically 
overlie, or are imbricated with, the higher-grade metamorphic rocks. A number of studies have addressed the genetic and tectonic relations among the above-described continental-margin assemblages, the arc and basinal assemblages, and the oceanic terranes. An equally important question is the relationship of those tectonic elements to the ancient continental margin of North America, from which they are separated by the Tintina dextral strike-slip fault or, in the Finlayson Lake area in southeastern Yukon (fig. 1), by thrust faults along the eastern margin of a structurally complex fragment composed of arc, basinal, and oceanic rocks (Colpron and others, 2006; Murphy and others, 2006).

Although the deformed character, poor exposure, and similarity of many rock types in the various assemblages will likely always result in differing interpretations of their history, the following geologic scenario is proposed, building on decades of multidisciplinary and collaborative research (see summaries in Dusel-Bacon and others, 2006; Nelson and others, 2006; Piercey and others, 2006; Colpron and others, 2006). Initially, a prolonged, Devonian to Mississippian, synmagmatic extensional episode occurred in a broad arc and back-arc region associated with an east-dipping subduction zone. This attenuation of the continental margin produced the Slide Mountain-Seventymile ocean basin and rifting of an outboard fragment of the continental margin and its overlying mid-Paleozoic arc cover (including the Fortymile River and Nasina assemblages and Chicken Metamorphic Complex). Subsequent closure of the Slide Mountain-Seventymile ocean basin began during mid-Permian time as a result of west-dipping subduction, and continued as the outboard rifted fragment was obducted onto, and imbricated with, the continental margin (including the parautochthonous continental-margin assemblages and their within-plate intrusions, shown in green on figure 1) in Triassic and Jurassic time (Hansen and others, 1991; Dusel-Bacon and others, 2002). Permian, Late Triassic, and Early Jurassic arc plutons intrude only the allochthonous, obducted, and originally outboard arc assemblages.

The parautochthonous continental-margin assemblage and much of the Devonian-Mississippian and Permian arc assemblages (orange and pale blue, respectively, on figure 1) in Alaska and adjacent Yukon were originally defined as the Yukon-Tanana terrane by Coney and others (1980). Subsequent studies redefined it as a composite terrane in recognition of differences in composition, origin, and structural and metamorphic histories (for example, Foster and others, 1985; Hansen and others, 1991; Mortensen, 1992; Dusel-Bacon and Cooper, 1999). Nelson and others (2006) proposed retaining the term Yukon-Tanana terrane for only the arc and back-arc components of the alloch- thonous composite terrane (fig. 1), and refer to the continental-margin components in Alaska as parautochthonous North America. However, use of this terrane name for only the allochthonous part of the originally defined tectonic terrane can be confusing; therefore, we follow the recommendation of Dusel-Bacon and others (2006) and refer to the specific geologic assemblages and avoid use of terrane terminology.

\section{Mesozoic Magmatism in the South- ern Eagle Quadrangle}

\section{Magmatic Episodes}

Late Triassic, Early Jurassic, and, rarely, Cretaceous intrusions have been mapped in the southern Eagle quadrangle (Foster, 1976; Werdon and others, 2001; Szumigala and others, 2002). Most of the igneous rocks in this region have been dated by the ${ }^{40} \mathrm{Ar} /{ }^{39} \mathrm{Ar}$ thermochronometer (Cushing, 1984; Newberry and others, 1998b; Dusel-Bacon and others, 2002; Werdon and others, 2001; Szumigala and others, 2002), which provides a cooling history based on closure temperatures of $450 \pm 50^{\circ} \mathrm{C}$ for hornblende (Baldwin and others, 1990), $375 \pm 25^{\circ} \mathrm{C}$ for muscovite (Hunziker and others, 1992), and $300 \pm$ $50^{\circ} \mathrm{C}$ for biotite (Harrison and others, 1985). All of these ${ }^{40} \mathrm{Ar} /{ }^{39} \mathrm{Ar}$ ages are important in determining the intermediate-temperature portion of the cooling and uplift history of the plutons, but U-Pb dating of zircon from these plutons provides a higher temperature crystallization age that better approximates the timing of emplacement because the closure temperature of zircon is in excess of $900^{\circ} \mathrm{C}$ (for example, Heaman and Parrish, 1991). In plutonic rocks where no zircon is present, $\mathrm{U}-\mathrm{Pb}$ ages on accessory titanite provide a closure temperature of approximately $660-700^{\circ} \mathrm{C}$ (Scott and St-Onge, 1995).

Table 1 presents the new $\mathrm{U}-\mathrm{Pb}$ ages and sample descriptions of the three igneous samples that were analyzed by Aleinikoff in our study of the Mount Veta area (sample identification numbers 1-3), as well as zircon and titanite ages from other Triassic and Jurassic bodies that were determined by Mortensen during previous regional studies in the southern Eagle quadrangle (Dusel-Bacon and others, 1995, 2002). Published ${ }^{40} \mathrm{Ar}^{-39} \mathrm{Ar}$ ages for samples from, or near, these localities, and two additional $\mathrm{U}-\mathrm{Pb}$ zircon ages, also are shown in table 1 . U-Pb zircon ages determined by Aleinikoff, described below, derive from analyses of multiple spots on single zircon grains using a sensitive high-resolution ion microprobe with reverse-geometry (SHRIMP-RG) instrument. U-Pb 


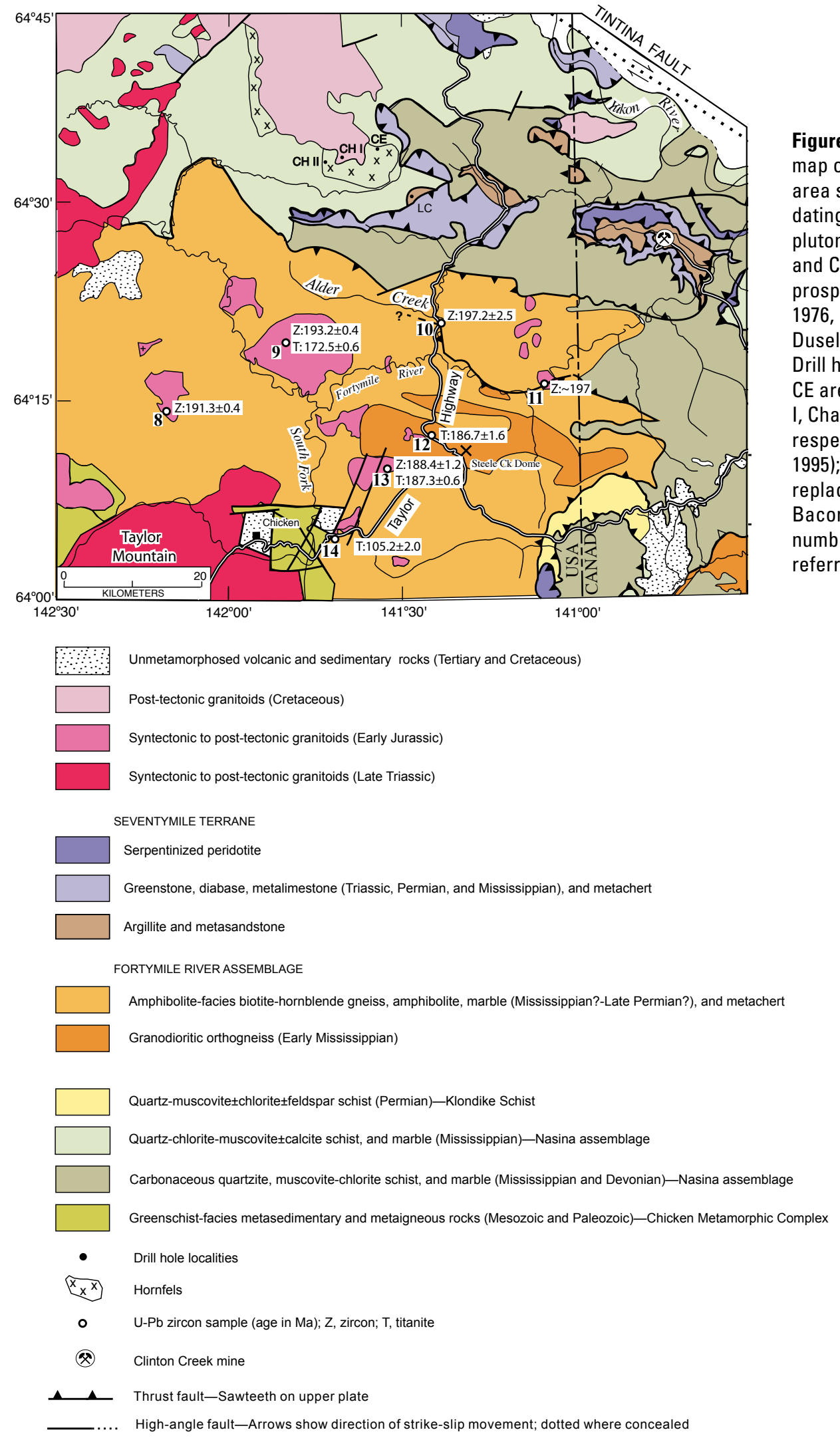


zircon and titanite ages determined by Mortensen were done at the Pacific Centre for Isotopic and Geochemical Research at the University of British Columbia, by thermal-ionization mass spectrometric (TIMS) analyses of multigrain zircon or titanite fractions (for methodology, see Mortensen and others, 1995)The Late Triassic and Early Jurassic plutons are generally of intermediate composition and are slightly foliated or gneissic, particularly along their margins (Foster and others, 1994; Werdon and others, 2001; Szumigala and others, 2002). Some of the
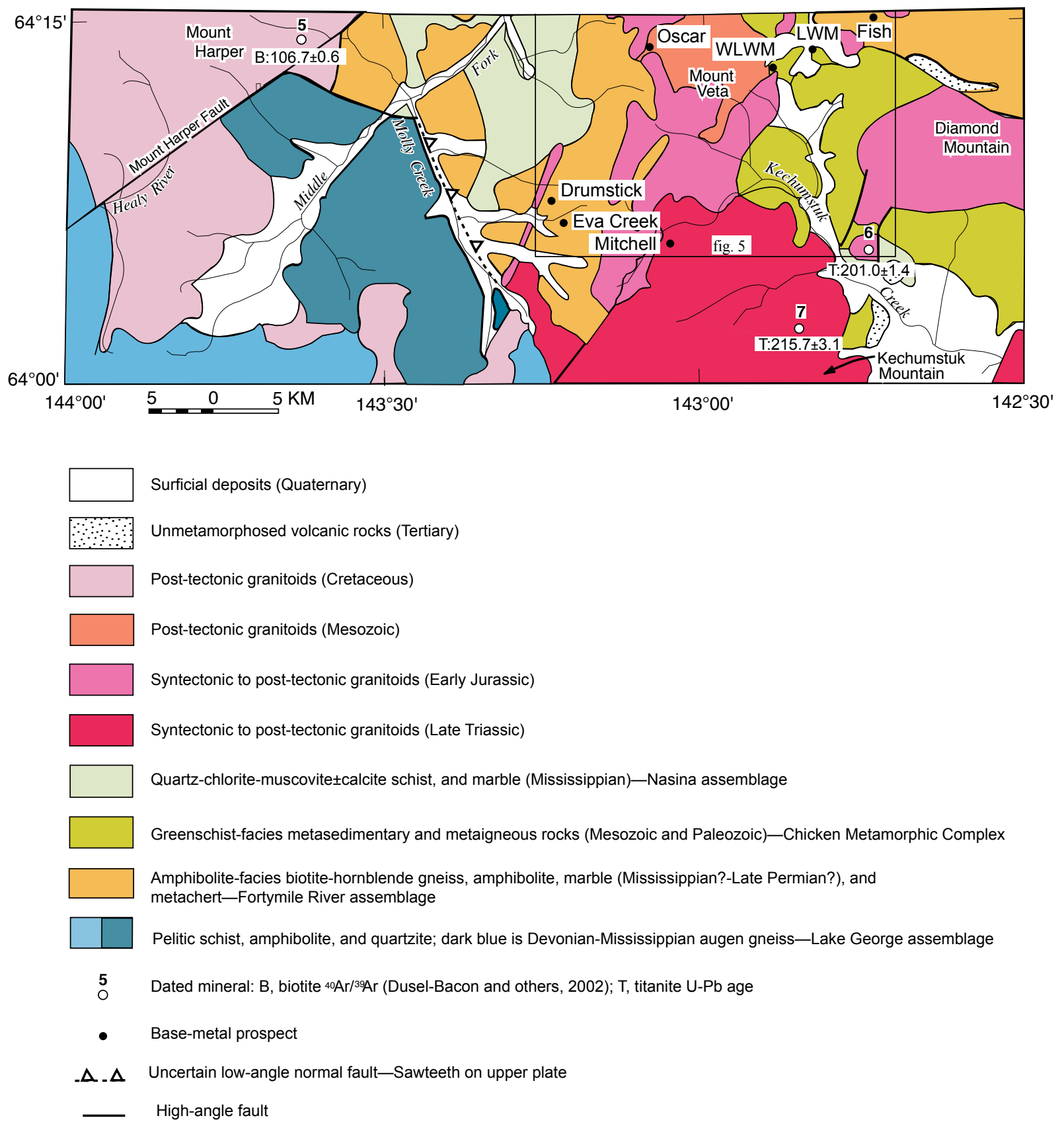

Figure 4. Simplified geologic map of the southwestern part of the Eagle quadrangle showing locations of base-metal occurrences and selected igneous crystallization ages (in Ma). Geology modified from Foster (1992). Sample numbers next to U-Pb ages are referred to in tables 2 and 3. LWM, Little Whiteman prospect; WLWM, West Little Whiteman prospect. 
weak mineral alignment may be magmatic, but the local development of shearing along some pluton margins and the presence of strained and granulated quartz in some samples indicates synkinematic intrusion of these plutons. Day and others $(2000,2002)$ mapped two bodies, two to three kilometers in length along the Fortymile River north of Chicken, composed of weakly to moderately foliated, biotite leucogranite to trondhjemite and late-stage dikes. They concluded that the moderate to weak tectonic foliation and absence of lineation in the leucogranite and trondhjemite bodies indicate that they were unaffected by, and thus postdate, the most intense, $\mathrm{D}_{1}$ deformational event that formed prominent lineations in rocks of the Fortymile River assemblage. Day and others further proposed that the bodies intruded during the waning stages of $\mathrm{a} \mathrm{D}_{2}$ deformational event. A zircon U-Pb age of $196 \pm 4$ $\mathrm{Ma}$, determined for an epidote-bearing biotite leucogranite from one of these bodies by SHRIMP-RG, establishes the timing for the waning phase of the $\mathrm{D}_{2}$ deformational event (Day and others, 2002).

Late Triassic plutons in the region include the $\sim 212$ Ma Taylor Mountain batholith (sample 15; fig. 2, table 1) that comprises quartz monzodiorite, tonalite, granodiorite, and quartz diorite (Werdon and others, 2001);

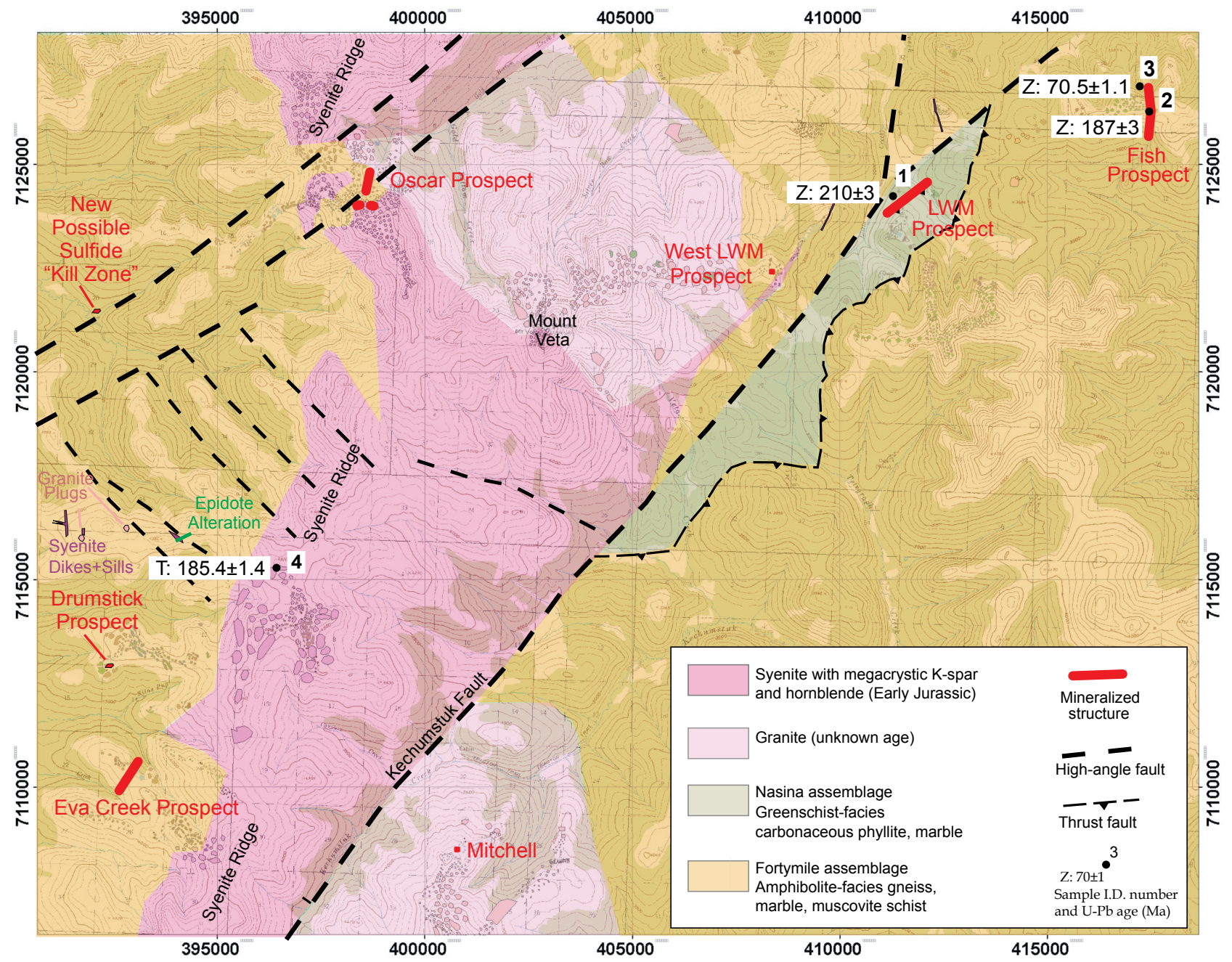

Figure 5. Geologic compilation of part of the Fortymile project area being explored by Full Metal Minerals, USA, Inc., showing locations of base-metal prospects and mapped faults (modified from Cooley, 2007) and U-Pb zircon ages (this study); Z, zircon; T, titanite. Sample numbers next to U-Pb ages are referred to in tables 1-3. Green pattern on underlying topographic base depicts areas of vegetation. Darker colored patches within colored units show areas of outcrop and subcrop. UTM coordinates and grid shown on map are those for zone $7 \mathrm{~N}$ of the NAD 83 datum. 

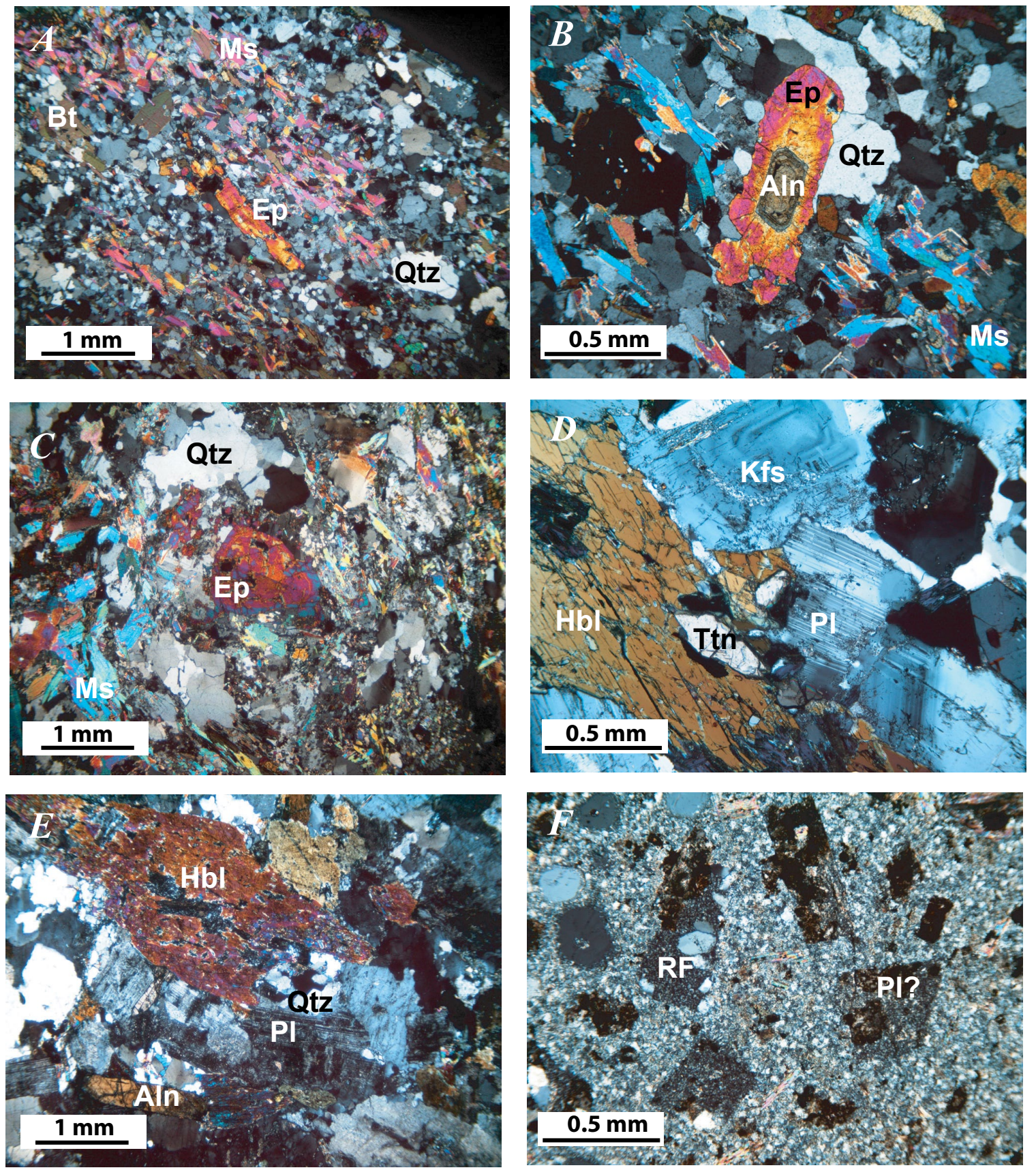

Figure 6. Representative photomicrographs of selected igneous rocks in the Fortymile district for which new U-Pb ages are reported (this study). All images were taken with transmitted, cross-polarized light. $A$, Epidote-bearing granodiorite (sample 11, table 1, fig. 3) showing preferred orientation of epidote (Ep), muscovite (Ms), and biotite (Bt) grains. $B$, Same sample as in A showing allanite (Aln) core within epidote crystal. C, Epidote-bearing granodiorite (sample 10, table 1, fig. 3) showing zoning of euhedral epidote grain (note blue birefringent rim). D, Hornblende quartz diorite (sample 1, table 1, fig. 5) showing hornblende ( $\mathrm{Hbl}$ ), concentrically zoned K-feldspar (Kfs), polysynthetic twinned plagioclase (PI), and doubly terminated accessory titanite (Ttn) grain. $E$, Hornblende quartz monzonite (sample 2, table 1, fig. 5) showing weakly developed preferred orientation of hornblende and plagioclase phenocrysts and tabular allanite and polygonized quartz (Qtz) grains. F, Altered rhyolite porphyry (sample 3, table 1, fig. 5) showing quartz, muscovite, and Fe-stained altered plagioclase(?) phenocrysts, and rock fragment (RF) in a fine-grained matrix of quartz, feldspar, phyllosilicate, and Fe-Ti oxide. 
Table 1. New U-Pb ages and descriptions of Mesozoic igneous samples from the Fortymile area, Alaska.

[Mineral abbreviations: Aln, allanite; Ap, apatite; Bt, biotite; Cal, calcite; Chl, chlorite; Cpx, clinopyroxene; Czo, clinozoisite; Ep, epidote; Fs, feldspar; Grt, garnet; Hbl, hornblende; Kfs, K- feldspar; Ms, muscovite; Pl, plagioclase; Otz, quartz; Ser, seriite; Ttn, titanite; Zo, zoisite; Zrn, zircon. Unit abbreviations: Jg, Jurassic granitoid; Kg, Cretaceous granitoid; Krhy, Cretaceous rhyolite porphyry; Trg, Triassic granitoid. Quadrangle abbreviations: EA, Eagle; TA, Tanacross.
LWM, Little White Man prospect]

\begin{tabular}{|c|c|c|c|c|c|c|c|c|}
\hline $\begin{array}{l}\text { I.D. number } \\
\text { (figure) }\end{array}$ & Sample & Rock type & Geologic unit & $\mathrm{U}-\mathrm{Pb}$ date $(\mathrm{Ma})$ & $\begin{array}{l}\text { U-Pb Geochronologist; description of } \\
\text { data or published source. }{ }^{40} \mathrm{Ar} r^{39} \mathrm{Ar} \text { age } \\
\text { (Ma), if available. }\end{array}$ & Quadrangle & $\begin{array}{l}\text { Latitude and } \\
\text { longitude }\end{array}$ & $\begin{array}{l}\text { Pluton; petrography (minerals listed in decreasing } \\
\text { abundance) }\end{array}$ \\
\hline 1 (fig. 5) & $\begin{array}{l}\text { LWM-07-06- } \\
124\end{array}$ & Hbl Qtz diorite & $\operatorname{Trg}$ & Zrn: $210 \pm 3$ & J.N. Aleinikoff; this paper & EAA-4 & $\begin{array}{l}64^{\circ} 14^{\prime} 07^{\prime \prime} \\
142^{\circ} 49^{\prime} 37^{\prime \prime}\end{array}$ & $\begin{array}{l}\text { LWM drill core. Highly altered, medium-grained, Hbl- } \\
\text { bearing intermediate-composition granitoid. Pl and } \\
\text { Kfs(?) locally preserve relict zoning and are intensely } \\
\text { sericitized or, less commonly, kaolinitized. Hbl is mostly } \\
\text { altered to Chl (with anomalous purple bf.) and } \\
\text { intergrown with elongate masses of fine-grained granular } \\
\text { Ttn; scattered patches of yellow Ep appear to be an } \\
\text { alteration product and not primary. Qtz is strained. } \\
\text { Weak alignment of elongate minerals and preferred } \\
\text { orientation of Qtz; unclear whether alignment is a } \\
\text { primary magmatic fabric or a weakly developed, } \\
\text { superimposed metamorphic fabric. Accessory minerals: } \\
\text { scattered Ttn (up to 3-mm-long). Aln. Ap. Zrn. }\end{array}$ \\
\hline 2 (fig. 5) & 07ADb01A & $\begin{array}{l}\text { Hbl Qtz } \\
\text { monzonite }\end{array}$ & $\mathrm{Jg}$ & Zrn: $187 \pm 3$ & J.N. Aleinikoff; this paper & EA B-4 & $\begin{array}{l}64^{\circ} 15.408^{\prime} \\
142^{\circ} 42.001^{\prime}\end{array}$ & $\begin{array}{l}\text { Pluton at Fish prospect. Hypidiomorphic, granular, } \\
\text { medium-grained, Hbl Qtz monzonite. Phenocrysts of } \\
\mathrm{Hbl}, \mathrm{Pl} \text {, and } \mathrm{Kfs} \text {; all reach about } 3 \mathrm{~mm} \text { in maximum } \\
\text { length; many Pl and Kfs grains (present in approximately } \\
\text { equal amounts) display polysynthetic twinning and are } \\
\text { moderately kaolinitized. Interstitial Qtz }(\sim 10 \%) \text { also } \\
\text { reaches } 3 \text { mm in diameter and forms fractured and } \\
\text { polygonized grains. Concentration of fine-grained Ep } \\
\text { between Hbl and altered Pl Accessory Fe-Ti oxide, Ttn, } \\
\text { Zrn, Ap, and Aln. }\end{array}$ \\
\hline 3 (fig. 5) & Fish06-04-35 & $\begin{array}{l}\text { altered rhyolite } \\
\text { porphyry }\end{array}$ & Krhy & Zrn: $70.5 \pm 1.1$ & J.N. Aleinikoff; this paper & EA B-4 & $\begin{array}{l}64^{\circ} 15^{\prime} 39^{\prime \prime} \\
142^{\circ} 42^{\prime} 17^{\prime \prime}\end{array}$ & $\begin{array}{l}\text { Fish drill core. Sparsely Qtz porphyritic rhyolite with } \\
\text { phenocrysts of Qtz, Ms, and Fe-Ti oxide or Fe carbonate } \\
\text { after Fs. Rare incorporated rock fragments and a rapakivi } \\
\text { alkali feldspar rimmed by Pl (xenocryst from Mount Veta } \\
\text { intrusion?); } 1 \mathrm{~mm} \text { thick carbonate veinlet. }\end{array}$ \\
\hline
\end{tabular}
Qtz monzonite others, 2002; two concordant titanites at $\quad 143^{\circ} 07^{\prime} 36^{\prime \prime}$ 185.4 1.4 Ma. Zircons have abundant inheritance (upper intercept age of $\sim 1.76 \mathrm{Ga}$ ) but are consistent with this age.

5 (fig. 4) $\quad 91 \mathrm{ADb} 26 \quad \begin{aligned} & \text { Mount Harper } \quad \mathrm{Kg} \\ & \text { Bt-Hbl Qtz }\end{aligned}$ Bt-Hbl Qtz $10 \%$ of rock and euhedral Ttn, myrmekite, and patches of coarse, polycrystalline $\mathrm{Cal}$ is present in trace amounts. $\mathrm{Hbl}$ is green and exceptionally fresh; alteration of some $\mathrm{Pl}$ grains to Ser and in a few grains of $\mathrm{Hbl}$ to $\mathrm{Chl}$. Hypidiomorphic, granular texture. Qtz has weakly Hypidiomorphic, granular texture. Qzz has weakly
undulose or, less commonly, uniform extinction. undulose or, less commonly, uniform extinction.
Fine-grained Kfs-Pl-Bt-Hbl Qtz monzonite. Qtz $\sim 10 \%$ ${ }^{40} \mathrm{Ar}{ }^{39} \mathrm{Ar}: 106.7 \pm 0.6$ on Bt; Dusel- $\quad$ EA A- 6 $64^{\circ} 14^{\prime} 03^{\prime \prime}$

$43^{\circ} 38^{\prime} 12^{\prime \prime}$ trace amounts of opaque minerals and Ap. Largest and most euhedral $\mathrm{Bt}$ is dark brown; finer grained dark brown $\mathrm{Bt}$ is locally altered to green $\mathrm{Bt}$ along cleavage planes and around grain margins; $\mathrm{Hbl}$ forms bright green irregular-shaped masses that are commonly altered to $\mathrm{Ep}$ or green $\mathrm{Bt}$; Fs shows patchy kaolinitization. Qtz has uniform or weakly undulose extinction.

\begin{tabular}{|c|c|c|c|c|c|c|}
\hline 6 (fig.4) & 93ADb09 & $\begin{array}{l}\text { Hbl-Bt } \\
\text { granodiorite }\end{array}$ & $\mathrm{Jg}$ & Ttn: $201.0 \pm 1.4$ & $\begin{array}{l}\text { J.K. Mortensen. } 40 \mathrm{Ar} / 39 \mathrm{Ar}: 197.3 \pm 0.7 \\
\text { Hbl; Newberry and others, } 1998 \mathrm{~b}\end{array}$ & EA A-4 \\
\hline 7 (fig. 4) & $93 \mathrm{ADb} 10$ & $\begin{array}{l}\text { Hbl-Bt } \\
\text { granodiorite }\end{array}$ & $\operatorname{Trg}$ & Ttn: $215.7 \pm 3.1$ & $\begin{array}{l}\text { J.K. Mortensen, in Dusel-Bacon and } \\
\text { others, 2002; two concordant titanites }\end{array}$ & EA A- 4 \\
\hline 8 (fig. 3) & $93 \mathrm{ADb} 18$ & $\begin{array}{l}\text { garnetiferous 2- } \\
\text { mica granite }\end{array}$ & $\mathrm{Jg}$ & Zrn: $191.3 \pm 0.4$ & $\begin{array}{l}\text { J.K. Mortensen, in Dusel-Bacon and } \\
\text { others, } 2002 \text {; of four zircons analyzed, } \\
\text { three have abundant inheritance and one } \\
\text { is concordant at } 191.4 \pm 0.4 \mathrm{Ma} \text {. Upper } \\
\text { intercept age of } 2.44 \mathrm{Ga} \text {. }\end{array}$ & EAA-3 \\
\hline 9 (fig. 3) & $98 \mathrm{ADb} 30$ & $\begin{array}{l}\mathrm{Hbl} \\
\text { monzodiorite }\end{array}$ & $\mathrm{Jg}$ & $\begin{array}{l}\text { Zrn: } 193.2 \pm 0.4 \\
\text { Ttn: } 172.5 \pm 0.6\end{array}$ & J.K. Mortensen & EA B-2 \\
\hline 10 (fig.3) & $00 \mathrm{ADb} 41$ & $\begin{array}{l}\text { Qtz-Ms-Bt-Ep } \\
\text { granodiorite }\end{array}$ & $\mathrm{Jg}$ & Zrn: $197.2 \pm 2.5$ & $\begin{array}{l}\text { J.K. Mortensen; analyzed very small } \\
\text { fractions of strongly abraded tips } \\
\text { broken off grains with cloudy cores. } \\
\text { Five fractions were analyzed: two are } \\
\text { concordant with a total range of } \\
{ }^{206} \mathrm{~Pb} /{ }^{238} \mathrm{U} \text { ages of } 194.6-199.5 \mathrm{Ma} ; \\
\text { component of inherited Zrn. The five } \\
\text { fractions form a reasonably well } \\
\text { constrained regression with an upper } \\
\text { intercept age of } 2.45 \mathrm{Ga} \text {. }\end{array}$ & EA B-1 \\
\hline
\end{tabular}

64.08'32"; $\quad$ Pluton of Diamond Mountain. Medium-grained Pl-Qtz$142^{\circ} 40^{\prime} 58^{\prime \prime} \quad$ Hbl-Kfs-Bt granodiorite. Trace amounts of Fe-Ti oxide, Hbl-Kfs-Bt granodiorite. Trace amounts of Fe-Ti oxide,
Ttn, and Zrn. Local, minor alteration of $\mathrm{Hbl}$ and Bt to Ttn, and Zrn. Local, minor alteration of Hbl and Bt to
Chl or Ep, and Fs to Ser. No detectable preferred fabric. Pluton of Kechumsktuk Mountain. Medium-grained PlQtz-Hbl-Kfs-Bt granodiorite. Trace amounts of $\mathrm{Fe}-\mathrm{Ti}$ oxide, Ttn, and Zrn. Local, minor alteration of $\mathrm{Hbl}$ and $\mathrm{Bt}$ to $\mathrm{Chl}$ or $\mathrm{Ep}$, and Fs to Ser. No detectable preferred fabric.

64'14'24"; Mount Warbelow pluton. Highly altered and deformed $142^{\circ} 11^{\prime} 50^{\prime \prime} \quad$ Ms-Bt-Otz-Ksp-Pl granite with accessory Grt. Alteration assemblage of Ser, $\mathrm{Zo} / \mathrm{Czo}$, fine-grained granular Ttn, assemblage of Ser, $\mathrm{Zo} / \mathrm{Czo}$, fine-grained granular Ttn,
and Cal primarily developed within relict Pl. Qtz highly strained with sutured grain boundaries. Metamorphic fabric defined by alignment of micas and Qtz grain boundaries.

$64^{\circ} 20^{\prime} 07^{\prime \prime} ; \quad$ Pig pluton. Medium-grained Pl-Hbl-Cpx monzodiorite; Dark green $\mathrm{Hbl}$ up to $2 \mathrm{~mm}$ in length; some $\mathrm{Cpx}$ rimmed by $\mathrm{Hbl}$; Qtz $<5 \%$; minor amount of anhedral, interstitial Ep along some $\mathrm{Hbl}$ margins (associated with partly altered Fs); minor Bt associated with or after Hbl; very minor Kfs; trace of Ap. Hypidiomorphic granular minor $\mathrm{K}$
texture.

$64^{\circ} 21^{\prime} 12.6^{\prime \prime} ; \quad$ Foliated Qtz-Ms-Bt-P1-Ep granodiorite. Many Bt grains $141^{\circ} 24^{\prime} 0^{\prime \prime} \quad$ altered to Chl. Minor Zo/Czo and trace of accessory Zrn and Ttn, and secondary Cal. Ep comprises $\sim 7 \%$ of rock; many Ep grains are zoned. Oxide grains rare. Strained, polygonized Qtz with sutured margins. 
Table 1. New U-Pb ages and descriptions of Mesozoic igneous samples from the Fortymile area, Alaska-Continued.

\begin{tabular}{|c|c|c|c|c|c|c|c|c|}
\hline $\begin{array}{l}\text { I.D. number } \\
\text { (figure) }\end{array}$ & Sample & Rock type & Geologic unit & $\mathrm{U}-\mathrm{Pb}$ date $(\mathrm{Ma})$ & $\begin{array}{l}\text { U-Pb Geochronologist; description of } \\
\text { data or published source. }{ }^{40} \mathrm{Ar}{ }^{39} \mathrm{Ar} \text { age } \\
\text { (Ma), if available. }\end{array}$ & Quadrangle & $\begin{array}{l}\text { Latitude and } \\
\text { longitude }\end{array}$ & $\begin{array}{l}\text { Pluton; petrography (minerals listed in decreasing } \\
\text { abundance) }\end{array}$ \\
\hline 11 (fig. 3) & 00ADb18 & $\begin{array}{l}\text { Bt-Ep-Ms } \\
\text { granodiorite }\end{array}$ & $\mathrm{Jg}$ & Zrn: 197 & $\begin{array}{l}\text { J.K. Mortensen; analyzed four Zrn } \\
\text { fractions: confirms an age of } \sim 197 \mathrm{Ma}\end{array}$ & EA B-1 & $\begin{array}{l}64^{\circ} 16^{\prime} 03.2^{\prime \prime} ; \\
141^{\circ} 05^{\prime} 40.2^{\prime \prime}\end{array}$ & $\begin{array}{l}\text { Foliated fine-grained Bt-Ep-Qtz-Ms-Pl granodiorite. Pl } \\
\text { phenocrysts up to } 0.5 \mathrm{~cm} \text { in length. Ep and Zo together } \\
\text { comprise } ~ 7 \% \text { of rock; Aln cores occur within both Ep } \\
\text { and Zo. Foliation defined by discontinuous } \\
\text { compositional banding of Ms and Qtz and weakly } \\
\text { developed preferred orientation of some Ep grains. } \\
\text { Many of the Bt books are associated with clots of Ep. Pl } \\
\text { is rarely twined and contains dusting of Ser or other } \\
\text { minute inclusions. Oxide grains rare. }\end{array}$ \\
\hline 12 (fig. 3) & $98 \mathrm{ADb} 15$ & $\begin{array}{l}\text { Bt-Hbl } \\
\text { granodiorite }\end{array}$ & $\mathrm{Jg}$ & Ttn: $186.7 \pm 1.6$ & J.K. Mortensen & EA A-1 & $\begin{array}{l}64^{\circ} 12^{\prime} 00^{\prime \prime} \\
141^{\circ} 24^{\prime} 39^{\prime \prime}\end{array}$ & $\begin{array}{l}\text { Bt-Hbl granodiorite with moderately common zoned } \mathrm{Kfs} \\
\text { phenocrysts } \sim 1 \mathrm{~cm} \text { long; Kfs is perthitic and commonly } \\
\text { has mymekite margins. Abundant } \mathrm{Pl} \text {; greenish-brown } \mathrm{Bt} \\
\text { and green } \mathrm{Hbl} \text { present in equal amounts. Minor, Ttn, Ep, } \\
\mathrm{Czo} / \mathrm{Zo} \text { and Aln ( } 1 \text { Aln crystal rimmed by Zo). Minor } \\
\text { alteration of Bt to Chl. Subparallel alignment of elongate } \\
\text { minerals with clearly igneous habit and mineralogy } \\
\text { suggests magmatic flow foliation. }\end{array}$ \\
\hline 14 (fig.3) & $93 \mathrm{ADb} 37$ & $\begin{array}{l}\text { Bt-Hbl } \\
\text { granodiorite }\end{array}$ & $\mathrm{Kg}$ & Ttn: $105.2 \pm 2.0$ & $\begin{array}{l}\text { J.K. Mortensen; one concordant titanite. } \\
{ }^{40} \mathrm{Ar}{ }^{39} \mathrm{Ar}: 100 \mathrm{Bt} \text { (Werdon and others, } \\
{ }^{2001)}\end{array}$ & EAA-2 & $\begin{array}{l}64^{\circ} 05^{\prime} 17^{\prime \prime} \\
141^{\circ} 39^{\prime} 04^{\prime \prime}\end{array}$ & $\begin{array}{l}\text { Walker Fork pluton. Medium-grained, hypidiomorphic } \\
\text { granular Bt-Pl-Ksp-Qtz-Hbl granodiorite. Trace amounts } \\
\text { of Fe-Ti oxide, allanite (up to } 1 \mathrm{~mm} \text { in length), Ttn, Ap, } \\
\text { And Zr. } \sim 1 \mathrm{~mm} \text { biotite grains distinctive. Local alteration } \\
\text { of mafic minerals to Chl and Ep, and feldspars to sericite. }\end{array}$ \\
\hline 15 (fig.2) & 93ADb01 & $\begin{array}{l}\text { Hbl-Bt quartz } \\
\text { monzodiorite }\end{array}$ & $\operatorname{Trg}$ & $\begin{array}{l}\text { Ttn: } 212 \text { age } \\
\text { nearby }\end{array}$ & $\begin{array}{l}\text { Aleinikoff and others, } 1981 .{ }^{40} \mathrm{Ar} /{ }^{39} \mathrm{Ar} \text { : } \\
209 \mathrm{Hbl} \text { and } 204 \mathrm{Bt} \text { (Cushing, } 1984) ; \\
210-211 \mathrm{Hbl} \text { (Werdon and others, 2001) } \\
\text { from same intrusion. }\end{array}$ & TA D-3 & $\begin{array}{l}63^{\circ} 59^{\prime} 35^{\prime \prime} \\
142^{\circ} 10^{\prime} 50^{\prime \prime}\end{array}$ & $\begin{array}{l}\text { S. margin Taylor Mtn. batholith. Medium-grained Pl-Kfs- } \\
\text { Hbl-Bt quartz monzodiorite. Trace amounts of Fe-Ti } \\
\text { oxide, Ttn, Aln, and Zrn. Secondary Ep locally replaces } \\
\text { the margins of Hbl or Bt. No detectable preferred fabric. }\end{array}$ \\
\hline
\end{tabular}

the $\sim 216$ Ma pluton of Kechumstuk Mountain (sample 7, fig. 4 , table 1) with a similar compositional range (Foster and others, 1978); and the Happy granite (fig. 2), whose intrusive age is assumed to be close to that of a $214 \mathrm{Ma}$ ${ }^{40} \mathrm{Ar} /{ }^{39} \mathrm{Ar}$ age of muscovite from a vein that cuts the pluton (Newberry and others, 1998b).

$\mathrm{U}-\mathrm{Pb}$ zircon and titanite ages for the subsequently intruded plutons range from Early Jurassic (185 Ma; table 1, figs. 3 and 5) to the Late Triassic-Early Jurassic boundary $(201 \pm 1.4 \mathrm{Ma}$; sample 6 , table 1 , fig. 4$)$. A number of these bodies east of Taylor Mountain have been mapped in detail and dated by the ${ }^{40} \mathrm{Ar} /{ }^{39} \mathrm{Ar}$ method (Werdon and others, 2001; Szumigala and others, 2002). Compositions generally range from granodiorite to monzonite or granite. The $185.4 \pm 1.4$ Ma syenite of Mount Veta (sample 4, table 1, fig. 5) is texturally and compositionally distinctive in that it contains megacrystic K-feldspar within a hornblende \pm quartz matrix; other phases in the pluton include quartz monzonite and diorite (Foster, 1976).

Several of the Early Jurassic plutons contain magmatic epidote. Werdon and others (2001) described magmatic epidote in the moderately foliated to unfoliated biotite-hornblende granodiorite and minor quartz monzodiorite that constitute their Uhler Creek pluton (the body shown between sample numbers 9 and 13, fig. 3). Horn- blende from the Uhler Creek pluton yields a ${ }^{40} \mathrm{Ar} /{ }^{39} \mathrm{Ar}$ plateau age of $188 \mathrm{Ma}$. One of the lines of evidence that Werdon and others (2001) cited for a magmatic origin of epidote in this pluton is the presence of epidote overgrowths on allanite. Equant, subhedral grains of epidote also occur in the $196 \pm 4$ Ma biotite leucogranite of Day and others (2002) mentioned above. The leucogranite is present within a body of foliated, peraluminous biotitemuscovite granodiorite, granite, and trondhjemite along the Fortymile River near the Alaska-Yukon border (Day and others, 2002).

We herein present descriptions and TIMS U-Pb zircon ages for two new occurrences of Early Jurassic magmatic epidote-bearing plutonic rocks, collected by Dusel-Bacon and Mortensen in 2000. The first, a foliated, fine-grained, biotite-epidote-quartz-muscovite-plagioclase granodiorite (sample 11, table 1, fig. 3), was collected along the Fortymile River, about $1 \mathrm{~km}$ west (upstream) of the 196 Ma epidote-bearing biotite leucogranite described above, and likely is from the same body. Plagioclase phenocrysts reach as much as $0.5 \mathrm{~cm}$ in length. Foliation is defined by discontinuous compositional banding of muscovite and quartz, and by a weakly developed preferred orientation of some epidote grains (fig. $6 \mathrm{~A}$ ). Epidote and zoisite together make up $\sim 7$ percent of the thin section. 
Allanite cores occur within some epidote and zoisite grains (fig. 6B). The mantling of allanite by epidote is considered characteristic of magmatic epidote (Zen and Hammarstrom, 1984; Schmidt and Poli, 2004, and references therein). Zircons from sample 11 yield a $\mathrm{U}-\mathrm{Pb}$ age of $\sim 197 \mathrm{Ma}$ (table 1). The second occurrence, approximately $17 \mathrm{~km}$ to the northwest (sample 10, table 1 , fig. 3), is a foliated quartz-muscovite-biotite-plagioclase-epidote granodiorite collected from an outcrop just east of the Taylor Highway, along a dirt road south of Dome Creek. Epidote grains make up approximately 7 percent of the thin section, are commonly zoned (fig. $6 \mathrm{C}$ ), and measure as much as $2 \mathrm{~mm}$ in diameter. Zoisite and clinozoisite are present in minor amounts; zircon and titanite are accessory minerals. Secondary chlorite after green-brown biotite is common, and calcite is sparsely developed. Zircons yield a $\mathrm{U}-\mathrm{Pb}$ age of $197.2 \pm 2.5 \mathrm{Ma}$ (table 1), which is indistinguishable from the $196 \pm 4 \mathrm{Ma}$ age determined for the epidote-bearing leucogranite by Day and others (2002).

As pointed out in previous interpretations of epidotebearing rocks in the southeastern Eagle quadrangle (Werdon and others, 2001; Day and others, 2002), the presence of probable magmatic epidote in those bodies indicates emplacement of the host plutons at mesozonal depths. Studies have shown that magmatic epidote forms at a minimum pressure of $0.5 \mathrm{GPa}$, corresponding to depths of at least $15 \mathrm{~km}$ (Zen and Hammarstrom, 1984; Hammarstrom and Zen, 1992; Schmidt and Poli, 2004, and references therein). Schmidt and Poli (2004) described a number of variables that result in a wide range of estimated pressures for the magmatic crystallization of epidote, including the melt composition, oxygen fugacity, and the order of epidote in the crystallization sequence of the cooling magma. Textural relations observed in a thin section of sample 11 suggest that crystallization of epidote preceded that of plagioclase, biotite, and quartz. Assuming that these textural relations were not modified during subsolidus crystallization, this suggests a pressure greater than $1.0 \mathrm{GPa}$, according to the proposed pressure estimation scheme of Schmidt and Poli (2004), and would correspond to a depth of more than $30 \mathrm{~km}$. A similar early position of epidote in the crystallization sequence is suggested for sample 10, but textural evidence in that sample is more uncertain due to retrograde alteration of biotite to chlorite. Although no thermobarometry has been performed on samples 10 and 11, thermobarometric analysis of two garnet amphibolites that occur $5 \mathrm{~km}$ south of sample 10 yielded peak pressure and temperature $(\mathrm{P}-\mathrm{T})$ conditions of 1.0 to $1.2 \mathrm{GPa}, 645$ to $715^{\circ} \mathrm{C}$ and 0.75 to 1.0 $\mathrm{GPa}, 555$ to $660^{\circ} \mathrm{C}$; thermobarometric analysis of a garnet-kyanite-staurolite schist $15 \mathrm{~km}$ southwest of sample
11 yielded peak $\mathrm{P}-\mathrm{T}$ conditions of 0.86 to $0.97 \mathrm{GPa}, 665$ to $730^{\circ} \mathrm{C}$ (Dusel-Bacon and others, 1995). ${ }^{40} \mathrm{Ar} /{ }^{39} \mathrm{Ar}$ metamorphic cooling ages for amphibolite and pelitic schist from the Fortymile River assemblage in the eastern part of the Fortymile mining district, within about five to 15 $\mathrm{km}$ of localities 10 and 11, range from 187 to $185 \mathrm{Ma}$ for biotite, 191 to $185 \mathrm{Ma}$ for muscovite, and 204 to $188 \mathrm{Ma}$ for hornblende (Dusel-Bacon and others, 1995, 2002).

Mid-Cretaceous felsic to intermediate-composition intrusions are widespread in much of the Yukon-Tanana Upland (fig. 2) but are rare in the Fortymile River assemblage. The only mid-Cretaceous intrusion mapped within this assemblage is the 105 Ma Walker Fork pluton, just east of the Taylor Mountain batholith (sample 14, table 1, fig. 3). The nearest mid-Cretaceous intrusion to the Mount Veta area prospects of our study area is the 107 Ma Mount Harper batholith (sample 5, table 1, fig. 4). This batholith intrudes augen gneiss of the Lake George assemblage and is separated from the Nasina and Fortymile River assemblages and the Mount Veta intrusion by the Mount Harper lineament, which is a major, steep, northeast-striking fault that accommodated uplift of the Mount Harper block (Newberry and others, 1998b; Dusel-Bacon and Murphy, 2001; Dusel-Bacon and others, 2002). A $69.10 \pm 0.19 \mathrm{Ma}$ rhyolite caldera (fig. 2, stippled unit) is preserved just east of Mount Harper along the Middle Fork of the Fortymile River (Bacon and Lanphere, 1996).

\section{SHRIMP U-Pb Zircon Analyses}

\section{Methods}

Zircons were extracted from rock samples using standard mineral-separation techniques of crushing, pulverizing, a Wilfley table, magnetic separation, and methylene iodide. Pristine individual grains were hand-picked, mounted in epoxy, ground to approximate half-thickness to expose cross-sections of the grains, and polished with 6 $\mu \mathrm{m}$ and $1 \mu \mathrm{m}$ diamond suspensions. Reflected and transmitted light images were obtained using a petrographic microscope, and internal zoning (related to chemical composition) was imaged using cathodoluminescence (CL) on a JEOL 5400LV scanning electron microscope (SEM).

Zircons from three samples were dated by $\mathrm{U}-\mathrm{Pb}$ geochronology using the USGS-Stanford University SHRIMP-RG instrument. Following the methods described in Williams (1998), a primary ion beam (about 4 to $5 \mathrm{nA}$ ) focused to a spot size of about $30 \mu \mathrm{m}$ diameter was used to extract material to a depth of about $1 \mu \mathrm{m}$. Isotopes of interest were measured through five cycles through the mass stations. Zircon standard R33 (419 Ma; 
Black and others, 2004) was used to correct ${ }^{206} \mathrm{~Pb} /{ }^{238} \mathrm{U}$ ages for instrumental mass fractionation. Raw data are reduced using Squid 1 (Ludwig, 2001) and plotted using Isoplot 3 (Ludwig, 2003). U concentrations are considered to be accurate to about \pm 20 percent. $\mathrm{U}-\mathrm{Pb}$ data are plotted on Tera-Wasserburg concordia plots (fig. 7) to allow visual identification of coherent age groups. The age of each sample is determined by calculating the weighted average of individual ${ }^{206} \mathrm{~Pb} /{ }^{238} \mathrm{U}$ ages (Ludwig, 2003). Weighted means of ages are reported with $2 \sigma$ uncertainties. Age data (table 2) are discussed below in chronological order.

\section{Sample Descriptions}

Sample 1 (table 1, fig. 5) is a highly altered, mediumgrained, hornblende-bearing quartz diorite collected from 2007 LWM drill hole 6 at a depth of 124-126 m. Diamond drilling indicates that the diorite has a minimum thickness of $56 \mathrm{~m}$ and is separated from an overlying $>60 \mathrm{~m}$ interval of greenstone by a $\sim 10$-m-thick fault zone (Full Metal Minerals, USA, Inc., 2008). Feldspar in the sample is highly altered, making its petrographic identification difficult. Hornblende is extensively altered to chlorite and is intergrown with elongate masses of fine-grained, granular titanite. Epidote, observed in scattered patches, appears to be secondary, and not a primary magmatic mineral. Accessory minerals include titanite, in 3-mm-long grains, as well as allanite, apatite, and zircon. Strained quartz and a weakly developed preferred orientation of the elongate minerals and quartz subgrains record either syntectonic intrusion or a superimposed tectonometamorphic episode, or both.

Sample 2 (table 1, fig. 5) is a surface sample of medium-grained, hornblende quartz monzonite from the Fish prospect. The sample was collected at the western end of one of several small granitoid bodies mapped by Foster (1976) on the north side of the headwaters of Gold Creek. Plagioclase and K-feldspar are estimated to be present in approximately equal proportions. Quartz is fractured and polygonized. Feldspar and hornblende grains have a weakly developed preferred orientation. Fine-grained epidote occurs between some hornblende and altered plagioclase grains and is not thought to be primary; accessory minerals include Fe-Ti oxide, titanite, zircon, apatite, and allanite.

Sample 3 (table 1, fig. 5) is an altered rhyolite porphyry collected from 2006 Fish drill hole 4 at a depth of 35.8 to $37.0 \mathrm{~m}$. The rhyolite is from a $2-\mathrm{m}$-thick interval that underlies altered and brecciated marble and overlies a sulfide-bearing sequence of pale green silty metacar- bonate, greenstone, and quartzite (Full Metal Minerals, USA, Inc., unpub. data, 2006). The presence of a cluster of quartz phenocrysts $>5 \mathrm{~mm}$ in diameter, observed mesoscopically in drill core, suggests that the rock formed as a lava flow or shallow intrusion. Thin section analysis shows resorbed quartz phenocrysts as much as $4 \mathrm{~mm}$ in diameter, and smaller ( 1-mm-diameter) phenocrysts of quartz, muscovite, and Fe-Ti oxide or iron carbonate after feldspar, within a fine-grained felsic groundmass. Rare incorporated rock fragments and a rapakivi alkali feldspar rimmed by plagioclase (xenocryst from Mt. Veta intrusion?), and 1-mm-thick carbonate veinlets, also were observed in thin section.

\section{Results}

Zircons from core sample LWM 07-06-124 (quartz diorite) are pale tan to colorless, have length-to-width ratios $(1 / \mathrm{w})$ of about 2 to 5 , and contain few inclusions or cracks. CL imaging shows simple, oscillatory zoning (fig. $7)$ typical of an igneous origin. The grains are pristine and undamaged. $U$ contents of the zircons ( $\sim 70$ to $300 \mathrm{ppm}$ ) are relatively low. The weighted average age of 15 analyses is $210 \pm 3 \mathrm{Ma}$ (fig. 7), which is interpreted as the time of emplacement of the quartz diorite. Two additional analyses with ages of $267 \mathrm{Ma}$ (probably due to inheritance) and 184 $\mathrm{Ma}$ (probably due to minor $\mathrm{Pb}$ loss) were excluded from the age calculation.

Zircons from surface sample 07ADb01A (quartz monzonite) are medium tan, have $1 / \mathrm{w}$ of 1 to 3 , and generally are free of inclusions and cracks. CL imaging shows simple, concentric, oscillatory zoning, typical of an igneous origin (fig. 7). In most grains, the core areas are darker in CL (that is, higher in U) than the rims. All SHRIMP analyses are on the outer, lighter (in CL) portions of the grains, in order to avoid possible inherited components in the cores. The analyzed zones mostly contain about $150-$ $400 \mathrm{ppm}$ U. These grains do not resemble zircons extracted from quartz diorite sample LWM 07-06-124. The weighted average age of 17 analyses is $187 \pm 3 \mathrm{Ma}$, interpreted as the time of emplacement of the quartz monzonite. Two slightly younger ages of 169 and $176 \mathrm{Ma}$ (perhaps discordant due to minor $\mathrm{Pb}$ loss) were excluded from the age calculation.

Zircons from core sample FISH 06-04-35 (rhyolite) are medium to pale tan and have $1 / \mathrm{w}$ of 2 to 3 . Many of the grains contain cracks and inclusions; most are partially iron-stained. Imperfect grains were avoided during the hand-picking process, such that the analyzed grains were fairly pristine. Most of the zircon grains contain relatively light (in CL) cores and darker (that is, higher $\mathrm{U}$ ) rims (fig. 7). $U$ concentrations in the analyzed zones (mostly darker 
Table 2. Sensitive high-resolution ion microprobe (SHRIMP) U-Th-Pb data for zircon from the Fortymile dstrict, east-central Alaska.

[All samples analyzed on the U.S. Geological Survey/Stanford ion microprobe (SHRIMP-RG) in December, 2007. ppm, parts per million; Ma, mega-annum]

\begin{tabular}{|c|c|c|c|c|c|c|c|c|c|c|c|}
\hline $\begin{array}{l}\text { Sample } \\
\text { (location) }\end{array}$ & $\begin{array}{c}\text { Measured } \\
\frac{{ }^{204} \mathrm{~Pb}}{{ }^{206} \mathrm{~Pb}}\end{array}$ & $\begin{array}{c}\text { Measured } \\
\frac{{ }^{207} \mathrm{~Pb}}{{ }^{206} \mathrm{~Pb}}\end{array}$ & $\begin{array}{c}\% \\
\text { common } \\
{ }^{206} \mathrm{~Pb}\end{array}$ & $\begin{array}{c}\mathrm{U} \\
(\mathrm{ppm})\end{array}$ & $\mathrm{Th} / \mathrm{U}$ & $\frac{{ }^{206} \mathrm{~Pb}^{1}}{{ }^{238} \mathrm{U}}(\mathrm{Ma})$ & $\begin{array}{c}\mathrm{err}^{2} \\
(\mathrm{Ma})\end{array}$ & $\frac{{ }^{238} \mathrm{U}^{3}}{{ }^{206} \mathrm{~Pb}}$ & $\begin{array}{l}\mathrm{err}^{3} \\
(\%)\end{array}$ & $\frac{{ }^{207} \mathrm{~Pb}^{4}}{{ }^{206} \mathrm{~Pb}}$ & $\begin{array}{l}\mathrm{err}^{3} \\
(\%)\end{array}$ \\
\hline \multicolumn{12}{|c|}{ LWM 07-06-124 [64¹4’07”; 14249’37”; I.D. number 1, table 1, fig. 5] } \\
\hline LWM124-1.1 & 0.000808 & 0.0578 & 0.93 & 93 & 0.28 & 211.5 & 4.9 & 30.15 & 2.5 & .0459 & 18.4 \\
\hline LWM124-2.1 & 0.000303 & 0.0503 & -0.03 & 104 & 0.27 & 218.9 & 4.4 & 29.13 & 2.1 & .0458 & 8.6 \\
\hline LWM124-3.1 & --- & 0.0541 & 0.48 & 90 & 0.23 & 208.5 & 4.5 & 30.28 & 2.1 & .0541 & 5.6 \\
\hline LWM124-4.1 & --- & 0.0482 & -0.27 & 102 & 0.24 & 213.2 & 4.4 & 29.82 & 2.1 & .0482 & 5.6 \\
\hline LWM124-5.1 & --- & 0.0541 & 0.48 & 76 & 0.25 & 208.3 & 4.7 & 30.30 & 2.3 & .0541 & 6.0 \\
\hline LWM124-6.1 & 0.000541 & 0.0512 & 0.11 & 167 & 0.33 & 211.6 & 3.8 & 30.24 & 1.9 & .0432 & 9.8 \\
\hline LWM124-7.1 & -0.000108 & 0.0525 & 0.26 & 261 & 0.26 & 215.5 & 3.5 & 29.28 & 1.6 & .0541 & 3.5 \\
\hline LWM124-8.1 & 0.001604 & 0.0995 & 5.98 & 122 & 0.37 & 266.5 & 5.5 & 22.95 & 2.4 & .0768 & 14.4 \\
\hline LWM124-9.1 & 0.000394 & 0.0491 & -0.13 & 340 & 0.63 & 202.2 & 3.2 & 31.66 & 1.6 & .0433 & 7.9 \\
\hline LWM124-10.1 & 0.000223 & 0.0475 & -0.35 & 228 & 0.30 & 209.0 & 3.5 & 30.58 & 1.7 & .0442 & 6.1 \\
\hline LWM124-11.1 & 0.000710 & 0.0490 & -0.16 & 129 & 0.25 & 205.0 & 3.9 & 31.40 & 2.0 & .0384 & 14.0 \\
\hline LWM124-12.1 & 0.000595 & 0.0509 & 0.06 & 171 & 0.37 & 213.2 & 3.8 & 30.06 & 1.9 & .0420 & 10.7 \\
\hline LWM124-13.1 & --- & 0.0516 & 0.16 & 142 & 0.27 & 209.1 & 4.0 & 30.28 & 1.9 & .0516 & 4.7 \\
\hline LWM124-14.1 & 0.001287 & 0.0497 & -0.09 & 115 & 0.33 & 212.7 & 4.3 & 30.56 & 2.2 & .0303 & 26.2 \\
\hline LWM124-15.1 & 0.002963 & 0.0902 & 5.07 & 73 & 0.28 & 184.3 & 4.5 & 34.63 & 3.3 & .0465 & 42.6 \\
\hline LWM124-16.1 & --- & 0.0515 & 0.16 & 365 & 0.69 & 206.8 & 3.2 & 30.62 & 1.6 & .0515 & 2.8 \\
\hline LWM124-17.1 & 0.000059 & 0.0520 & 0.22 & 555 & 0.54 & 209.9 & 3.1 & 30.19 & 1.5 & .0512 & 2.5 \\
\hline \multicolumn{12}{|c|}{ 07ADb01A [64 $15.408^{\prime} ; 142^{\circ} 42.001$; I.D. number 2 , table 1 , fig. 5] } \\
\hline ADB01A-1.1 & 0.000072 & 0.0503 & 0.06 & 748 & 0.68 & 183.0 & 2.7 & 34.76 & 1.5 & .0492 & 2.8 \\
\hline ADB01A-2.1 & --- & 0.0495 & -0.06 & 228 & 0.32 & 192.0 & 3.3 & 33.09 & 1.7 & .0495 & 3.8 \\
\hline ADB01A-3.1 & 0.000311 & 0.0541 & 0.55 & 177 & 0.37 & 181.7 & 3.3 & 34.98 & 1.8 & .0495 & 7.6 \\
\hline ADB01A-4.1 & 0.000291 & 0.0524 & 0.32 & 186 & 0.36 & 188.2 & 3.3 & 33.84 & 1.8 & .0481 & 6.3 \\
\hline ADB01A-5.1 & --- & 0.0493 & -0.02 & 193 & 0.36 & 168.8 & 3.1 & 37.70 & 1.8 & .0493 & 5.0 \\
\hline ADB01A-6.1 & 0.000296 & 0.0516 & 0.22 & 170 & 0.40 & 185.3 & 3.4 & 34.41 & 1.9 & .0472 & 8.3 \\
\hline ADB01A-7.1 & --- & 0.0488 & -0.14 & 278 & 0.44 & 193.9 & 3.2 & 32.79 & 1.6 & .0488 & 3.4 \\
\hline ADB01A-8.1 & 0.000161 & 0.0467 & -0.40 & 273 & 0.42 & 191.0 & 3.1 & 33.48 & 1.6 & .0444 & 5.3 \\
\hline ADB01A-9.1 & 0.000340 & 0.0512 & 0.18 & 241 & 0.44 & 182.0 & 3.2 & 35.08 & 1.8 & .0462 & 12.7 \\
\hline ADB01A-10.1 & --- & 0.0514 & 0.21 & 421 & 0.49 & 180.3 & 2.8 & 35.17 & 1.5 & .0514 & 2.7 \\
\hline ADB01A-11.1 & 0.000468 & 0.0511 & 0.16 & 155 & 0.32 & 186.3 & 3.4 & 34.34 & 1.9 & .0441 & 12.8 \\
\hline ADB01A-12.1 & -0.000406 & 0.0465 & -0.43 & 237 & 0.36 & 191.8 & 3.2 & 33.00 & 1.7 & .0524 & 6.5 \\
\hline ADB01A-13.1 & --- & 0.0508 & 0.15 & 156 & 0.35 & 177.5 & 3.4 & 35.76 & 1.9 & .0508 & 4.8 \\
\hline ADB01A-14.1 & --- & 0.0496 & -0.03 & 360 & 0.38 & 186.9 & 3.0 & 34.01 & 1.6 & .0496 & 3.1 \\
\hline ADB01A-15.1 & 0.000331 & 0.0493 & -0.06 & 154 & 0.37 & 184.6 & 3.4 & 34.65 & 1.9 & .0444 & 7.6 \\
\hline ADB01A-16.1 & -0.000251 & 0.0493 & -0.06 & 205 & 0.33 & 185.7 & 3.3 & 34.07 & 1.8 & .0530 & 5.1 \\
\hline ADB01A-17.1 & --- & 0.0477 & -0.27 & 245 & 0.46 & 190.4 & 3.2 & 33.46 & 1.7 & .0477 & 3.6 \\
\hline ADB01A-18.1 & 0.000095 & 0.0500 & 0.00 & 373 & 0.29 & 191.4 & 3.0 & 33.24 & 1.6 & .0486 & 3.6 \\
\hline ADB01A-19.1 & 0.000110 & 0.0491 & -0.11 & 310 & 0.28 & 193.0 & 3.1 & 33.00 & 1.6 & .0474 & 3.9 \\
\hline \multicolumn{12}{|c|}{ FISH 06-04-35 [64¹5'39”; 14242’17’; I.D. number 3, table 1, fig. 5] } \\
\hline FISH-35-1-1.1 & 0.000313 & 0.0482 & 0.11 & 227 & 0.71 & 66.4 & 1.4 & 96.99 & 2.0 & .0436 & 9.4 \\
\hline FISH-35-1-2.1 & 0.000236 & 0.0500 & 0.32 & 300 & 0.54 & 69.6 & 1.3 & 92.19 & 1.8 & .0465 & 6.9 \\
\hline FISH-35-1-3.1 & 0.000361 & 0.0483 & 0.11 & 208 & 0.70 & 69.9 & 1.4 & 92.22 & 2.1 & .0429 & 10.4 \\
\hline FISH-35-1-4.1 & 0.000088 & 0.0463 & -0.13 & 1321 & 0.38 & 69.8 & 1.0 & 92.18 & 1.5 & .0451 & 2.9 \\
\hline FISH-35-1-5.1 & -0.000623 & 0.0506 & 0.40 & 478 & 0.87 & 71.4 & 1.2 & 88.41 & 1.8 & .0596 & 8.2 \\
\hline FISH-35-1-6.1 & --- & 0.0474 & 0.00 & 1377 & 0.34 & 70.0 & 1.0 & 91.59 & 1.4 & .0474 & 2.3 \\
\hline FISH-35-1-7.1 & 0.000140 & 0.0456 & -0.22 & 1634 & 0.33 & 68.5 & 1.0 & 94.09 & 1.4 & .0436 & 3.3 \\
\hline FISH-35-1-8.1 & 0.000085 & 0.0461 & -0.17 & 1250 & 0.43 & 71.1 & 1.0 & 90.43 & 1.5 & .0448 & 2.9 \\
\hline FISH-35-1-9.1 & --- & 0.0476 & -0.07 & 563 & 0.07 & 107.9 & 1.7 & 59.28 & 1.6 & .0476 & 2.8 \\
\hline FISH-35-1-10.1 & --- & 0.0441 & -0.45 & 163 & 0.25 & 83.4 & 1.8 & 77.10 & 2.1 & .0441 & 6.5 \\
\hline FISH-35-1-11.1 & 0.000148 & 0.0509 & 0.45 & 478 & 0.38 & 66.8 & 1.1 & 95.81 & 1.7 & .0487 & 4.9 \\
\hline FISH-35-1-12.1 & 0.000071 & 0.0470 & -0.06 & 1209 & 0.43 & 73.0 & 1.1 & 88.02 & 1.5 & .0460 & 5.1 \\
\hline FISH-35-1-13.1 & -0.000472 & 0.0468 & -0.08 & 740 & 0.71 & 72.6 & 1.2 & 87.61 & 1.6 & .0537 & 7.0 \\
\hline FISH-35-1-14.1 & --- & 0.0462 & -0.15 & 1054 & 0.26 & 68.4 & 1.0 & 93.90 & 1.5 & .0462 & 3.1 \\
\hline FISH-35-1-15.1 & 0.000173 & 0.0476 & 0.02 & 1524 & 0.44 & 69.5 & 1.0 & 92.51 & 1.5 & .0450 & 3.6 \\
\hline FISH-35-1-16.1 & 0.000166 & 0.0476 & 0.02 & 984 & 0.27 & 71.9 & 1.1 & 89.44 & 1.6 & .0452 & 4.9 \\
\hline FISH-35-1-17.1 & --- & 0.0464 & -0.13 & 1307 & 0.39 & 72.0 & 1.1 & 89.20 & 1.5 & .0464 & 2.7 \\
\hline
\end{tabular}

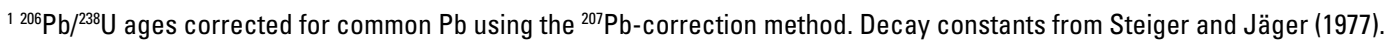

2 1-sigma errors.

${ }^{3}$ radiogenic ratios, corrected for common $\mathrm{Pb}$ using the ${ }^{204} \mathrm{~Pb}$-correction method, based on the Stacey and Kramers (1975) model. 
$A$
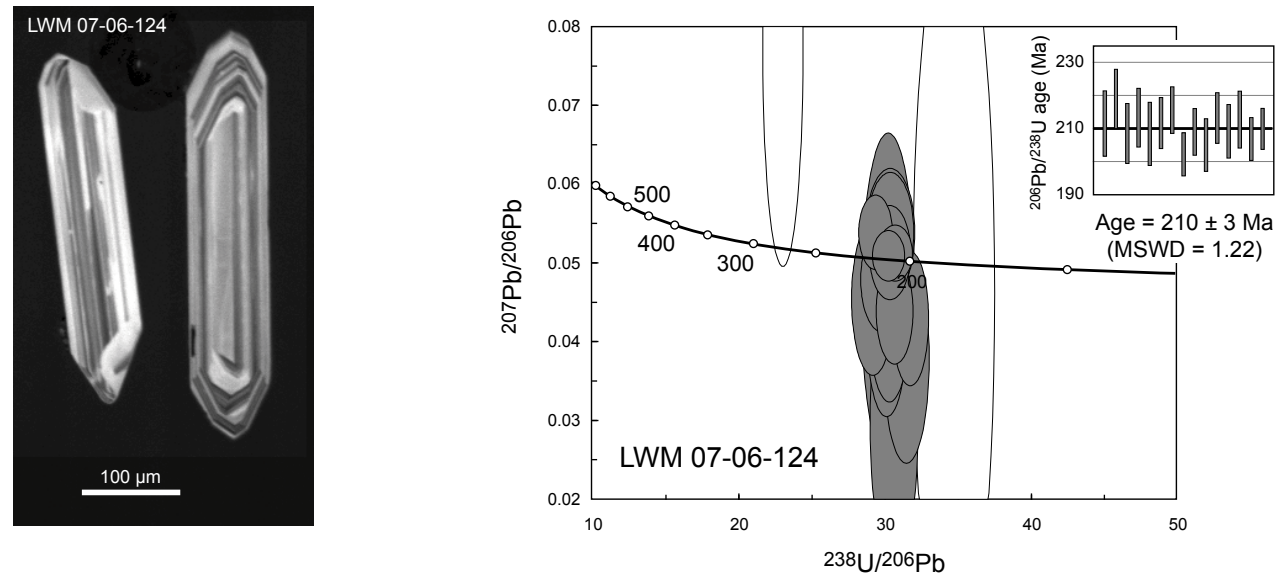

$\boldsymbol{B}$
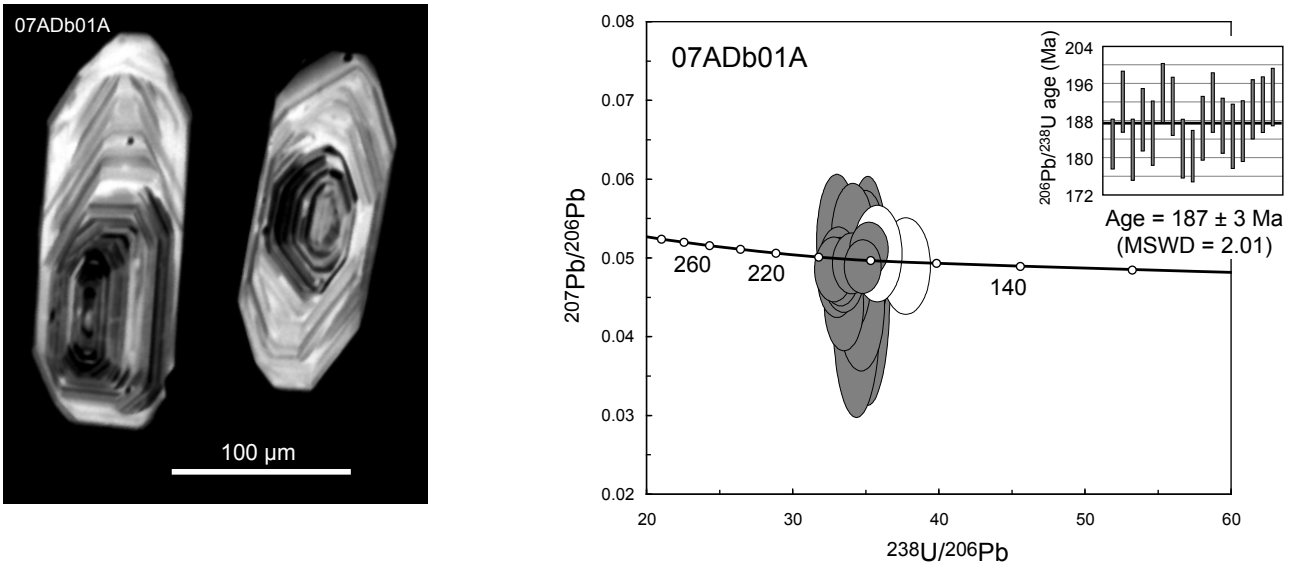

C
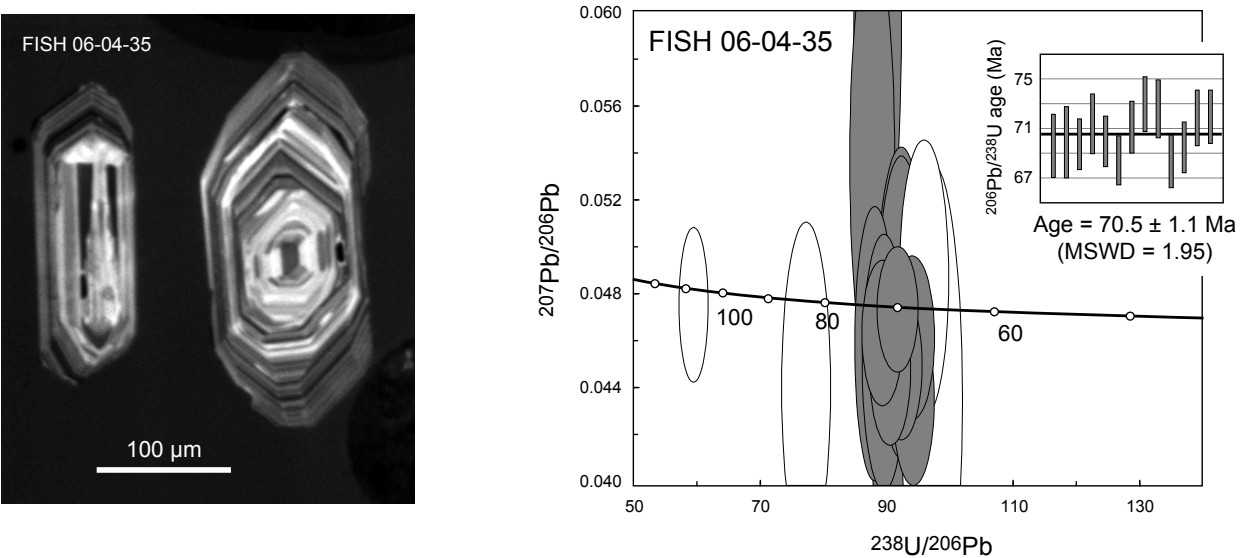

Figure 7. Representative cathodoluminescence $(\mathrm{CL})$ images and concordia plots of $\mathrm{U}-\mathrm{Pb}$ data obtained by SHRIMP-RG analysis of zircons in samples from the Mount Veta area. $A$, LWM 07-06-124; $B, 07 \mathrm{ADb} 01 \mathrm{~A}$; and $C$, Fish 06-04-35. See text for explanation. MSWD, mean square of weighted deviates. 
in CL) range from about 160 to $1,630 \mathrm{ppm}$. Most SHRIMP analyses are on the outer portions of the grains to avoid possible complications due to inheritance. The weightedaverage age of 13 analyses is $70.5 \pm 1.1 \mathrm{Ma}$, interpreted as the time of crystallization of the rhyolite. Two slightly younger ages (66 and $67 \mathrm{Ma}$, perhaps due to minor $\mathrm{Pb}$ loss) and two older ages (108 and 83 Ma, probably due to inheritance of xenocrystic material; table 2) were excluded from the age calculation.

\section{Igneous Whole-Rock Geochemistry}

Whole-rock geochemical analyses for the dated Mesozoic igneous rocks are given in table 3 . All samples, except those collected in 1991, were analyzed by wavelength-dispersive X-ray fluorescence (XRF) and inductively coupledplasma mass spectrometry (ICP-MS) at the GeoAnalytical Laboratory, Washington State University (Knaack and others, 1994; Johnson and others, 1999). The three 1991 samples were analyzed at the USGS under the following conditions: (1) samples were ground in an alumina shatterbox; (2) major elements were determined by wavelengthdispersive XRF on fused glass disks; (3) $\mathrm{Ba}, \mathrm{Rb}, \mathrm{Sr}, \mathrm{Y}$, and $\mathrm{Zr}$ were determined by energy-dispersive XRF; (4) emission spectroscopy was used for determination of $\mathrm{Cu}, \mathrm{Ni}$, and $\mathrm{V}$; (5) niobium was analyzed by inductively coupledplasma atomic emision spectrometry (ICP-AES) following quantitative chemical separation; (6) the remaining elements were analyzed by instrumental neutron-activation analysis. Analytical precision and accuracy for the USGS analytical techniques are reported in Dusel-Bacon and Cooper (1999).

Petrographic differentiation of potassium-feldspar and plagioclase is difficult in some samples because of alteration and lack of stained slabs. However, our petrographic observations are consistent with the rock names determined by the IUGS plutonic-rock classification of Streckeisen (1976; fig. 8A), based on volume percent quartz $(\mathrm{Q})$, orthoclase (Or), and albite (Ab) + anorthite (An), calculated using the weight-percent normalization scheme of Streckeisen and LeMaitre (1979) and the normative Ab-An-Or plot of Barker (1979; fig. 8B). The diagrams in figure 8 depict the extreme loss of $\mathrm{Na}$ during alteration of the Late Cretaceous rhyolite porphyry in the Fish drill core. These diagrams also show a compositional evolution of the Mesozoic plutons with time, from more dioritic or tonalitic in the Late Triassic, to more granodioritic near the Late Triassic-Early Jurassic boundary, to more granitic in the Early Jurassic. The compositional fields shown in figures $8 \mathrm{~A}$ and $8 \mathrm{C}$ fall mostly within the overlapping fields of island arc granitoids and continental arc granitoids accord- ing to the tectonic-discrimination scheme proposed by Maniar and Piccoli (1989). Despite the likelihood of some major-element mobility, all of the analyzed samples follow a calc-alkalic compositional trend shown by decreasing $\mathrm{FeO}^{*} / \mathrm{MgO}$ with decreasing $\mathrm{TiO}_{2}$ (fig. $8 \mathrm{C}$ ). A plot of $\mathrm{Al} /(\mathrm{Na}$ $+\mathrm{K})$ versus $\mathrm{Al} /(\mathrm{Ca}+\mathrm{Na}+\mathrm{K})$ classifies most samples as metaluminous or weakly peraluminous (fig. $8 D$ ).

Following the approach of previous geochemical studies in the region (Dusel-Bacon and others, 2004, 2006), we use trace-element geochemistry here in order to understand the tectonic setting and petrogenesis of the metaigneous rocks. The elements employed in this tectonic fingerprinting are those that are relatively immobile up to middle amphibolite-facies metamorphism and during hydrothermal alteration at low water:rock ratios (for example, Pearce, 1982; Pearce and others, 1984). These immoble elements include the high-field-strength elements (HFSE) Zr, Hf, $\mathrm{Nb}$, Ta, and Ti; rare-earth elements (REE) La through $\mathrm{Lu}$ (except $\mathrm{Eu}$ ); $\mathrm{Y}$ and $\mathrm{Ga}$; and, to a lesser degree, Th and $\mathrm{Al}$. In the $\mathrm{Ta}$ versus $\mathrm{Yb}$ tectonic-discrimination diagram (fig. $8 E$ ), all of the igneous samples plot in the volcanic-arc granite field.

Figure 9 shows primitive mantle-normalized multielement patterns of representative magma types (fig. $9 A$ ) for comparison with those of the igneous rocks from the Fortymile region (fig. $9 B-F$; table 3 ). In general, at a given $\mathrm{SiO}_{2}$ concentration or other fractionation index, felsic rocks that formed in within-plate (extensional) settings have higher total REE and HFSE contents and lower compatible-element concentrations (Ti) relative to arc rocks and to average upper and lower continental crust. Withinplate igneous rocks are represented by Pleistocene rhyolite from the Yellowstone Plateau volcanic field (Hildreth and others, 1991), an unambiguous intracontinental setting. Because the chemistry of continental-margin arc magmas is variable and depends on local crustal composition and thickness (Hildreth and Moorbath, 1988), we include plots of a continental-margin arc emplaced on both a thick (70 to $80 \mathrm{~km}$ ) crust in the central Andes of Chile (Lindsay and others, 2001) and on a thinner ( $40 \mathrm{~km})$ crust composed of accreted terranes at Mount Mazama, Crater Lake, Oregon (Bacon and Druitt, 1988).

All of the Fortymile igneous samples display deep troughs in $\mathrm{Nb}$ and Ta relative to adjacent elements (figs. $9 B-F$ ) that are characteristic of arc magmas (for example, Sun and McDonough, 1989). The trace-element patterns of the various age groupings also show an increase in the crustal contribution to the melt through time, indicated by increasing concentrations of Th and adjacent incompatible elements, on the left side of each diagram. The flatter, multielement pattern and overall lower trace-element contents of the Late Triassic samples are consistent with their more 
L. Cretaceous (70 Ma)—Fish rhyolite

Granitoid samples (age in Ma)

+ E.Cretaceous (105-107)

$\triangle$ E. Jurassic (185-193)

E. Jurassic (187) 07ADb01

E. Jurassic - L.Triassic (197-201)

L.Triassic (212-215)

L.Triassic (210) LWM
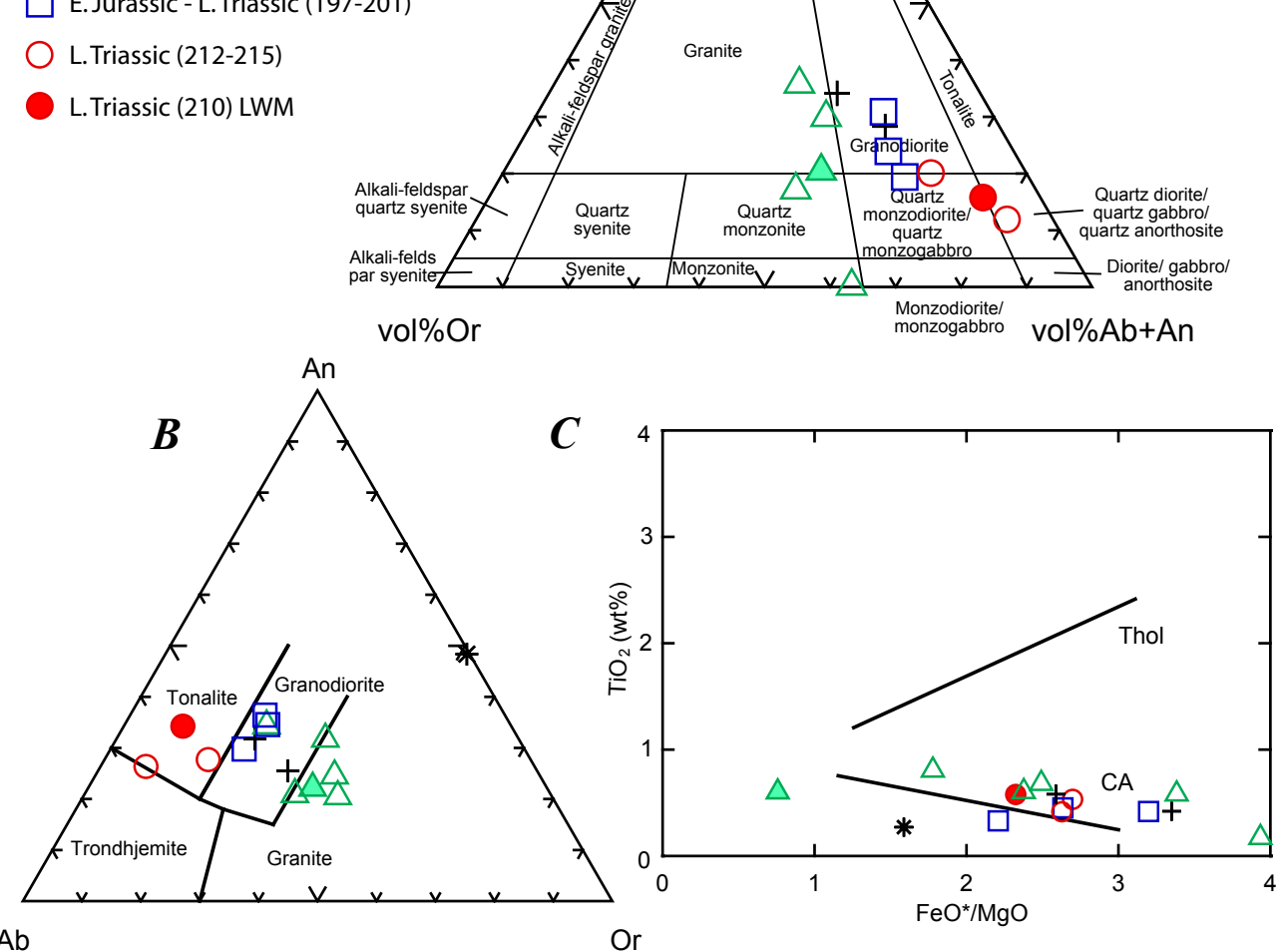

$\mathrm{Ab}$

Or
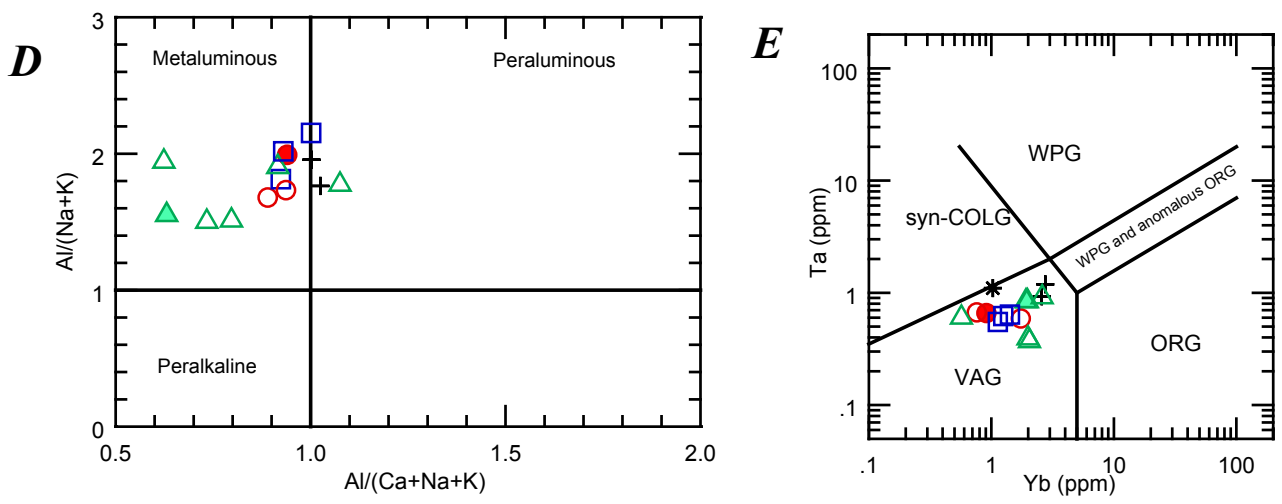

Figure 8. Selected discrimination diagrams showing geochemical data for Mesozoic igneous rocks from the Fortymile district. $A$, IUGS plutonic-rock classification (Streckeisen, 1976) based on volumepercent orthoclase (Or), quartz ( 0 ), and albite $(A b)+$ anorthite $(A n)$. B, Normative plot of $A b-A n-0 r$ showing fields for siliceous plutonic rocks (Barker, 1979). C, Variation trend of $\mathrm{TiO}_{2}$ with increasing $\mathrm{FeO}$ * (all iron calculated as $\mathrm{Fe} 0$ ) / $\mathrm{MgO}$. Thol, example of a tholeiitic compositional trend; $\mathrm{CA}$, example of a calc-alkaline compositional trend (Miyashiro, 1974). D, Shand's index classification (Maniar and Piccoli, 1989). $E$, Ta versus $\mathrm{Yb}$ tectonic discrimination diagram (Pearce and others, 1984). WPG, within-plate granite; syn-COLG, syncollisional granite; $V A G$, volcanic-arc granite; $\mathrm{ORG}$, ocean ridge-type granite. 

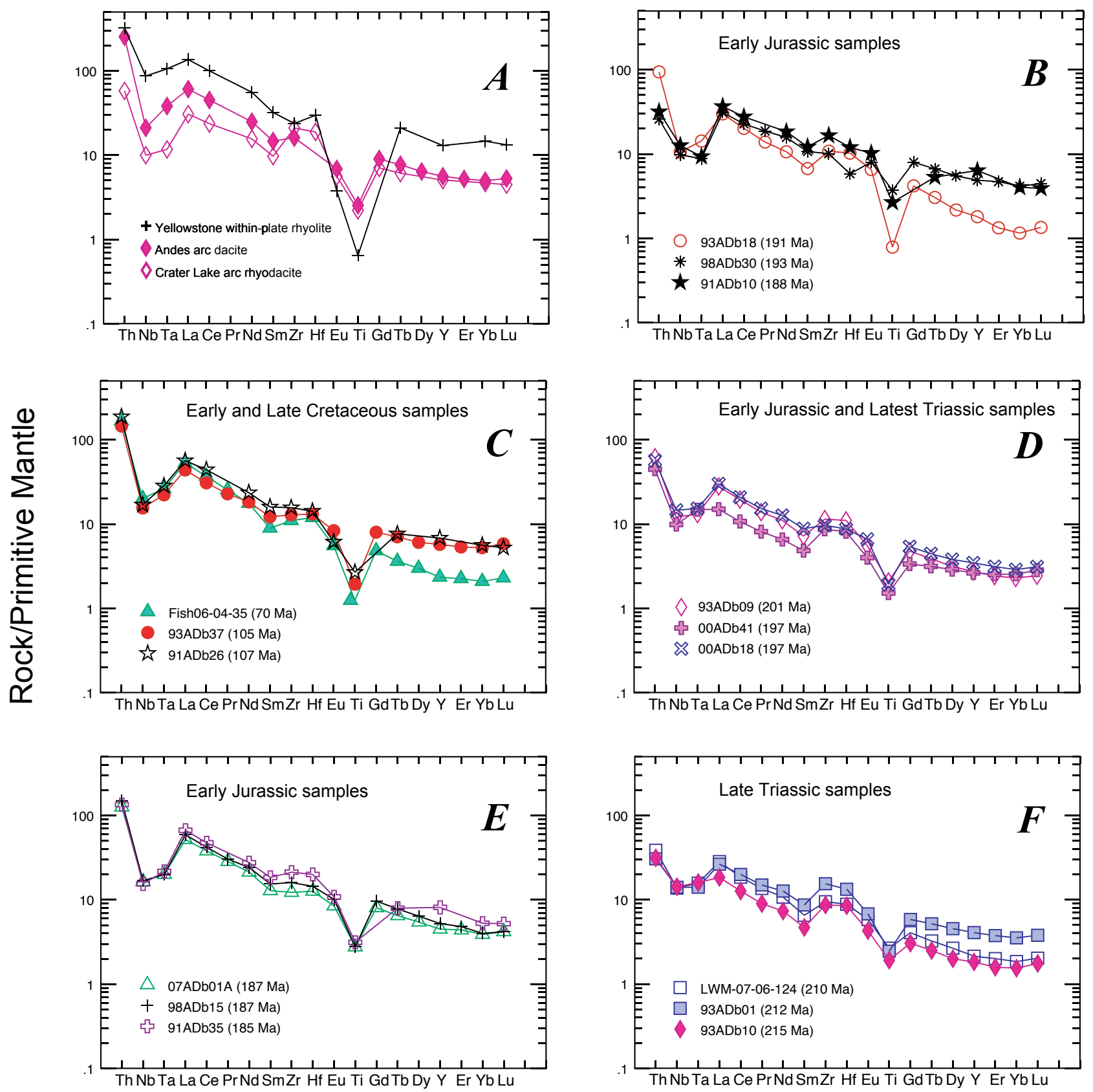

Figure 9. Primitive mantle-normalized plots of trace-element data for Fortymile Mesozoic igneous rocks. $A$, Average or representative trace-element compositions of characteristic magma types. Data sources for felsic analyses of magmatic rocks from known environments: Yellowstone within-plate rhyolite = average of three intracaldera flows $\left(76.9\right.$ percent $\left.\mathrm{SiO}_{2}\right)$ from the Yellowstone Plateau volcanic field representing one of the world's largest silicic volcanic centers, associated with lesser volumes of basalt in a within-plate continental setting (Hildreth and others, 1991); Andes arc dacite = continental-margin arc, central Andes, Chile, average of two Atana dacite pumice samples (Lari-96h-6 x-rich and Quis-96h-9 x-rich; 67.1 percent $\mathrm{SiO}_{2}$ ) from a large Pliocene ignimbrite erupted through 70-80 km-thick crust (Lindsay and others, 2001); Crater Lake arc rhyodacite = continental-margin arc, Crater Lake, Oregon, sample "Avg 3 CIP" from Bacon and Druitt (1988), representing average of pumice (70.4 percent $\mathrm{SiO}_{2}$ ) from Holocene climactic eruption of Mount Mazama on $40 \mathrm{~km}$-thick crust of Tertiary-Paleozoic accreted terranes. $B-F$, Plots of data for Fortymile samples; chemical analyses are reported in table 3; mapped figure locations and sample descriptions are given in table 1. Primitive mantle values from Sun and McDonough (1989). 
Table 3. Whole-rock geochemical analyses of dated Mesozoic rocks from the Fortymile district, east-central Alaska.

[LOI, loss on ignition; ppm, parts per million. All samples, except those collected in 1991, were analyzed by wavelength-dispersive X-ray flourescence (XRF) and inductively coupled-plasma mass spectrometry (ICP-MS). Methods used for chemical analysis of all samples are explained or referenced in the text. XRFwt\% is weight percent normalized to 100 percent. Abbreviations explained in table 1]

\begin{tabular}{|c|c|c|c|c|c|c|c|c|c|c|c|c|c|c|c|}
\hline I.D. number (figure) & 1 (fig. 5 ) & 2 (fig. 5) & 3 (fig. 5) & 4 (fig. 5) & 5 (fig. 4) & 6 (Fig.4) & 7 (Fig. 4) & 8 (fig. 3 ) & 9 (fig. 3) & 10 (fig.3) & 11 (fig. 3) & 12 (fig. 3) & 13 (fig.3) & 14 (fig.3) & 15 (fig. 2) \\
\hline Sample & LWM-07-06-124 & $07 \mathrm{ADb} 01 \mathrm{~A}$ & Fish06-04-35 & 91ADb35 & $91 \mathrm{ADb} 26$ & 93ADb09 & 93ADb10 & 93ADb18 & $98 \mathrm{ADb} 30$ & 00ADb41 & $00 \mathrm{ADb} 18$ & 98ADb15 & $91 \mathrm{ADb} 10$ & 93ADb37 & 93ADb01 \\
\hline Geologic unit & $\operatorname{Trg}$ & $\mathrm{Jg}$ & Krhy & $\mathrm{Jg}$ & $\mathrm{Kg}$ & $\operatorname{Trg}$ & $\operatorname{Trg}$ & $\mathrm{Jg}$ & $\mathrm{Jg}$ & $\mathrm{Jg}$ & $\mathrm{Jg}$ & $\mathrm{Jg}$ & $\mathrm{Jg}$ & $\mathrm{Kg}$ & $\operatorname{Trg}$ \\
\hline Quadrangle & EAA-4 & EA B-4 & EA B-4 & EAA-5 & EAA-6 & EA A-4 & EAA-4 & EAA-3 & EAB-2 & EAB-1 & EA B-1 & EAA-1 & EAA-2 & EAA-2 & TA D-3 \\
\hline \multicolumn{16}{|l|}{ XRF wt $\%$} \\
\hline $\mathrm{SiO} 2$ & 62.29 & 63.92 & 75.88 & 61.96 & 69.34 & 64.34 & 65.71 & 72.20 & 52.08 & 67.80 & 64.97 & 66.69 & 57.05 & 67.22 & 62.47 \\
\hline $\mathrm{Al} 2 \mathrm{O} 3$ & 18.89 & 14.03 & 14.35 & 14.60 & 14.56 & 17.42 & 17.65 & 15.42 & 16.58 & 16.41 & 17.04 & 14.97 & 18.03 & 16.60 & 18.49 \\
\hline $\mathrm{TiO} 2$ & 0.578 & 0.599 & 0.270 & 0.68 & 0.58 & 0.452 & 0.416 & 0.171 & 0.804 & 0.33 & 0.418 & 0.603 & 0.58 & 0.42 & 0.532 \\
\hline $\mathrm{FeO}^{*}$ & 4.09 & 2.97 & 1.70 & 6.28 & 4.22 & 4.11 & 3.10 & 1.81 & 8.86 & 3.38 & 4.35 & 4.66 & 6.70 & 3.82 & 4.21 \\
\hline $\mathrm{MnO}$ & 0.101 & 0.096 & 0.049 & 0.14 & 0.09 & 0.085 & 0.078 & 0.043 & 0.191 & 0.11 & 0.103 & 0.108 & 0.15 & 0.12 & 0.105 \\
\hline $\mathrm{CaO}$ & 5.84 & 7.25 & 3.54 & 5.59 & 3.27 & 5.09 & 4.76 & 3.10 & 9.92 & 4.82 & 5.43 & 4.66 & 5.87 & 4.44 & 5.37 \\
\hline $\mathrm{MgO}$ & 1.76 & 3.92 & 1.07 & 2.52 & 1.63 & 1.56 & 1.18 & 0.46 & 4.98 & 1.53 & 1.36 & 1.96 & 1.98 & 1.14 & 1.56 \\
\hline $\mathrm{K} 2 \mathrm{O}$ & 1.27 & 3.97 & 3.05 & 4.75 & 3.19 & 2.75 & 2.19 & 4.21 & 2.62 & 2.44 & 2.79 & 3.67 & 4.82 & 2.60 & 1.01 \\
\hline $\mathrm{Na} 2 \mathrm{O}$ & 4.93 & 2.89 & 0.02 & 2.79 & 2.92 & 4.03 & 4.75 & 2.52 & 3.47 & 3.03 & 3.30 & 2.37 & 4.09 & 3.45 & 6.03 \\
\hline P2O5 & 0.247 & 0.352 & 0.080 & 0.68 & 0.20 & 0.159 & 0.165 & 0.058 & 0.491 & 0.15 & 0.240 & 0.320 & 0.73 & 0.20 & 0.227 \\
\hline \multicolumn{16}{|l|}{ XRF ppm } \\
\hline $\mathrm{Ni}$ & 0 & 17 & 0 & & & 3 & 0 & 4 & 22 & 1 & 3 & 5 & & 2 & 6 \\
\hline $\mathrm{Cr}$ & 7 & 99 & 7 & 28.9 & 6.3 & 6 & 4 & 5 & 64 & 7 & 2 & 20 & 9.8 & 0 & 11 \\
\hline $\mathrm{V}$ & 79 & 133 & 22 & & & 83 & 63 & 17 & 209 & 73 & 79 & 119 & & 49 & 82 \\
\hline $\mathrm{Zr}$ & 106 & 137 & 123 & 238 & 175 & 128 & 97 & 121 & 113 & 97 & 108 & 179 & 186 & 144 & 173 \\
\hline $\mathrm{Ga}$ & 20 & 15 & 16 & & & 18 & 17 & 17 & 20 & 16 & 19 & 19 & & 17 & 23 \\
\hline $\mathrm{Cu}$ & 2 & 6 & 1 & & & 5 & 8 & 6 & 3 & 0 & 11 & 0 & & 8 & 12 \\
\hline $\mathrm{Zn}$ & 60 & 58 & 39 & 74 & 57.4 & 53 & 45 & 42 & 99 & 42 & 44 & 73 & 75 & 67 & 59 \\
\hline \multicolumn{16}{|l|}{ ICP-MS ppm } \\
\hline $\mathrm{La}$ & 19.44 & 35.56 & 36.39 & 45.8 & 38.7 & 19.13 & 12.59 & 20.53 & 21.42 & 10.30 & 20.60 & 40.50 & 25.2 & 30.06 & 18.14 \\
\hline $\mathrm{Ce}$ & 32.86 & 67.58 & 65.27 & 84.3 & 78.4 & 34.70 & 22.52 & 35.92 & 40.50 & 19.06 & 36.96 & 74.58 & 49.2 & 54.83 & 35.43 \\
\hline $\operatorname{Pr}$ & 3.75 & 7.86 & 7.01 & & & 3.81 & 2.48 & 3.83 & 5.17 & 2.24 & 4.21 & 8.38 & & 6.28 & 4.12 \\
\hline $\mathrm{Nd}$ & 14.47 & 28.73 & 23.71 & 37.2 & 31.7 & 14.91 & 9.90 & 14.36 & 21.24 & 8.84 & 17.04 & 32.52 & 24.9 & 24.64 & 17.10 \\
\hline $\mathrm{Sm}$ & 2.90 & 5.69 & 3.96 & 8.18 & 7.07 & 3.19 & 2.08 & 2.99 & 4.75 & 2.15 & 3.91 & 6.84 & 5.41 & 5.40 & 3.85 \\
\hline $\mathrm{Eu}$ & 0.98 & 1.42 & 0.93 & 1.82 & 1.03 & 0.93 & 0.72 & 1.10 & 1.35 & 0.67 & 1.11 & 1.70 & 1.72 & 1.40 & 1.14 \\
\hline $\mathrm{Gd}$ & 2.42 & 4.80 & 2.87 & $\mathrm{n} / \mathrm{a}$ & $\mathrm{n} / \mathrm{a}$ & 2.85 & 1.82 & 2.50 & 4.76 & 2.00 & 3.21 & 5.76 & $\mathrm{n} / \mathrm{a}$ & 4.76 & 3.47 \\
\hline $\mathrm{Tb}$ & 0.35 & 0.70 & 0.39 & 0.860 & 0.827 & 0.42 & 0.27 & 0.33 & 0.72 & 0.34 & 0.48 & 0.84 & 0.575 & 0.76 & 0.56 \\
\hline Dy & 1.96 & 4.01 & 2.20 & & & 2.31 & 1.47 & 1.60 & 4.06 & 2.12 & 2.80 & 4.71 & & 4.47 & 3.34 \\
\hline Ho & 0.37 & 0.79 & 0.41 & 2.0 & 1.18 & 0.45 & 0.29 & 0.28 & 0.82 & 0.42 & 0.55 & 0.90 & 2.0 & 0.93 & 0.67 \\
\hline Er & 0.96 & 2.11 & 1.08 & & & 1.16 & 0.76 & 0.64 & 2.26 & 1.22 & 1.50 & 2.31 & & 2.56 & 1.80 \\
\hline $\mathrm{Tm}$ & 0.14 & 0.31 & 0.16 & $\mathrm{n} / \mathrm{a}$ & $\mathrm{n} / \mathrm{a}$ & 0.17 & 0.12 & 0.09 & 0.34 & 0.19 & 0.22 & 0.33 & $\mathrm{n} / \mathrm{a}$ & 0.40 & 0.27 \\
\hline $\mathrm{Yb}$ & 0.91 & 1.92 & 1.03 & 2.60 & 2.76 & 1.13 & 0.76 & 0.57 & 2.05 & 1.25 & 1.42 & 1.97 & 1.99 & 2.58 & 1.74 \\
\hline $\mathrm{Lu}$ & 0.15 & 0.31 & 0.17 & 0.386 & 0.386 & 0.18 & 0.13 & 0.10 & 0.33 & 0.21 & 0.23 & 0.31 & 0.290 & 0.43 & 0.28 \\
\hline $\mathrm{Ba}$ & 715 & 1581 & 319 & 1574 & 775 & 1208 & 844 & 1791 & 2199 & 1785 & 1730 & 2043 & 2564 & 1771 & 824 \\
\hline Th & 3.27 & 10.69 & 14.12 & 11.4 & 15.9 & 5.25 & 2.66 & 7.99 & 2.20 & 3.80 & 4.82 & 12.70 & 2.7 & 12.29 & 2.59 \\
\hline $\mathrm{Nb}$ & 9.78 & 11.73 & 14.30 & 11 & 12 & 8.62 & 10.14 & 7.54 & 7.00 & 7.02 & 10.40 & 12.01 & 9 & 11.06 & 10.00 \\
\hline Y & 9.73 & 20.42 & 10.65 & 37 & 31 & 12.44 & 8.30 & 8.23 & 22.25 & 11.98 & 15.75 & 23.75 & 29 & 26.07 & 18.52 \\
\hline $\mathrm{Hf}$ & 2.73 & 3.90 & 3.68 & 6.17 & 4.39 & 3.41 & 2.62 & 3.17 & 1.80 & 2.50 & 2.70 & 4.46 & 3.7 & 4.05 & 4.11 \\
\hline Тa & 0.66 & 0.84 & 1.10 & 0.910 & 1.190 & 0.55 & 0.67 & 0.60 & 0.37 & 0.62 & 0.64 & 0.84 & 0.392 & 0.93 & 0.59 \\
\hline $\mathrm{U}$ & 1.29 & 3.64 & 2.64 & 1.77 & 3.21 & 1.10 & 0.77 & 1.93 & 0.69 & 2.14 & 2.70 & 2.28 & 1.30 & 3.43 & 0.88 \\
\hline $\mathrm{Pb}$ & 5.73 & 39.22 & 21.45 & & & 9.84 & 6.51 & 23.64 & 5.83 & 13.49 & 8.02 & 13.91 & & 28.64 & 5.62 \\
\hline $\mathrm{Rb}$ & 23.0 & 86.3 & 120.6 & 111 & 116 & 80.6 & 53.1 & 104.3 & 34.8 & 73.7 & 69.6 & 92.4 & 99 & 93.2 & 20.6 \\
\hline $\mathrm{Cs}$ & 4.66 & 1.56 & 10.91 & 0.25 & 3.85 & 1.88 & 0.75 & 1.82 & 0.33 & 3.79 & 1.65 & 2.22 & 0.67 & 2.57 & 0.54 \\
\hline $\mathrm{Sr}$ & 1092 & 686 & 94 & 996 & 237 & 820 & 745 & 630 & 1071 & 850 & 1305 & 715 & 1331 & 514 & 1197 \\
\hline Sc & 6.2 & 15.9 & 3.5 & 16.5 & 11.33 & 8.6 & 6.7 & 4.4 & 21.6 & 9.2 & 8.7 & 15.2 & 10.09 & 7.9 & 8.0 \\
\hline
\end{tabular}


tonalitic and dioritic compositions. The Early and Late Cretaceous samples are the most crustally contaminated, having multielement patterns that are similar to those of a continental-margin arc emplaced on thick crust (figs. $9 \mathrm{~A}$ and $C$ )

\section{Base-Metal Mineralization in the Fortymile District}

Numerous epigenetic base- and precious-metal occurrences have been identified and explored to varying degrees within the Fortymile district of the southern Eagle quadrangle (Werdon and others, 2004, and references therein). In 2006 and 2007, Full Metal Minerals, USA, Inc., conducted extensive surface exploration, including ground-based magnetometer surveys and soil grid sampling, and diamond drilling at Fish and Little Whiteman (LWM) prospects in the Mount Veta area in the western part of the district (figs. 4 and 5). The two drilled prospects, named after local creeks, contain multiple zones of high-grade $\mathrm{Zn}, \mathrm{Pb}$, and $\mathrm{Ag} ; \mathrm{Cu}$ contents are locally high at Fish. These discoveries, together with surface showings of similar mineralized rock, such as at the Eva Creek and Drumstick prospects (fig. 4), are interpreted by Full Metal Minerals geologists as hightemperature, carbonate-replacement deposits (CRD) that occur within a 90-km-long, northeast-trending belt in the Fortymile district (McLeod, 2008; Light and others, 2008). Associated with these proposed CRD are numerous marblehosted, base-metal skarn prospects, including Oscar, Mitchell, and West Little Whiteman. The base-metal occurrences in the Mount Veta area, described below, constitute the southwestern end of the belt.

The northeastern end of the belt is defined by the Lead Creek and Champion Creek prospects (fig. 3; Dusel-Bacon and others, 2003; Werdon and others, 2004). Diamond drilling at the Lead Creek $\mathrm{Pb}-\mathrm{Zn}-\mathrm{Ag}$ prospect showed three thrust sheets - (1) an upper sheet composed of graphitic and micaceous schist (Nasina assemblage); (2) a middle sheet of greenstone, siltstone, and limestone (Seventymile terrane); and (3) a lower sheet of predominantly Triassic limestone and low-grade sedimentary rocks (Seventymile terrane; WGM, Inc., 2001; Dusel-Bacon and others, 2003). Fine-grained, felsic, porphyritic igneous rock occurs at several intervals in the drill core, one of which has a $\mathrm{U}-\mathrm{Pb}$ zircon age of $96.2 \pm 1.0 \mathrm{Ma}$ (Dusel-Bacon and others, 2003). Mineralized rocks at the Champion Creek $\mathrm{Cu}-\mathrm{Pb}-$ $\mathrm{Zn}$-Ag-Au prospects, $13 \mathrm{~km}$ northwest of the Lead Creek prospect (fig. 3), are present at two properties. The Champion I property consists of pyroxene skarn in a roof pendant of Paleozoic biotite schist; Champion II is a stratabound lens of garnet-pyroxene skarn that formed in intercalated marble units within a Paleozoic quartz-mica schist (Nasina assemblage), proximal to Cretaceous or Tertiary dacite to granodiorite intrusive rocks (U.S. Bureau of Mines, 1995). On the basis of the mid-Cretaceous U-Pb age for the felsic porphyry intrusion in the Lead Creek section and the Early to mid-Cretaceous model $\mathrm{Pb}$ ages for galena from the Lead Creek and Champion II prospects, Dusel-Bacon and others (2003) proposed that Lead Creek is an epigenetic, vein and manto-style replacement deposit, distal (and related) to the epigenetic, pluton-related skarn deposits at the Champion I and II prospects.

\section{Little Whiteman Prospect}

The LWM prospect (Light and others, 2008) is in the upper headwaters of Little Whiteman Creek (northern Eagle A-4 quadrangle) in an area of low relief with limited natural exposure. It is typified by a large "kill zone," which is an area of minimal vegetation due to the presence of acidic soils that reflect the weathering of iron sulfides at depth. Diamond drilling, begun in 2006, targeted a gravity high that is coincident with a multielement soil geochemical anomaly. Sulfide zones, as identified in drill cores, are hosted within brecciated carbonate strata that were intruded by fine-grained, mafic igneous rocks; both lithologies are strongly dolomitized (Light and others, 2008). The mineralized zone has a northeast trend and occurs in the hanging wall of a major northeast-striking, east-dipping, high-angle fault, referred to as the Kechumstuk Fault (Cullan Lester, Alaska Earth Sciences, written communication, 2008; fig. 5). This fault is prominent on a series of recently published airborne aeromagnetic and electromagnetic resistivity maps (Burns and others, 2008). Detailed mapping of an area approximately 6 by 9 $\mathrm{km}$ surrounding the LWM prospect has identified several parallel, northeast-striking, east-dipping faults, including the Kechumstuk Fault, and determined displacement to be both normal and sinistral (Cullan Lester, Alaska Earth Sciences, written communication, 2008). Carbonate host rocks at the prospect occur within a down-dropped sliver of greenschist-facies sedimentary and intrusive rocks. Faulted siltstone and argillite also are present within the down-dropped fault block and locally contain pyrite and lesser sphalerite (Cooley, 2007; Light and others, 2008). These greenschist-facies rocks were originally mapped by Foster (1976) as part of her Pzq unit, which included quartzite, marble, phyllite, greenstone, and quartz-graphite and quartz-muscovite schist, chlorite schist, and calcareous schist. Dusel-Bacon and others (2006) interpreted this unit to be part of the Nasina assemblage. 
Diamond drilling by FMM (Cooley, 2007; Light and others, 2008) revealed that hypogene base- and preciousmetal mineralization at LWM comprises disseminated to massive, coarse-grained sphalerite and galena with subordinate pyrite and sparse chalcopyrite and $\mathrm{Sb}-\mathrm{As}-\mathrm{Ag}$ sulfosalts in a quartz-carbonate gangue. Drilling results include $44.6 \mathrm{~m}$ averaging 15.9 percent $\mathrm{Zn}, 5.3$ percent $\mathrm{Pb}$, and $76.6 \mathrm{~g} /$ tonne $\mathrm{Ag}$, and $6.5 \mathrm{~m}$ averaging 31.6 percent $\mathrm{Zn}, 11.3$ percent $\mathrm{Pb}, 1.41$ percent $\mathrm{Cu}$, and $464.2 \mathrm{~g} /$ tonne Ag (Light and others, 2008). As of October, 2008, the LWM prospect has been explored by 60 drill cores, which together delineate two subparallel sulfide-rich zones of carbonate replacement style that have been traced by drilling for over $700 \mathrm{~m}$ of strike length and to greater than $300 \mathrm{~m}$ depth. The extent of the mineralized zones is open in all directions (Full Metal Minerals, USA, Inc., 2008).

Herein we summarize our results from mesoscopic observations, petrographic examination of 10 polished thin sections, and 7 whole-rock geochemical analyses of mineralized samples collected from 2006 and 2007 drill cores. LWM massive sulfides consist of coarse dark brown to black sphalerite, minor to abundant galena, sparse to minor pyrite, and rare to sparse chalcopyrite in a gangue of calcite and lesser quartz (figs. $10 A-10 D)$. In transmitted light, most of the sphalerite is dark reddish-brown and generally unzoned (figs. $10 C$ and $D$ ), although in some samples the sphalerite displays a faint, diffuse zoning. Sphalerite locally has pale yellow rims and discordant zones that are present along cracks and grain boundaries (shown by arrows in fig. $10 \mathrm{C}$ ), which may reflect retrograde alteration. In some samples, sphalerite contains moderate to abundant blebs of dispersed chalcopyrite. This texture ("chalcopyrite disease" of Barton and Bethke, 1987), likely results from replacement of original Fe-bearing sphalerite by an aggregate of chalcopyrite and low-Fe sphalerite during mineralization. Pyrite mainly occurs as disseminated grains (figs. $10 E$ and $F$ ), but, in one sample, also forms a vein. Pyrargyrite $\left(\mathrm{Ag}_{3} \mathrm{SbS}_{3}\right)$, tentatively identified based on its distinctive optical features and the high $\mathrm{Ag}$ and $\mathrm{Sb}$ contents indicated in the whole-rock geochemical analyses for several samples (table 4), is present within, or adjacent to, galena (fig. 10F). The galena also may contain high Ag, as so-called "argentiferous galena," but most if not all of this Ag likely resides in submicroscopic $(<1 \mu \mathrm{m})$ inclusions of Ag sulfosalt minerals, and is not present within the crystal lattice of the galena (Sharp and Buseck, 1993). McLeod (2008) also reports the presence of rare As-Sb-Ag sulfosalts, consistent with the locally elevated As concentrations (as much as $230 \mathrm{ppm}$ ) in our whole-rock geochemical data. The gangue to the sulfides is dominantly quartz and carbonate, in places accompanied by minor chlorite and white mica(?). Some quartz forms euhedral crystals (fig. 10D); carbonate in one sample is euhedral and distinctly zoned.

Whole-rock analyses of seven mineralized samples of drill core from LWM are listed in table 4. Most of these samples contain abundant sphalerite and (or) galena and sparse chalcopyrite in a carbonate-rich gangue. In addition to generally very high contents of $\mathrm{Zn}$ (as much as 51.5 percent) and $\mathrm{Pb}$ (as much as 47.0 percent), the analyses show locally high $\mathrm{Cu}$ (as much as 1.5 percent), $\mathrm{Ag}$ (as much as $730 \mathrm{ppm}$ ), $\mathrm{Cd}$ (as much as 3,450 ppm), and $\mathrm{Sb}$ (as much as 1,100 ppm), plus elevated As (as much as $230 \mathrm{ppm}$ ), In (as much as $67.4 \mathrm{ppm}$ ), and $\mathrm{Hg}$ (as much as $7,240 \mathrm{ppb}$ ). The elevated In that preferentially is present in the Zn-rich samples is especially noteworthy, owing to increasing demand for this rare metal in high-technology products, such as transparent electrodes in liquid-crystal displays and new-generation solar cells (Ragnarsdóttir, 2008). Concentrations of other metals of economic or exploration interest are uniformly low, including for Co ( $\leq 120 \mathrm{ppm}), \mathrm{Ni}(<26 \mathrm{ppm}), \mathrm{Bi}(<9 \mathrm{ppm}), \mathrm{Au}(<2 \mathrm{ppb})$, Mo ( $<2 \mathrm{ppm})$, Se $(<25 \mathrm{ppm})$, Te $(<2 \mathrm{ppm}), \operatorname{Sn}(\leq 16 \mathrm{ppm})$, $\mathrm{W}(<3 \mathrm{ppm}), \mathrm{Tl}(\leq 1 \mathrm{ppm})$, and $\mathrm{U}(<3 \mathrm{ppm})$.

\section{West Little Whiteman Prospect}

The West Little Whiteman (West LWM) prospect is $4 \mathrm{~km}$ southwest of the main LWM prospect (fig. 5) near the headwaters of Little Whiteman Creek. Based on limited outcrops, mineralized rocks at West LWM consist of stratabound to discordant zones of garnet-pyroxene skarn 1 $\mathrm{cm}$ to $\sim 1 \mathrm{~m}$ thick, within calcite marble host rocks $\sim 500 \mathrm{~m}$ from their contact with an undated biotite granite pluton. Some of the small skarn occurrences are mineralogically zoned, with garnet-rich margins and pyroxene- or amphibole-rich cores. Abundant epidote and (or) idocrase occur locally in the skarn assemblages. Disseminated sulfides are present locally, mainly sphalerite with sparse chalcopyrite and pyrite, and traces of galena(?). One sphalerite- and chalcopyrite-bearing outcrop of calc-silicate skarn also contains a $10-\mathrm{cm}$-thick epidote-rich zone with disseminated prismatic black crystals as much as $3 \mathrm{~cm}$ long of the $\mathrm{Ca}-\mathrm{Fe}$ silicate mineral, ilvaite, an uncommon mineral in skarns.

\section{Fish Prospect}

The Fish prospect (Light and others, 2008) is $6 \mathrm{~km}$ northeast of the LWM prospect (figs. 4 and 5) in the 

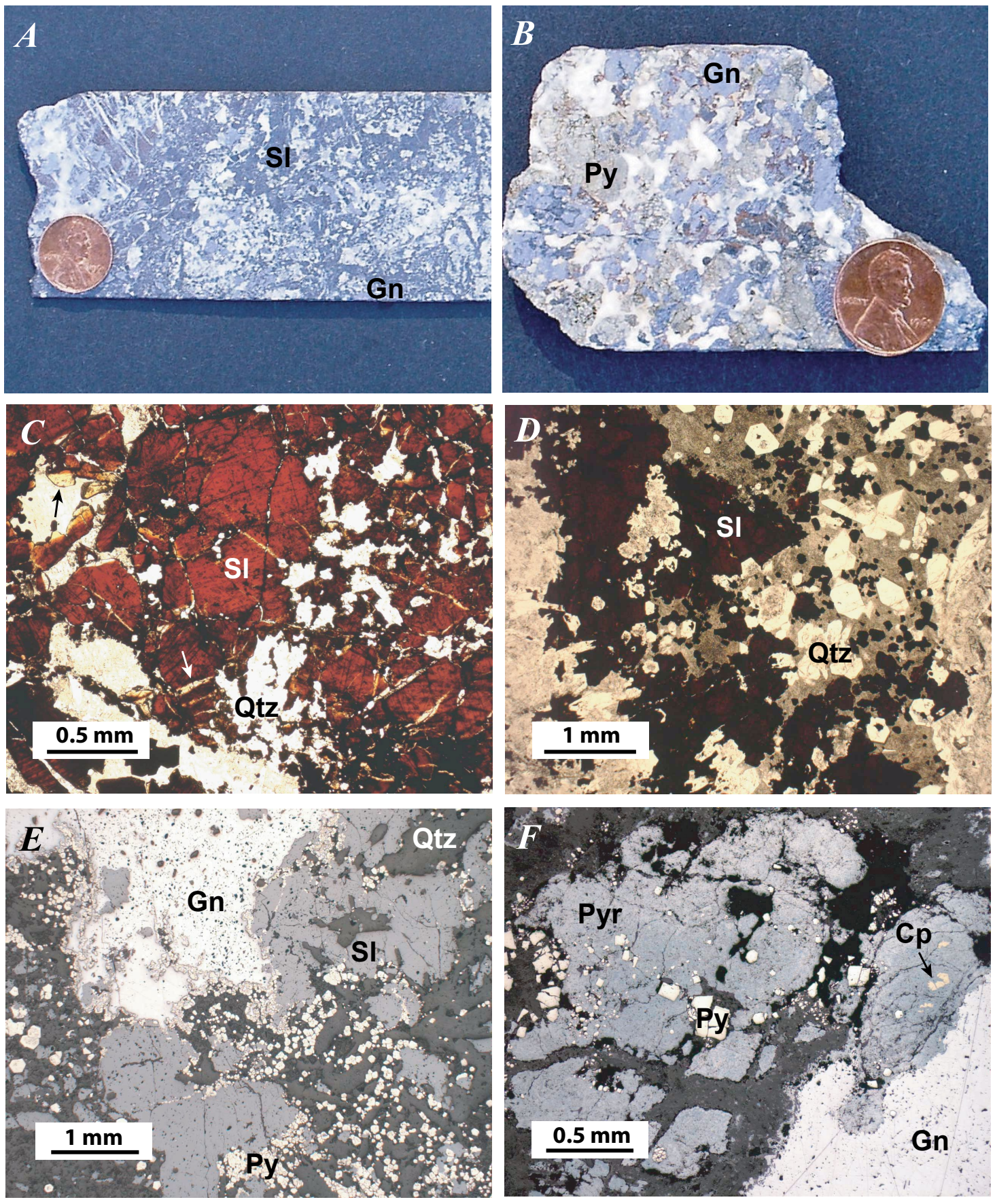

Figure 10. Photographs and photomicrographs showing textural features of Little Whiteman (LWM) drill core. $A$, Coarse dark sphalerite (SI) and minor galena $(\mathrm{Gn})$ in a gangue (white) of calcite and lesser quartz; sample LWM 07-4-107.0 m. B, Coarse galena and pyrite (Py) in a gangue (white) of subequal calcite and quartz; sample LWM 07-19-128 m. C, Massive sphalerite with discordant pale zones in a quartz (Qtz)-carbonate gangue; sample LWM 07-4-107.0 m; transmitted, plane-polarized light. $D$, Sphalerite and minor pyrite in a gangue of fine-grained carbonate and euhedral quartz; sample LWM 07-4-109.0 m; transmitted, plane-polarized light. $E$, Sphalerite and galena with minor disseminated pyrite in a quartz-carbonate gangue; sample LWM 07-4-108.5 m; reflected, plane-polarized light. F, Fine-grained pyrargyrite(?) (Pyr) with pyrite and sparse chalcopyrite (Cp) next to massive galena; sample LWM 07-19-128 m; reflected, plane-polarized light. 
upper reaches of Gold Creek, a southeasterly flowing drainage of the Mosquito Fork of the Fortymile River (southern Eagle B-4 quadrangle). The prospect is deeply weathered and is overlain by an extensive, 15 to 23 $\mathrm{m}$-thick, gossan that extends for 1,500 $\mathrm{m}$ along strike. The gossan is interpreted to derive from an intensely weathered, underlying massive to semi-massive sulfide body (Van Wyck, 2007a; Light and others, 2008). Fish occurs adjacent to several small plutons, one of which yielded an Early Jurassic U-Pb zircon age of $187 \pm 3 \mathrm{Ma}$ (fig. 7). The surrounding metamorphic rocks are at higher metamorphic grade than those associated with the LWM prospect, and they were mapped by Foster (1976) as part of her Pzb unit. This unit includes biotite schist, quartzite, marble, and lesser muscovite schist, quartz-graphite schist, quartz-amphibole schist, greenschist, and interlayered greenstone; locally the unit contains higher-grade garnetiferous rocks, gneiss, amphibolite, and hornfelsic schist and gneiss, but mostly the metamorphic grade is epidote-amphibolite facies (Foster, 1976). Dusel-Bacon and others (2006) interpreted this unit to be part of the Fortymile River assemblage.

Ten diamond drill holes at Fish penetrated a sequence of lower amphibolite-facies metasedimentary, metavolcanic, and carbonate rocks, in which the primary stratigraphy was disrupted by folding and possible thrust faulting during metamorphism (Light and others, 2008). Light and others propose a simplified geometry consisting of a lower plate containing a marble unit and a sulfide zone that is either on top of the marble unit or extends down into it. Structurally overlying the marble is a sequence of quartzite, pelite, and calc-schist, which is overlain by a unit characterized by abundant chlorite schist.

The nature and paragenesis of base-metal mineralized rocks at Fish have yet to be resolved, in part due to the highly oxidized and gossanous nature of the deposit intercepted in drill cores, even at depths of $300 \mathrm{~m}$ (Light and others, 2008). Drilling results from 2006 (Van Wyck, 2007a) suggested that the mineralization is epigenetic, cutting the predominantly metasedimentary sequence, and that it has the geometry of a tabular body dipping $35^{\circ}$ to the west-northwest. No significant sulfide-rich intervals were encountered during 2006 drilling, and most sulfides are oxidized. Some 2006 drill holes intersected strongly oxidized massive sulfide as much as $44 \mathrm{~m}$ thick. Assay results for these zones included $379 \mathrm{~g} /$ tonne $\mathrm{Ag}$ over $1.9 \mathrm{~m}$ and 17.3 percent $\mathrm{Zn}$ over $4.2 \mathrm{~m}$. In addition to oxidized ore, 2006 drilling identified intervals of sphalerite- and magnetite-bearing skarn in holes 6 and 7 and pyrite in holes 5, 6, and 7. Drilling in 2007 confirmed the $35^{\circ}$ dip of the weathered, massive sulfide body and showed it to be compositionally zoned, with Zn-, Ag-, $\mathrm{Au}-, \mathrm{Pb}-$, and $\mathrm{Cu}-$ rich sections (McLeod, 2008; Light and others, 2008), including locally high concentrations of $\mathrm{Bi}, \mathrm{As}$, and $\mathrm{Sb}$. An Ag-rich section of oxidized material in one core averaged $205 \mathrm{~g} /$ tonne Ag over $2.1 \mathrm{~m}$. Zinc-rich zones in this weathered interval include $8.1 \mathrm{~m}$ averaging 12.3 percent $\mathrm{Zn}$, which is present primarily as the zinc carbonate mineral, smithsonite (McLeod, 2008; Light and others, 2008). Such nonsulfide Zn deposits can be attractive exploration targets (for example, Hitzman and others, 2003).

Herein we summarize our results from petrographic examination of nine polished thin sections and nine whole-rock geochemical analyses (table 4) of samples from the magnetite-bearing skarn portions of the 2006 Fish drill core. The majority of our samples are from 124 to $143 \mathrm{~m}$ depth in drill hole 7 from an interval containing scattered pods of sphalerite. Recrystallized marble and calc-silicate assemblages underlie the skarn; drilling terminated at $153.9 \mathrm{~m}$ in marble. Disseminated grains of magnetite are present in most of our Fish thin sections, generally as a major mineral, within a carbonate-quartzpyroxene matrix (fig. 11). Dark red-brown sphalerite forms irregular clots (fig. 11A). Prominent needles of hematite \pm magnetite (fig. $11 B$ ) have apparently replaced preexisting amphibole or a similar prismatic mineral. Locally, magnetite rims grains of unzoned sphalerite, and both the magnetite and sphalerite are partly replaced by chlorite and coarse carbonate (figs. $11 C$ and $D$ ). In one sample from drill hole 7, magnetite is intergrown with abundant pyrrhotite in an amphibole-rich matrix that may include minor amounts of the calcium-aluminum borosilicate, axinite (fig. $11 E$ ). Drill hole 6 at $210.5 \mathrm{~m}$ depth contains abundant pyrite that is brecciated and infilled by fine-grained arsenopyrite (fig. 11F).

Whole-rock analyses of seven variably mineralized (and unweathered) samples of drill core from Fish are listed in table 4. Minor axinite is inferred to be present in amphibole-rich samples from 129.0 and $132.2 \mathrm{~m}$ depths, based on whole-rock analyses that indicate elevated B contents of 286 and $158 \mathrm{ppm}$, respectively, and on the morphological properties of the mineral. One relatively sphalerite-rich sample has 6.6 percent $\mathrm{Zn}$ and $382 \mathrm{ppm}$ $\mathrm{Cd}$, but minimal amounts of other metals including Ag $(<2$ ppm). One pyrite- and arsenopyrite-rich sample (fig. $11 F$ ) is distinctive in that it contains 4.6 percent As, 7.6 ppm Au, 1110 ppm Sb, 730 ppm Ag, and 73 ppm Bi. The remaining five samples from the Fish drill core have the following maximum concentrations: $\mathrm{Zn}(6830 \mathrm{ppm}), \mathrm{Pb}$ (20 ppm), Cu (270 ppm), Ag (3 ppm), Cd (46 ppm), Sb (66 ppm), As (235 ppm), In (44 ppm), and $\mathrm{Hg}$ (24 ppb), Co (71 ppm), Ni (25 ppm), Bi (73 ppm), Au (19 ppb), 
Table 4. Whole-rock chemical analyses of mineralized samples from the Fortymile district, east-central Alaska.

[All analyses by Activation Laboritories, Ancaster, Ontario. Major elements by fusion inductivity coupled-plasma mass spectrometry (ICP-MS) Li, B, Ni, Cd, Bi, Ga, $\mathrm{Se}, \mathrm{Mo}, \mathrm{Ag}, \mathrm{In}, \mathrm{Rb}, \mathrm{Sr}$, by AR-MS and ICP-OES (values $>1 \%$ ); Sc, Cr, Co, As, Sb, Au by instrumental neutron-activation analysis (INAA); Hg by FAA; V, Zr, Hf, Nb, Ta, $\mathrm{Sn}, \mathrm{Ba}, \mathrm{Y}, \mathrm{La}, \mathrm{Nd}, \mathrm{Yb}$, Th, U by fusion ICP-MA. Elements analyzed but below detection: Be $\leq 1 \mathrm{ppm}, \mathrm{Ge}<5 \mathrm{ppm}, \mathrm{Te}<2 \mathrm{ppm}, \mathrm{Cs}<7 \mathrm{ppm}, \mathrm{W}<9 \mathrm{ppm}, \mathrm{Tl} \leq 1 \mathrm{ppm}$. Deposit abbreviation: LWM, Little White Man]

\begin{tabular}{|c|c|c|c|c|c|c|c|c|c|}
\hline Sample No. & $\underline{06-5-112.5}$ & $\underline{06-6-210.5}$ & $\underline{06-7-124.7}$ & $\underline{06-7-124.8}$ & $\underline{06-7-129.0}$ & $\underline{06-7-132.2}$ & $\underline{06-7-142.3}$ & $\underline{06-1-37.0}$ & $\underline{07-4-107.0}$ \\
\hline Deposit & Fish & Fish & Fish & Fish & Fish & Fish & Fish & LWM & LWM \\
\hline \multicolumn{10}{|c|}{ Major elements, in weight percent } \\
\hline $\mathrm{SiO}_{2}$ & 57.09 & 10.62 & 41.74 & 2.54 & 3.98 & 20.29 & 9.68 & 2.77 & 12.76 \\
\hline $\mathrm{Al}_{2} \mathrm{O}_{3}$ & 13.46 & 0.17 & 6.49 & 0.31 & 0.81 & 3.17 & 1.06 & 0.11 & 1.15 \\
\hline $\mathrm{Fe}_{2} \mathrm{O}_{3}{ }^{\mathrm{T}}$ & 6.87 & 50.15 & 8.37 & 9.73 & 10.46 & 20.02 & 12.26 & 13.59 & 12.11 \\
\hline $\mathrm{MnO}$ & 0.300 & 0.546 & 0.542 & 0.238 & 0.292 & 0.272 & 0.385 & 0.225 & 0.422 \\
\hline $\mathrm{MgO}$ & 1.93 & 1.38 & 15.47 & 1.30 & 6.56 & 14.26 & 11.01 & 0.03 & 2.54 \\
\hline $\mathrm{CaO}$ & 12.34 & 5.85 & 20.90 & 45.81 & 40.32 & 19.17 & 26.02 & 0.09 & 5.64 \\
\hline $\mathrm{Na}_{2} \mathrm{O}$ & 0.63 & 0.02 & 0.08 & $<0.01$ & $<0.01$ & 0.05 & 0.02 & $<0.01$ & 0.04 \\
\hline $\mathrm{K}_{2} \mathrm{O}$ & 1.65 & 0.06 & $<0.01$ & $<0.01$ & $<0.01$ & 0.47 & $<0.01$ & $<0.01$ & 0.15 \\
\hline $\mathrm{TiO}_{2}$ & 0.556 & 0.008 & 0.561 & 0.023 & 0.295 & 0.107 & 0.017 & 0.004 & 0.016 \\
\hline $\mathrm{P}_{2} \mathrm{O}_{5}$ & 0.05 & $<0.01$ & 0.17 & $<0.01$ & $<0.01$ & $<0.01$ & 0.01 & $<0.01$ & $<0.01$ \\
\hline LOI & 3.19 & 29.12 & 3.13 & 29.55 & 30.27 & 13.40 & 13.73 & 15.20 & 12.29 \\
\hline Total & 98.06 & 97.92 & 97.46 & 89.47 & 92.97 & 91.23 & 74.20 & 31.98 & 47.11 \\
\hline $\mathrm{CO}_{2}$ & 2.70 & 5.04 & 2.72 & 40.2 & 36.9 & 17.5 & 28.8 & 0.25 & 10.1 \\
\hline \multicolumn{10}{|c|}{ Trace elements, in parts per million } \\
\hline $\mathrm{Li}$ & 13.6 & 0.8 & 15.2 & 0.5 & 3.9 & 9.6 & 9.3 & 0.3 & 0.8 \\
\hline $\mathrm{B}$ & 2 & 1 & 6 & 12 & 286 & 158 & 76 & 1 & 1 \\
\hline $\mathrm{Sc}$ & 16.9 & 0.6 & 13.8 & 0.3 & 2.8 & 3.1 & 1.5 & 0.3 & 0.5 \\
\hline $\mathrm{V}$ & 94 & 8 & 40 & 14 & 33 & 66 & $<5$ & $<5$ & 10 \\
\hline $\mathrm{Cr}$ & 5 & $<5$ & 120 & $<5$ & 6 & 20 & 22 & 31 & 27 \\
\hline $\mathrm{Zr}$ & 80 & 4 & 104 & 10 & 77 & 10 & 9 & 2 & 7 \\
\hline $\mathrm{Hf}$ & 2.4 & $<0.1$ & 2.7 & 0.2 & 2.0 & 0.3 & 0.3 & $<0.1$ & 0.2 \\
\hline $\mathrm{Nb}$ & 8.8 & 1.3 & 3.4 & 1.3 & 6.4 & 4.1 & 0.6 & $<0.2$ & $<0.2$ \\
\hline $\mathrm{Ta}$ & 0.35 & 0.01 & 0.47 & 0.01 & 0.56 & 0.10 & 0.03 & $<0.01$ & 0.02 \\
\hline Co & 4 & 32 & 4 & 2 & 3 & 71 & 100 & 120 & 74 \\
\hline $\mathrm{Ni}$ & 3.3 & 9.5 & 7.7 & 4.6 & 21.6 & 24.7 & 20.2 & 0.8 & 8.2 \\
\hline $\mathrm{Cu}(\%)$ & $<0.001$ & 0.104 & 0.001 & 0.003 & $<0.001$ & 0.027 & 0.053 & 0.136 & 0.472 \\
\hline $\mathrm{Zn}(\%)$ & 0.024 & 0.025 & 0.314 & 0.150 & 0.063 & 0.683 & 6.61 & 51.5 & 22.2 \\
\hline $\mathrm{Cd}$ & 0.91 & 0.80 & 15.2 & 10.4 & 3.18 & 46.0 & 382 & 3,450 & 1,480 \\
\hline $\mathrm{Pb}(\%)$ & $<0.001$ & 0.028 & 0.002 & $<0.001$ & $<0.01$ & 0.002 & $<0.001$ & 0.140 & 14.6 \\
\hline $\mathrm{Bi}$ & 0.06 & 73.2 & 2.18 & 0.09 & 0.42 & 11.4 & 1.60 & 0.17 & 0.44 \\
\hline $\mathrm{Ga}$ & 6.93 & 0.14 & 5.23 & 0.74 & 1.87 & 4.76 & 2.06 & 4.38 & 2.06 \\
\hline As & 9.0 & 45,700 & 235 & 10.4 & 16.9 & 36.6 & 82.2 & 38.7 & 93.4 \\
\hline $\mathrm{Sb}$ & 3.0 & 1,110 & 9.6 & 0.4 & 63.6 & 14.0 & 14.0 & 19.5 & 250 \\
\hline $\mathrm{Au}(\mathrm{ppb})$ & $<2$ & 7,600 & 19 & 5 & $<2$ & $<2$ & $<2$ & $<2$ & $<2$ \\
\hline $\mathrm{Hg}(\mathrm{ppb})$ & $<5$ & 112 & 10 & 10 & 7 & 24 & 101 & 7,240 & 2,050 \\
\hline $\mathrm{Se}$ & 0.2 & 0.3 & 0.4 & 1.4 & 0.4 & 4.0 & 16.9 & 12.0 & 4.0 \\
\hline Mo & 115 & 15.1 & 0.45 & 0.79 & 0.33 & 0.18 & 0.12 & 0.48 & 0.23 \\
\hline $\mathrm{Ag}$ & 0.25 & 730 & 2.91 & 0.28 & 0.15 & 2.17 & 1.61 & 19.4 & 190 \\
\hline In & 0.34 & 0.23 & 0.20 & 0.14 & 0.17 & 43.8 & 2.34 & 67.4 & 19.7 \\
\hline $\mathrm{Sn}$ & 17 & 2 & 33 & 5 & 18 & 186 & 50 & 15 & 3 \\
\hline $\mathrm{Rb}$ & 1.9 & 0.5 & 2.0 & 0.3 & 0.5 & 68.4 & 0.9 & 0.5 & 1.6 \\
\hline $\mathrm{Sr}$ & 150 & 74.2 & 25.5 & 103 & 138 & 68.5 & 104 & 1.1 & 41.8 \\
\hline $\mathrm{Ba}$ & 852 & 9 & 17 & 5 & 22 & 137 & 13 & $<3$ & 26 \\
\hline $\mathrm{Y}$ & 24.9 & 1.3 & 11.7 & 1.5 & 1.8 & 14.1 & 16.8 & $<0.5$ & 1.9 \\
\hline $\mathrm{La}$ & 8.09 & 0.66 & 4.40 & 1.90 & 3.90 & 23.5 & 7.47 & 0.13 & 0.78 \\
\hline $\mathrm{Nd}$ & 12.7 & 0.34 & 6.34 & 0.74 & 1.24 & 10.5 & 3.05 & 0.09 & 0.77 \\
\hline $\mathrm{Yb}$ & 2.55 & 0.10 & 0.71 & 0.10 & 0.11 & 0.76 & 1.83 & $<0.01$ & 0.15 \\
\hline Th & 1.00 & 0.09 & 2.52 & 0.09 & 0.08 & 0.59 & 0.82 & $<0.05$ & 0.15 \\
\hline $\mathrm{U}$ & 2.36 & 10.4 & 1.02 & 0.21 & 1.65 & 1.21 & 0.81 & 0.92 & 0.62 \\
\hline
\end{tabular}


Table 4. Whole-rock chemical analyses of mineralized samples from the Fortymile district, east-central Alaska-Continued.

\begin{tabular}{|c|c|c|c|c|c|c|c|c|c|}
\hline Sample No. & $\underline{07-4-108.5}$ & $\underline{07-4-109.0}$ & $\underline{07-4-109.4}$ & $\underline{07-19-128}$ & $\underline{07-19-132.5}$ & $\underline{07 \mathrm{Adb} 02 \mathrm{~A}}$ & $\underline{07 \mathrm{Adb} 02 \mathrm{~B}}$ & $\underline{07 \mathrm{Adb} 02 \mathrm{C}}$ & $\underline{07 \mathrm{Adb} 03}$ \\
\hline Deposit & LWM & LWM & LWM & LWM & LWM & Oscar & Oscar & Oscar & Eva Creek \\
\hline \multicolumn{10}{|c|}{ Major elements, in weight percent } \\
\hline $\mathrm{SiO}_{2}$ & 11.20 & 17.35 & 12.03 & 3.43 & 4.85 & 19.52 & 11.24 & 17.77 & 28.58 \\
\hline $\mathrm{Al}_{2} \mathrm{O}_{3}$ & 1.44 & 2.31 & 1.61 & 2.57 & 0.60 & 37.28 & 0.90 & 0.92 & 0.46 \\
\hline $\mathrm{Fe}_{2} \mathrm{O}_{3}{ }^{\mathrm{T}}$ & 6.97 & 9.99 & 9.08 & 15.59 & 7.45 & 25.63 & 54.41 & 71.59 & 1.11 \\
\hline $\mathrm{MnO}$ & 0.152 & 0.235 & 0.269 & 0.146 & 0.160 & 0.276 & 0.200 & 0.212 & 0.413 \\
\hline $\mathrm{MgO}$ & 0.68 & 1.10 & 1.34 & 0.56 & 1.00 & 4.02 & 2.04 & 3.42 & 0.16 \\
\hline $\mathrm{CaO}$ & 1.47 & 2.50 & 3.01 & 3.45 & 2.48 & 5.29 & 4.96 & 5.90 & 0.25 \\
\hline $\mathrm{Na}_{2} \mathrm{O}$ & 0.07 & $<0.01$ & $<0.01$ & 0.10 & 0.09 & 0.23 & 0.03 & 0.05 & $<0.01$ \\
\hline $\mathrm{K}_{2} \mathrm{O}$ & 0.21 & 0.25 & 0.20 & 0.45 & 0.10 & 0.13 & $<0.01$ & $<0.01$ & 0.09 \\
\hline $\mathrm{TiO}_{2}$ & 0.045 & 0.044 & 0.027 & 0.080 & 0.027 & 0.096 & 0.036 & 0.067 & 0.009 \\
\hline $\mathrm{P}_{2} \mathrm{O}_{5}$ & 0.03 & 0.05 & $<0.01$ & 0.02 & $<0.01$ & 0.16 & 1.00 & 0.05 & 0.02 \\
\hline LOI & 8.95 & 14.87 & 13.26 & 9.09 & 7.08 & 6.47 & 21.12 & -1.23 & 19.98 \\
\hline Total & 31.22 & 48.68 & 40.80 & 35.48 & 23.84 & 99.10 & 95.94 & 98.75 & 51.07 \\
\hline $\mathrm{CO}_{2}$ & 2.34 & 4.62 & 5.82 & 2.61 & 3.83 & 0.01 & $<0.01$ & 0.01 & 18.8 \\
\hline \multicolumn{10}{|c|}{ Trace elements, in parts per million } \\
\hline $\mathrm{Li}$ & 0.7 & 1.2 & 0.9 & 0.8 & 0.3 & 9.9 & 7.1 & 3.4 & 0.7 \\
\hline $\mathrm{B}$ & 1 & 1 & 1 & 1 & $<1$ & 6 & 1 & 8 & 3 \\
\hline $\mathrm{Sc}$ & 0.7 & 1.4 & 1.9 & 2.2 & 0.5 & 0.7 & 0.5 & 1.5 & 0.4 \\
\hline $\mathrm{V}$ & 12 & 22 & 19 & 23 & 8 & 22 & 38 & 27 & 7 \\
\hline $\mathrm{Cr}$ & $<5$ & $<5$ & $<5$ & 22 & $<5$ & 11 & 9 & 13 & $<5$ \\
\hline $\mathrm{Zr}$ & 12 & 10 & 11 & 22 & 8 & 24 & 4 & 3 & 4 \\
\hline $\mathrm{Hf}$ & 0.3 & 0.2 & 0.3 & 0.6 & 0.2 & 1.0 & $<0.1$ & 0.1 & 0.1 \\
\hline $\mathrm{Nb}$ & 0.7 & 0.7 & 0.4 & 1.2 & 0.9 & 2.5 & 0.3 & 0.3 & 0.3 \\
\hline $\mathrm{Ta}$ & 0.05 & 0.05 & 0.03 & 0.08 & 0.09 & 0.17 & 0.03 & 0.05 & 0.02 \\
\hline $\mathrm{Co}$ & 34 & 110 & 120 & 56 & 65 & 260 & 273 & 4 & 6 \\
\hline $\mathrm{Ni}$ & 4.1 & 5.9 & 4.1 & 25.6 & 10.8 & 44.8 & 28.9 & 7.2 & 1.7 \\
\hline $\mathrm{Cu}(\%)$ & 0.140 & 0.138 & 0.116 & 1.490 & 0.583 & 0.170 & 0.377 & 0.001 & 0.166 \\
\hline $\mathrm{Zn}(\%)$ & 20.1 & 34.0 & 37.1 & 2.06 & 21.4 & 0.032 & 0.015 & 0.001 & 25.7 \\
\hline $\mathrm{Cd}$ & 1270 & 1920 & 2110 & 117 & 1380 & 2.05 & 1.23 & 0.06 & 1,880 \\
\hline $\mathrm{Pb}(\%)$ & 38.1 & 2.34 & 0.686 & 47.0 & 41.2 & 0.033 & 0.002 & $<0.001$ & 11.1 \\
\hline $\mathrm{Bi}$ & 8.03 & 1.51 & 0.36 & 4.33 & 5.90 & 13.4 & 17.8 & 3.21 & 1.28 \\
\hline $\mathrm{Ga}$ & 1.95 & 3.73 & 4.72 & 0.75 & 2.03 & 3.69 & 10.4 & 14.6 & 1.92 \\
\hline As & 52.3 & 133 & 94.1 & 230 & 100 & 10.2 & 2.8 & 6.1 & 47.6 \\
\hline $\mathrm{Sb}$ & 273 & 150 & 160 & 1100 & 660 & 6.3 & 1.0 & 1.9 & 450 \\
\hline $\mathrm{Au}(\mathrm{ppb})$ & $<2$ & $<2$ & $<2$ & $<2$ & $<2$ & 19 & $<2$ & $<2$ & $<2$ \\
\hline $\mathrm{Hg}(\mathrm{ppb})$ & 2,930 & 5,610 & 7,190 & 326 & 2,530 & $<5$ & $<5$ & $<5$ & 1,030 \\
\hline $\mathrm{Se}$ & 24.3 & 19.5 & 22.1 & 12.8 & 19.9 & 9.6 & 0.6 & 0.4 & 1.4 \\
\hline Mo & 0.42 & 0.32 & 0.36 & 0.51 & 1.12 & 0.62 & 0.29 & 0.12 & 0.62 \\
\hline $\mathrm{Ag}$ & 350 & 92.4 & 74.3 & 730 & 420 & 7.86 & 9.63 & 0.16 & 200 \\
\hline In & 25.8 & 46.7 & 58.1 & 2.10 & 23.1 & 0.28 & 0.48 & 0.15 & 0.27 \\
\hline $\mathrm{Sn}$ & 10 & 5 & 4 & 17 & 9 & 19 & 23 & 12 & 7 \\
\hline $\mathrm{Rb}$ & 1.4 & 2.6 & 2.2 & 3.5 & 0.7 & 0.9 & 1.1 & 0.5 & 2.0 \\
\hline $\mathrm{Sr}$ & 16.4 & 33.4 & 33.7 & 29.5 & 16.9 & 18.6 & 7.7 & 9.2 & 50.1 \\
\hline $\mathrm{Ba}$ & 28 & 15 & 165 & 144 & 29 & 2998 & 3 & 10 & 66 \\
\hline $\mathrm{Y}$ & 1.5 & 2.2 & 2.0 & 2.8 & 1.3 & 3.1 & 5.7 & 4.2 & 3.8 \\
\hline $\mathrm{La}$ & 5.37 & 6.99 & 2.23 & 1.26 & 1.00 & 2.89 & 0.90 & 0.47 & 2.95 \\
\hline $\mathrm{Nd}$ & 2.69 & 3.15 & 1.33 & 1.21 & 0.89 & 1.99 & 1.12 & 0.44 & 1.48 \\
\hline $\mathrm{Yb}$ & 0.13 & 0.17 & 0.19 & 0.29 & 0.12 & 0.35 & 0.25 & 0.31 & 0.19 \\
\hline $\mathrm{Th}$ & 0.73 & 0.87 & 0.39 & 0.55 & 0.33 & 0.95 & 0.27 & 0.16 & 0.26 \\
\hline $\mathrm{U}$ & 1.32 & 0.97 & 1.00 & 2.56 & 1.90 & 0.86 & 0.37 & 0.28 & 1.49 \\
\hline
\end{tabular}



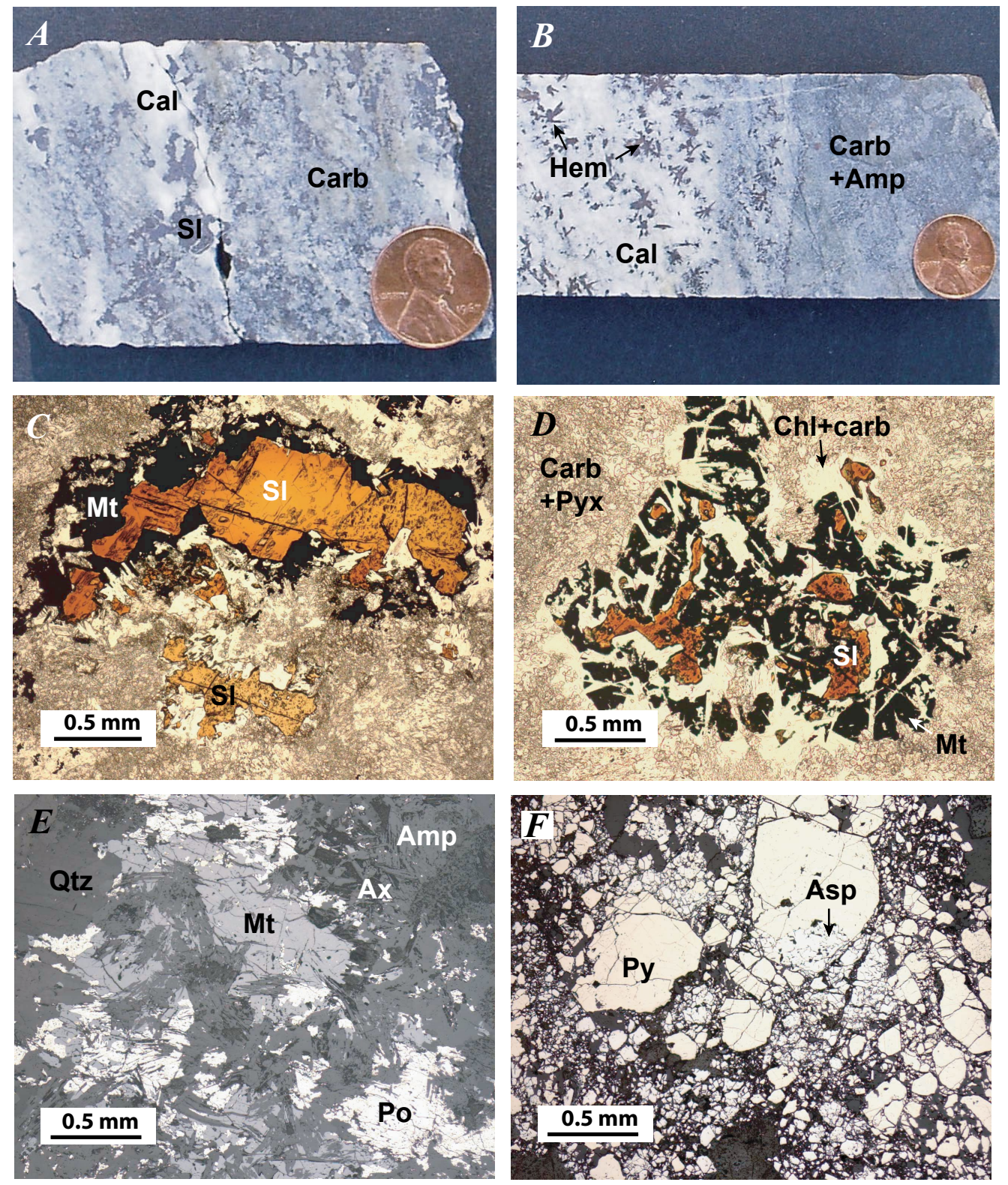

Figure 11. Photos and photomicrographs of Fish prospect drill core. A, Photo of Fish drill core showing dark brown sphalerite (SI) in fine- to coarse-grained calcite (Cal) and carbonate (Carb); minor amounts of pyrite (not visible) are intergrown with the sphalerite; sample Fish 06-7-142.3m. $B$, Photo of Fish drill core showing dark brownish-black needles of hematite (Hem) and sparse magnetite (not visible) in a matrix of fine- to coarse-grained carbonate with minor amphibole (Amp); hematite needles have replaced a pre-existing amphibole or a morphologically similar mineral, possibly axinite; sample Fish 06-7-129.0m. $C$, Photomicrograph of Fish drill core sample showing unzoned sphalerite rimmed by magnetite (Mt) in a fine-grained carbonate-rich gangue; sample Fish 06-7-124.7m; transmitted, plane-polarized light. $D$, Photomicrograph of Fish drill core sample showing red-brown sphalerite surrounded by formerly euhedral magnetite in a matrix of fine-grained carbonate and pyroxene (Pyx); bladed chlorite (Chl) and coarse carbonate of probable retrograde origin replace both the magnetite and sphalerite; sample Fish 06-7$124.7 \mathrm{~m}$; transmitted, plane-polarized light. $E$, Photomicrograph of Fish drill core sample showing magnetite intergrown with pyrrhotite (Po) and sparse pyrite; amphibole and axinite(?) (Ax) gangue; sample Fish 06-7-132.2m; reflected, plane-polarized light. F, Brecciated coarse pyrite infilled by arsenopyrite (Asp) in a quartz-carbonate-silic ate gangue; sample Fish 06-6-210.5m; reflected, plane-polarized light. 
Mo (115 ppm), Se (4 ppm), Te (0.4 ppm), Sn (186 ppm), $\mathrm{W}(9 \mathrm{ppm}), \mathrm{Tl}(1 \mathrm{ppm})$, and U (2 ppm).

\section{Oscar and Nearby Prospects}

The Oscar prospect is on the eastern edge of a northfacing valley, at the headwaters of an unnamed tributary of Gold Bottom Creek, in the northwestern part of the Eagle A-5 quadrangle. Previous work on the prospect, prior to 2006 exploration by FMM, showed anomalous $\mathrm{Au}, \mathrm{Ag}, \mathrm{Pb}$, and $\mathrm{Zn}$ concentrations in soil and rock samples (Werdon and others, 2004, and references therein). A ground magnetometer survey, conducted by Doyon, Ltd., reportedly showed strong evidence for blind skarns at depth (Werdon and others, 2004). Geologic mapping at the prospect, conducted for FMM in 2007 (Lester, 2007), identified multiple layers of both calcic and dolomitic marble in a sequence of amphibolite-facies quartzite, hornblende gneiss, felsic metaigneous rocks, and minor quartz-mica schist. This sequence of metamorphic rocks is part of the same sequence that occurs at the Fish prospect [Pzb unit of Foster (1976); Fortymile River assemblage of Dusel-Bacon and others (2002)]. Almost all mineralized rocks at Oscar are limited to the marble layers (Lester, 2007; Light and others, 2008), which, together with associated metamorphic rocks, are intruded along their southern and western margins by stocks, dikes, and sills of the Early Jurassic syenite of Mount Veta (Foster, 1976). The Mount Veta pluton is texturally and compositionally recognizable by its large K-feldspar megacrysts present in the hornblende-syenite porphyry. Undated, fine- to medium-grained, equigranular granitic to monzogranitic intrusive rocks of presumed Tertiary or Mesozoic age truncate the marble layers along their northern contact (fig. 4).

Base- and precious-metal showings at the Oscar prospect are interpreted by FMM geologists to be marblehosted skarn occurrences that are spatially related to the stocks, dikes, and sills of the megacrystic syenite of Mount Veta (Lester, 2007; McLeod, 2008; Light and others, 2008). Mapped structures at the property include prospectscale folds and northeast- and north-south-striking faults (Lester, 2007). Opaque minerals are chiefly massive magnetite and pyrrhotite with, in decreasing order of abundance, chalcopyrite, bornite sphalerite, and galena (Light and others, 2008). Assays of samples from the topographically higher of two chalcopyrite-magnetite mineralized zones contain as much as 2.3 percent $\mathrm{Cu}$, averaging 0.6 percent, and as much as $356 \mathrm{~g} /$ tonne $\mathrm{Ag}$, averaging $30.7 \mathrm{~g} /$ tonne; samples from the lower zone also have as much as 1.2 percent $Z$ n. Rock samples at the Oscar prospect also contain elevated concentrations of $\mathrm{Au}$ and $\mathrm{Pb}$ (Light and others, 2008). The predominant skarn gangue mineral is actinolite, with subordinate to minor Fe-rich clinopyroxene, epidote, garnet, and calcite \pm quartz (Light and others, 2008).

Petrographic examination of four surface samples from the lower mineralized zone reveals abundant pyrrhotite, minor chalcopyrite, and sparse pyrite in a gangue dominated by pyroxene (probably mainly hedenbergite or hedenbergite-diopside in composition), amphibole (tremolite-actinolite), and chlorite, locally with sparse feldspar and quartz (figs. $12 A$ and $B$ ). Abundant magnetite was found in some creek exposures at the prospect, and in one thin section (fig. 12B). Trace amounts of an Ag-Bi-S sulfosalt, either matildite $\left(\mathrm{AgBiS}_{2}\right)$ or pavonite $\left(\mathrm{Ag}_{2} \mathrm{~S}_{3} \mathrm{Bi}_{2} \mathrm{~S}_{3}\right)$, were identified by using SEM linked with semiquantitative energy-dispersive X-ray spectra (EDS) analysis. The sulfosalt is present as subequant and needlelike grains 5 to 10 microns in length, along gangue-filled cracks between grains (fig. 12C). Pyrrhotite generally is extensively weathered, and in one thin section shows "birds eye" texture that consists of semicircular, concentrically zoned shells composed of pyrite and mixtures of pyrite and marcasite that developed along fractures (Ramdohr, 1969) and as partial replacements of pyrrhotite (fig. 12C).

Whole-rock analyses are available for only three mineralized samples from the Oscar prospect (table 4). Results show minor $\mathrm{Cu}$ (as much as 0.4 percent) but only sparse $\mathrm{Zn}(<0.1$ percent), $\mathrm{Pb}(<0.1$ percent), $\mathrm{Co}(<275 \mathrm{ppm})$, and $\mathrm{Ag}(<10 \mathrm{ppm})$. All three samples contain negligible amounts of $\mathrm{Ni}(<45 \mathrm{ppm}), \mathrm{Cd}(\leq 2 \mathrm{ppm}), \mathrm{Bi}(<18 \mathrm{ppm}), \mathrm{As}$ ( $<11 \mathrm{ppm}), \mathrm{Sb}(<3 \mathrm{ppm}), \mathrm{Au}(<20 \mathrm{ppb}), \mathrm{Hg}(<5 \mathrm{ppb}), \mathrm{Se}$ $(<10 \mathrm{ppm}), \mathrm{Te}(<1 \mathrm{ppm})$, Mo ( $<1 \mathrm{ppm})$, In ( $<1 \mathrm{ppm}), \mathrm{Tl}$ $(<1 \mathrm{ppm})$, Sn $(<20 \mathrm{ppm}), \mathrm{W}(<6 \mathrm{ppm})$, and $\mathrm{U}(\leq 13 \mathrm{ppm})$ Lester (2007) mapped several other skarn occurrences in the Oscar area, all of which are within carbonate strata along or near contacts with the Jurassic syenite of Mount Veta. Some of these skarns also are close to the contact with an undated granitic pluton, $\sim 300 \mathrm{~m}$ northeast of the main Oscar prospect. Calc-silicate skarn at one of the nearby occurrences, $\sim 400 \mathrm{~m}$ west of the main prospect, consists of minor to abundant pyrite, pyrrhotite, and chalcopyrite with sparse to minor sphalerite and rare galena, in a garnet-pyroxene-amphibole gangue. A different occurrence, $\sim 500 \mathrm{~m}$ south of the prospect, comprises laminations, layers, and discordant veins of massive magnetite and amphibole with sparse chalcopyrite and bornite(?); margins of an adjacent syenite dike or sill contain an epidote-rich endoskarn assemblage. A talus boulder of massive sulfide, $200 \mathrm{~m}$ to the west, consists mostly of chalcopyrite with minor pyrrhotite in a fine-grained amphibole gangue. 

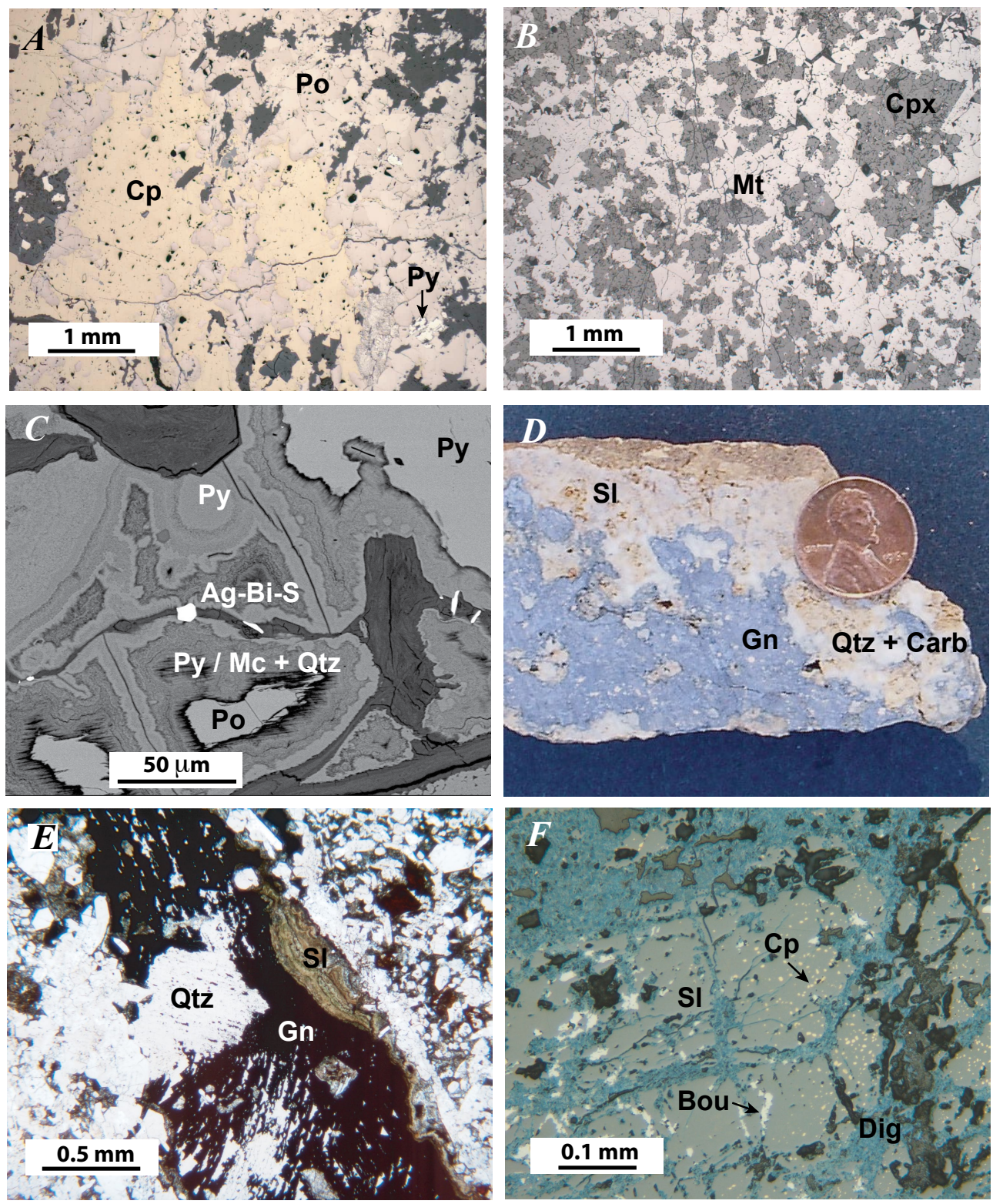

Figure 12. Photos and photomicrographs showing textural features of surface samples from the Oscar and Eva Creek prospects. $A$, Photomicrograph of Oscar sample showing massive pyrrhotite (Po) and chalcopyrite ( $\mathrm{Cp}$ ) with sparse pyrite (Py) in a silicate gangue; sample 07ADb02A; reflected, plane-polarized light. $B$, Photomicrograph of Oscar sample showing intergrown magnetite (Mt) and Fe-pyroxene (probably ferrosalite or hedenbergite; Cpx); sample 07ADb02C; reflected, plane-polarized light. C, SEM backscattered electron image from 0 scar sample showing replacement of pyrrhotite by concentric bands of pyrite and pyrite-marcasite (Mc) plus quartz (Qtz) along cracks and grain boundaries; bright white grains of an $\mathrm{Ag}$-Bi$S$ sulfosalt occur scattered along cracks, now filled by gangue; sample 07ADb02A. $D$, Photo of cut slab from the Eva Creek prospect showing massive galena $(\mathrm{Gn})$ and pale orange sphalerite (SI) in a white gangue of quartz and minor carbonate (Carb); sample 07ADb03. E, Photomicrograph of Eva Creek sample showing galena rimmed by concentrically banded sphalerite surrounded by gangue of euhedral quartz (white), and zinc carbonate (brown and gray); sample 07ADb03B; transmitted, plane-polarized light. $F$, Photomicrograph of Eva Creek sample showing sphalerite grain containing minute blebs of chalcopyrite (yellow dots), short veinlets and fracture fillings of boulangerite(?) (Bou), and extensively developed veinlets and patches of a blue, copper sulfide (digenite?) (Dig); sample 07ADb03A; reflected, plane-polarized light. 


\section{Eva Creek Prospect}

The Eva Creek Ag-Zn-Pb-Cu prospect is $22 \mathrm{~km}$ southwest of the LWM prospect and just north of Eva Creek, a tributary to the Middle Fork of the Fortymile River (fig. 4). Mineralized rock consists of argentiferous galena, cerussite, sphalerite, chalcopyrite, azurite, and malachite in vug fillings, boxworks, and quartz veins in marble (Carter, 1981). Associated with the marble are amphibolite-facies quartz-biotite gneiss and schist, quartz-graphite schist, quartzite, amphibolite, greenstone, and greenschist (Foster and Clark, 1970) included in the Fortymile River assemblage (DuselBacon and others, 2002). The prospect is within $1.5 \mathrm{~km}$ of the Mount Veta pluton to the east (fig. 4). The pluton is epidotized and locally altered along its contact with the Fortymile River assemblage country rocks; a few dikes and small granitic masses, assumed to be mostly diorite and syenite, and quartz veins, are present in the metamorphic country rock west of the contact (Foster and Clark, 1970). Some of the quartz veins are as much as $1 \mathrm{~m}$ thick, are commonly fractured and stained with hematite, and contain pods of partly oxidized galena (Wedow and others, 1954). A single drill hole at the Eva Creek prospect intersected pyrite- and magnetitebearing biotite schist and calcite-filled breccia zones as much as $18 \mathrm{~m}$ thick (Dashevsky and others, 1986). Fourteen samples of partially oxidized marble containing coarse-grained massive sphalerite, galena, and chalcopyrite were collected over a $50 \mathrm{~m}$ by $50 \mathrm{~m}$ area of rubble crop during 2007 exploration by Full Metal Minerals, USA, Inc. These samples averaged 23.6 percent $\mathrm{Zn}, 12.6$ percent $\mathrm{Pb}, 957 \mathrm{~g} /$ tonne $\mathrm{Ag}$, and 0.9 percent $\mathrm{Cu}$, with maximum contents of 43.6 percent $\mathrm{Zn},>25$ percent $\mathrm{Pb}, 3,730 \mathrm{~g} /$ tonne $\mathrm{Ag}$, and 4.9 percent $\mathrm{Cu}$ (Light and others, 2008).

Polished thin sections from three grab samples we collected at the Eva prospect contain coarse (1-2-cmlong) clots of galena, smaller (0.5-1-cm-long) patches and pods of amber sphalerite, and sparse pyrite in a gangue of quartz and carbonate (fig. 12D). Some sphalerite and galena grains have a rounded to oval shape. Sprays of secondary malachite, enveloped by a network of reddish-brown zinc oxide and iron oxide, fill irregularly shaped areas within the gangue. Petrographic examination shows zonation of some galena grains, with more porous cores and massive margins. In transmitted light, sphalerite locally displays growth zoning where it rims galena (fig. 12E). Sphalerite contains moderate to abundant blebs of dispersed chalcopyrite ("chalcopyrite disease"); many grains of sphalerite enclose a fibrous to acicular, blue-green $\mathrm{Cu}$-rich min- eral that is present along fractures and grain boundaries (fig. $12 F$ ); optical properties suggest digenite $\left(\mathrm{Cu}_{9} \mathrm{~S}_{5}\right)$, or possibly chalcocite $\left(\mathrm{Cu}_{2} \mathrm{~S}\right)$. Other fractures within sphalerite grains are filled with galena and another mineral (fig. $12 F$ ), which based on bright gray reflectance and presence of major $\mathrm{Pb}, \mathrm{Sb}$, and $\mathrm{S}$ peaks on SEM-EDS spectra, may be boulangerite ( $\mathrm{PbSbS}$ ).

One whole-rock analysis is available for a sample consisting of partly oxidized massive galena and sparse sphalerite in a quartz-rich gangue. High concentrations exist for $\mathrm{Zn}$ (25.7 percent), $\mathrm{Pb}$ (11.1 percent), $\mathrm{Cu}$ (0.2 percent), Cd (1880 ppm), Ag (200 ppm), Sb (313 $\mathrm{ppm})$, and $\mathrm{Hg}(1,030 \mathrm{ppb})$. This high $\mathrm{Zn}$ content in this relatively sphalerite-poor sample, together with high $\mathrm{CO}_{2}$ (18.8 percent), low $\mathrm{Fe}_{2} \mathrm{O}_{3}$ (1.1 percent), and very low $\mathrm{CaO}, \mathrm{MgO}$, and $\mathrm{MnO}$ (all $<0.5$ percent), suggest the presence of abundant secondary smithsonite. Other metals of economic or exploration interest, including Co (6 ppm), Ni (2 ppm), Bi (1 ppm), As (48 ppm), Au (<2 ppb), Mo (<1 ppm), Se (1 ppm), Te (<1 ppm), In $(<1 \mathrm{ppm}), \mathrm{Sn}(7 \mathrm{ppm}), \mathrm{W}(<1 \mathrm{ppm}), \mathrm{Tl}(<1 \mathrm{ppm})$, and $\mathrm{U}$ $(<2 \mathrm{ppm})$, have uniformly low concentrations.

\section{Mitchell Prospect}

The Mitchell prospect is on a hilltop $8 \mathrm{~km}$ eastsoutheast of the Eva Creek prospect and $2 \mathrm{~km}$ south of Kechumstuk Creek (fig. 5). Mineralized rock consists of sulfides in calc-silicate skarn and silicified marble, $<100 \mathrm{~m}$ from outcrops of an undated granodiorite pluton. Felsic dikes of uncertain age cut the pendant; their relation to mineralization is unknown (U.S. Bureau of Mines, 1995). The skarn is hosted in a marble-rich section of a 1,500-m-long by 150 - to $300-\mathrm{m}$-wide roof pendant (Saunders, 1962). Bornite is a dominant primary sulfide, present as disseminations and in massive lenses as much as $3 \mathrm{~cm}$ thick; pyrrhotite, sphalerite, and chalcopyrite are typically volumetrically minor. WGM, Inc., (1998) also reported the presence of magnetite, galena, and tetrahedrite. The calc-silicate gangue comprises pyroxene, amphibole, and garnet, with locally abundant epidote. Secondary copper minerals (for example, malachite) are present in places. A grab sample of borniterich garnet skarn contains 6.5 percent $\mathrm{Cu}, 1,020 \mathrm{ppb} \mathrm{Au}$, $9 \mathrm{ppm} \mathrm{Te}, 230 \mathrm{~g} /$ tonne Ag, 178 ppm Pb, 208 ppm Zn, $>2,000 \mathrm{ppm} \mathrm{Bi}, 53 \mathrm{ppm}$ As, $6 \mathrm{ppm} \mathrm{Sb}$, and $36 \mathrm{ppm} \mathrm{Sn}$ (Burleigh and Lear, 1994). Newberry (1995) classified the Mitchell prospect as an Au-rich Cu skarn. However, the results of soil sampling conducted by WGM, Inc., in 1976 to 1977 indicate that $\mathrm{Zn}$ is more widespread than copper (U.S. Bureau of Mines, 1995). 
Table 5. Lead-isotopic compositions of sulfide samples from the Fortymile district, east central-Alaska.

[Analyses by J.E. Gabites at the Pacific Centre for Isotopic and Geochemical Research, University of British Columbia. Lead-isotopic ratios corrected for mass fractionation of $0.10 \% / a m u$, based on replicate analysis of the NBS-981 common Pb standard and the composition recommended by Thirwall (2000). Errors given at the 2 sigma level]

\begin{tabular}{|c|c|c|c|c|c|c|c|c|c|c|c|}
\hline Sample & Mineral & ${ }^{206} \mathrm{~Pb} /{ }^{204} \mathrm{~Pb}$ & Error & ${ }^{207} \mathrm{~Pb} /{ }^{204} \mathrm{~Pb}$ & Error & ${ }^{208} \mathrm{~Pb} /{ }^{204} \mathrm{~Pb}$ & Error & ${ }^{207} \mathrm{~Pb} /{ }^{206} \mathrm{~Pb}$ & Error & ${ }^{208} \mathrm{~Pb} /{ }^{206} \mathrm{~Pb}$ & Error \\
\hline 07ADb02A (Oscar) & pyrite & 19.301 & 0.04 & 15.645 & 0.08 & 39.106 & 0.12 & 0.8112 & 0.160 & 2.0256 & 0.040 \\
\hline LWM 06-01-37 & sphalerite & 19.521 & 0.17 & 15.681 & 0.20 & 39.210 & 0.23 & 0.8033 & 0.054 & 2.0086 & 0.097 \\
\hline 07ADb03B (Eva) & galena & 19.329 & 0.05 & 15.698 & 0.08 & 39.204 & 0.12 & 0.8128 & 0.161 & 2.0278 & 0.041 \\
\hline FMM1 (LWM) & galena & 19.443 & 0.09 & 15.693 & 0.14 & 39.353 & 0.18 & 0.8071 & 0.045 & 2.0241 & 0.091 \\
\hline FMM2 (Eva) & galena & 19.317 & 0.09 & 15.692 & 0.14 & 39.214 & 0.18 & 0.8123 & 0.045 & 2.0300 & 0.091 \\
\hline
\end{tabular}

\section{Drumstick Prospect}

The Drumstick prospect is $2.2 \mathrm{~km}$ north-northwest of the Eva Creek prospect (fig. 5), and consists of gossan that locally contains relict grains of galena and sphalerite. No other sulfides are known to be present in the weathered surficial materials, but analyses of two grab samples from prospect pits dug in 2007 included 22 percent $\mathrm{Zn}$, 19 percent $\mathrm{Pb}$, and $222 \mathrm{~g}$ /tonne $\mathrm{Ag}$, and 12 percent $\mathrm{Zn}, 8$ percent $\mathrm{Pb}$, and $863 \mathrm{~g} /$ tonne $\mathrm{Ag}$, in addition to anomalous $\mathrm{Au}$ and $\mathrm{Cu}$ (Light and others, 2008).

\section{Lead-Isotope Studies}

The isotopic composition of $\mathrm{Pb}$ in sulfides provides a valuable method for identifying the source reservoir(s) from which the $\mathrm{Pb}$ in mineral deposits and occurrences was derived (for example, Doe and Zartman, 1979). Lead-isotopic compositions of sulfides in various types of intrusion-related mineralization, such as proximal skarns, porphyry-type deposits, or more distal veins, typically are similar to those of igneous feldspars in genetically related intrusion(s), suggesting that the $\mathrm{Pb}$ and, by inference, other contained metals are mainly of magmatic derivation (Tosdal and others, 1999). Therefore, in areas of prolonged or episodic pluton emplacement, it may be possible to identify a specific intrusion that is genetically related to the mineralization by comparing the $\mathrm{Pb}$-isotopic compositions of sulfides in the mineral deposits to those of igneous feldspars in the same area. Lead-isotopic compositions of igneous feldspars from Late Triassic, Early Jurassic, and Cretaceous plutons, and of sulfides from a variety of syngenetic and epigenetic mineral deposits are available from western Yukon and eastern and east-central Alaska, and are discussed below.

Here we report five new sulfide $\mathrm{Pb}$-isotopic analyses for the Eva Creek and LWM carbonate-hosted, basemetal prospects and for the Oscar $\mathrm{Cu}-\mathrm{Zn}-\mathrm{Pb}-\mathrm{Ag}$ skarn occurrence. Data are presented in table 5 and are shown graphically on a ${ }^{207} \mathrm{~Pb} /{ }^{204} \mathrm{~Pb}$ versus ${ }^{206} \mathrm{~Pb} /{ }^{204} \mathrm{~Pb}$ plot in figure 13. Also shown for reference are $\mathrm{Pb}$-isotopic data fields for syngenetic, sedimentary-exhalative (SEDEX) $\mathrm{Zn}-\mathrm{Pb}$ occurrences hosted by the Devonian-Mississippian Nasina assemblage in western Yukon and eastern Alaska (Mortensen and others, 2006), igneous feldspars from a suite of Early Jurassic intrusions in western Yukon (Tafti, 2005), igneous feldspars from intermediate-composition and felsic intrusions in the Goodpaster mining district in east-central Alaska (Dilworth and others, 2007), igneous feldspars from a suite of Early and Late Cretaceous intrusions in east-central Alaska (Aleinikoff and others, 2000), and igneous K-feldspar from the Late Triassic Taylor Mountain granodiorite and Early Jurassic Mount Veta syenite (Aleinikoff and others, 1987). The plot additionally shows $\mathrm{Pb}$-isotopic compositions for sulfides in Au-bearing, epigenetic veins in the area of the Pogo mine in the Goodpaster district (Dilworth and others, 2007), for mixed sulfides from the Mitchell skarn occurrence (fig. 5; Newberry, 1995), for three galena samples from carbonate-replacement(?) rock at the Lead Creek prospect, and for one galena sample (upper purple dot) from skarn at the Champion Creek prospect (Dusel-Bacon and others, 2003).

Data for epigenetic sulfide occurrences from both the Lead Creek-Champion Creek area and the Mount Veta area in the Fortymile mining district, and from the Goodpaster mining district to the west, have a range of $\mathrm{Pb}$-isotopic compositions that overlap the field of igneous feldspar $\mathrm{Pb}$ compositions for Cretaceous intrusive rocks in the same area, but are completely different from those of igneous feldspars from Early Jurassic intrusions in the western Yukon (fig. 13). Two Pb-isotopic analyses of igneous K-feldspar from Late Triassic and Early Jurassic intrusions in eastern Alaska (Taylor Mountain batholith and Mount Veta syenite; Aleinikoff and others, 1987) are very different. Data for the Taylor Mountain sample plot with the field of western Yukon Early Jurassic intrusive feldspars defined by Tafti (2005), whereas the composi- 


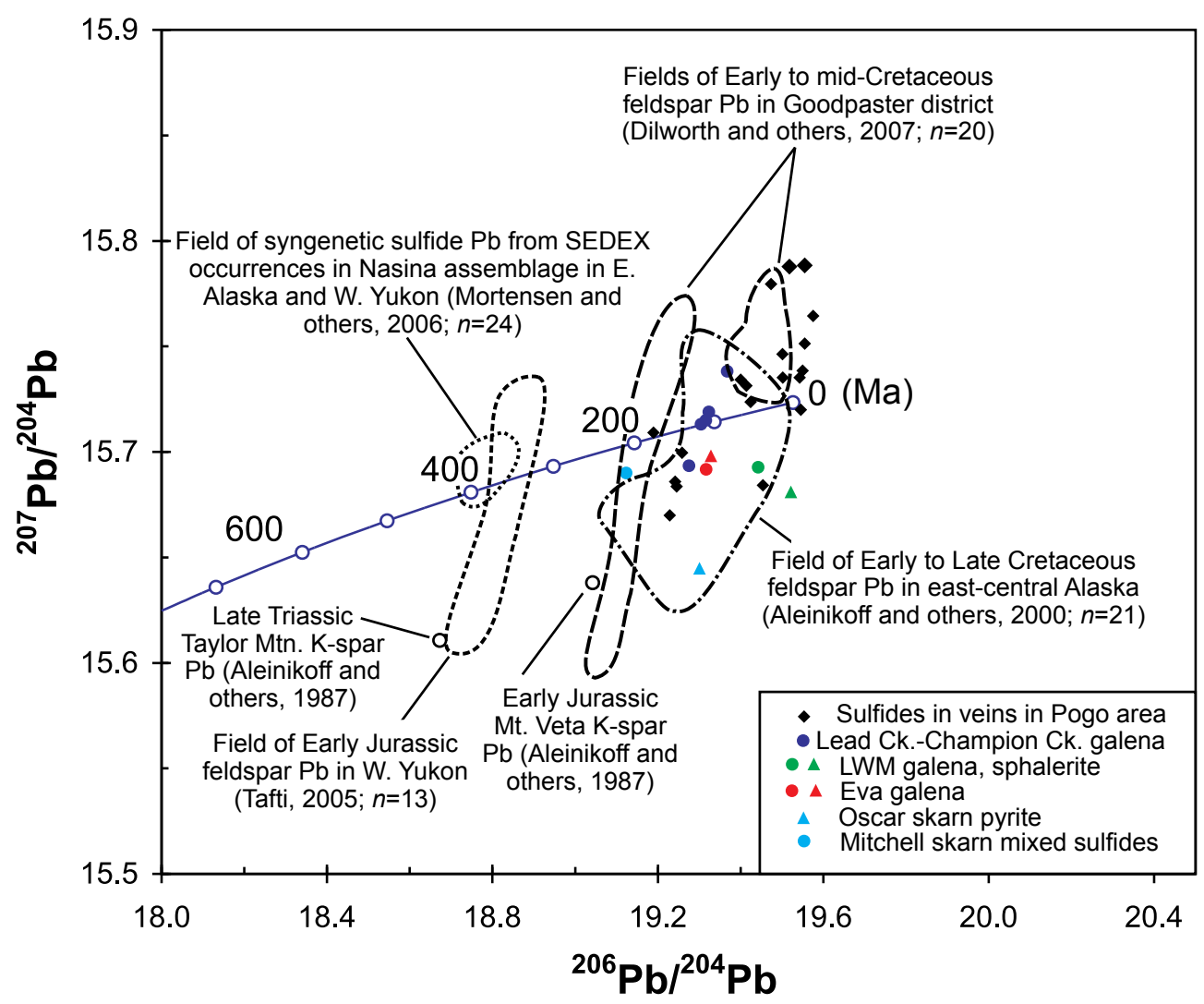

Figure 13. ${ }^{207} \mathrm{~Pb} /{ }^{204} \mathrm{~Pb}$ versus ${ }^{206} \mathrm{~Pb} /{ }^{204} \mathrm{~Pb}$ diagram for $\mathrm{Pb}$ in sulfides from mineral occurrences and in feldspars from igneous rocks from east-central Alaska and western Yukon. See text for references of sulfide $\mathrm{Pb}$. The "shale curve" of Godwin and Sinclair (1982) is shown for reference.

tion of the feldspar from the Mount Veta syenite is more similar to those of Early Cretaceous igneous feldspars in eastern and east-central Alaska (fig. 2). This discrepancy is somewhat puzzling, given that in western Yukon the Late Triassic through Early Jurassic magmatism is interpreted to be the product of a single, long-lived, continental magmatic arc (for example, Mortensen and others, 2000). Additional feldspar $\mathrm{Pb}$-isotopic determinations for Late Triassic and Early Jurassic plutons in the southern Eagle quadrangle, which we plan to undertake in 2009, will test this apparent discrepancy.

Although the $\mathrm{Pb}$-isotopic composition of Mount Veta K-feldspar is more radiogenic than that of the Early Jurassic plutons in western Yukon, it is less radiogenic than the pyrite from the Oscar skarn, which occurs within a few hundred meters of the contact of the Mount Veta syenite. The pyrite from Oscar, like most sulfides from the other base-metal occurrences in the Fortymile district, has $\mathrm{Pb}$-isotopic compositions that imply (but do not require) derivation from Cretaceous rather than Early
Jurassic intrusions. An even greater implied age disparity exists between the radiogenic $\mathrm{Pb}$-isotopic values for the LWM sulfides and the more primitive $\mathrm{Pb}$-isotopic values that one would expect for the Late Triassic (210 Ma) granodiorite drill-core sample that was dated in this study, assuming that its values should be similar to those for the coeval Taylor Mountain batholith (fig. 13). The more radiogenic composition of the LWM sulfides, relative to those of the Eva Creek or Lead Creek sulfides (fig. 13), could indicate a somewhat younger age of mineralization for the LWM deposit.

\section{Discussion}

\section{Mesozoic Plutonism}

Based on the low quartz content, abundance of hornblende, absence of normative corundum, and $\mathrm{Pb}$-isotopic ratios of K-feldspar from the Late Triassic Taylor Mountain 
batholith and the Jurassic Mount Veta syenite, Aleinikoff and others (1987) and Foster and others (1994) concluded that these rocks had an island-arc magmatic origin. Foster and others (1994) concurred with the widely held model, initially proposed by Templeman-Kluit (1979), in which the Triassic and Jurassic plutons were the roots of an island arc that formed within a rifted continental fragment (Fortymile River assemblage of current terminology) and was rejoined to North America in the Jurassic. Closure of the Seventymile/Slide Mountain ocean by west-dipping subduction beneath the rifted crustal fragment, which included the Fortymile River assemblage, is recorded by Permian and possibly Triassic arc magmatism in the upper plate rocks (for example, Hansen and Dusel-Bacon, 1998; Nelson and others, 2006). Berman and others (2007) documented a $\sim 239$ Ma high-pressure ( $\sim 0.9 \mathrm{GPa})$ metamorphic episode in amphibolite-facies rocks, equivalent to the Fortymile River assemblage, in the Stewart River quadrangle (fig. 2) in Yukon, based on U-Pb SHRIMP ages for monazite inclusions in garnet porphyroblasts; they interpreted this episode to have accompanied intra-arc thickening during west-dipping subduction of the former Slide Mountain oceanic lithosphere. Recent mapping and detrital zircon $\mathrm{U}-\mathrm{Pb}$ data from a Triassic overlap assemblage in eastern Yukon show that detritus from the rifted crustal fragment (Yukon-Tanana terrane, as defined by Nelson and others, 2006; fig. 1) is first recognized on the western margin of North America by Early Triassic (Smithian) time (Mortensen and others, 2007; Beranek and Mortensen, 2007).

Shortening and crustal thickening continued into the Jurassic, following collision between the outboard crustal fragment and the underlying continental margin, including the Lake George assemblage (figs. 1-3). High-pressure (7-12 kb) amphibolite-facies metamorphism accompanied this internal duplication in both the upper and lower plates (Dusel-Bacon and others, 1995; Berman and others, 2007). Emplacement of the above-described epidote-bearing biotite leucogranite, at lower crustal depths, was attributed by Day and others (2002) to intrusion during the waning stages of this high-pressure episode; we concur with this interpretation and broaden it to include the other Early Jurassic epidote-bearing granitoids in the Fortymile area. The overlap in estimated pressure conditions for magma consolidation of the epidote-bearing granodiorite samples at localities 10 and 11 and for peak metamorphic pressures determined for metamorphic rocks in the area, described in a previous section, suggests an early to synkinematic relationship of intrusion and contractional deformation. Aluminum-in-hornblende geobarometry for two Early Jurassic plutons that intrude metamorphic rocks equiva- lent to the Fortymile River assemblage, in Yukon, yield mid-crustal emplacement depths of 16 to $19 \mathrm{~km}$; paleomagnetic data from the plutons suggest that they formed close to their present position on the Jurassic margin of cratonal North America (Symons and others, 2000; McCausland and others, 2002). The more radiogenic $\mathrm{Pb}$ isotopic ratios of the Early Jurassic Mount Veta syenite, relative to those from the Late Triassic Taylor Mountain granodiorite, supports the proposed timing for the transition from closure of the ocean basin to crustal thickening through imbrication.

Lower plate assemblages, most notably the Lake George assemblage, remained tectonically buried for approximately 50 m.y. until a widespread extensional episode at $\sim 135$ to 110 Ma resulted in southeast-vergent deformation and rapid mid-Cretaceous cooling of structurally lower assemblages (Hansen and others, 1991; Pavlis and others, 1993; Hansen and Dusel-Bacon, 1998). Occurrence of rare 110 to $115 \mathrm{Ma} \mathrm{Nb}$-rich alkalic and granitic plutonic rocks in the Yukon-Tanana region is attributed to final stages of the mid-Cretaceous extensional episode (Newberry and others, 1998a). This extension was probably related to the development of a northeast-dipping (present-day coordinates) subduction system outboard of the continental margin (Pavlis, 1989; Pavlis and others, 1993; Hansen and Dusel-Bacon, 1998).

Subsequent to the postulated mid-Cretaceous period of regional extension, widespread intrusion of granitoids with trace- and major-element compositions characteristic of a volcanic-arc setting, including our sample 5 from the Mount Harper batholith, occurred throughout the YukonTanana Upland in mid- to Late-Cretaceous time (108 to 88 Ma; Wilson and others, 1985; Newberry and others, 1998 a and references therein). At leased three rhyolitic calderas, including the Sixtymile Butte caldera, formed during this episode $\sim 93 \mathrm{Ma}$ (Bacon and others, 1990). Granitic plutonism resumed at about 75 to $65 \mathrm{Ma}$ in the northwestern Yukon-Tanana Upland (fig. 2) and, at $69 \mathrm{Ma}$, the Middle Fork caldera formed just east of Mount Harper (Bacon and Lanphere, 1996; fig. 2). Within-plate, alkalic, $\sim 70 \mathrm{Ma}$ plutonic rocks also are present in the Tanacross quadrangle south of the Mount Veta area (Wilson and others, 1985; Newberry and others, 1998b). Subsequent within-plate magmatism from $\sim 60$ to 50 Ma produced comagmatic felsic plutons and mafic dikes, bimodal mafic-felsic volcanic rocks, and shallow intrusions that are scattered throughout east-central Alaska and Yukon (Bacon and others, 1990; Foster and others, 1994; Newberry and others, 1998a). These Late Cretaceous to early Tertiary magmatic episodes are consistent with an extensional event of regional scale. Preservation of the Middle Fork caldera fill between the Mount Harper and Tok faults has been attributed to down- 
dropping of the block southeast of the Mount Harper fault (Foster and others, 1994; Bacon and Lanphere, 1996; Dusel-Bacon and Murphy, 2001). No geochemical analyses are available for rocks of the Middle Fork caldera, but we plan to acquire such data as part of our ongoing studies. The $70 \pm 1$ Ma rhyolite porphyry sample from the Fish drill core (sample 3, figs. 5 and $6 F$, tables 1-3) is located $\sim 10$ $\mathrm{km}$ southeast of the Middle Fork caldera, overlaps it in age, and may be comagmatic with the dated welded tuff from the caldera; however, the drill-core sample is too altered for reliable geochemical tectonic fingerprinting.

\section{Origin of Mineralization}

Our preliminary study of LWM drill core supports the carbonate-replacement model recently proposed by Full Metal Minerals, USA, Inc., (McLeod, 2008). The absence of garnet and pyroxene in the LWM samples we examined argues against a skarn origin for this deposit, and the presence of carbonate gangue with the base-metal sulfides there (fig. 10) is consistent with carbonate-replacement processes (for example, Megaw, 1998).

As of 2004, mineralization at the Eva Creek prospect was thought to be skarn-related (Werdon and others, 2004, and references therein). Full Metal Minerals geologists, however, interpret this also as a carbonate-replacement deposit (McLeod, 2008). The more radiogenic galena $\mathrm{Pb}-$ isotopic ratios for Eva Creek compared to those for the distinctly less radiogenic K-feldspar from the syenite of Mount Veta (fig. 13) suggests that the syenite of Mount Veta is unrelated to the formation of the Eva Creek deposit. The rounded to oval habit of some sphalerite and galena grains at Eva Creek may reflect the replacement of dolomite fragments, similar to the texture illustrated for a carbonate-replacement $\mathrm{Pb}-\mathrm{Zn}$ deposit by Craig and Vaughan (1994, p. 290).

The origin of mineralization at the Fish prospect is more ambiguous. FMM geologists (McLeod, 2008; Light and others, 2008) currently interpret the sulfides there as of carbonate-replacement type, similar to that identified at LWM. One of their lines of evidence is the presence of carbonate strata in the lower plate at Fish and its association with mineralized rocks at the surface at Oscar; carbonate would be instrumental in reacting with mineralizing fluids along mapped structures in the vicinity of both prospects. They further suggest that the mineralized structure at Fish is either related to a thrust fault, as evidenced by folding and disruption of the sequence, or that the sulfide-bearing zones cut structures (Light and others, 2008). However, an alternative hypothesis, suggested by the presence of magnetite and especially pyroxene in many of the Fish samples, is that this deposit formed as a magnetite-bearing Zn skarn (see classifications of Einaudi and others, 1981; Meinert, 1993; and Meinert and others, 2005). Additional evidence for this skarn origin includes the interval in core described above that contains elevated B (as much as $286 \mathrm{ppm}$ ) and also Sn (as much as $186 \mathrm{ppm}$ ), and the proximity of an Early Jurassic pluton to the deposits.

The presence in the Fortymile district of base-metal sulfides within both calc-silicate-rich skarns and calcsilicate-free CRDs may reflect multistage mineralization by magmatic-hydrothermal systems during the emplacement of two or more magmatically unrelated igneous intrusions. Alternatively, all of the mineralized occurrences could be products of one regionally zoned system that formed during the intrusion of a single, as yet unidentified, pluton. $\mathrm{Zn}-\mathrm{Pb}$ skarns in Alaska, like many of those worldwide, commonly occur distal to major magmatic-hydrothermal systems, including porphyry Mo and $\mathrm{Cu}$ deposits (Newberry and others, 1997). ${ }^{40} \mathrm{Ar} /{ }^{39} \mathrm{Ar}$ dating of Mo-Cu prospects in the eastern Yukon-Tanana Upland indicates that the area includes mid-Cretaceous, Late Cretaceous, and early Tertiary porphyry systems (Newberry and others, 1998). Evaluation of a possible correlation of the skarns and carbonate replacement deposits in the western Fortymile district with a specific porphyry system awaits additional dating of the prospects and nearby intrusions. Regardless of the timing of these mineralizing events, however, the Fortymile district likely has a potential for additional mineral discoveries. These include $\mathrm{W}$ residing in wolframite, and possibly in scheelite, and (or) Sn in cassiterite, within known and concealed calc-silicate skarns, and base-metals plus $\operatorname{Ag}( \pm \mathrm{Au})$ within concealed CRDs. The latter deposit type characteristically occurs in the distal parts of zoned hydrothermal systems, such as in northern Mexico where some major Ag-Pb-Zn-Cu manto and chimney ore bodies (for example, Santa Eulalia) extend more than $2 \mathrm{~km}$ laterally and more than $1 \mathrm{~km}$ vertically (Megaw, 1998; Megaw and others, 1988)In addition to the likely origin of some of the base-metal occurrences by intrusion-related hydrothermal fluids, proximity of the LWM prospect to the northeaststriking, high-angle Kechumstuk Fault (fig. 5) suggests that fluid flow along the fault also may have played an important role during carbonate-replacement mineralization, as suggested by Cooley (2007). This northeast-striking fault is one of many present in the Yukon-Tanana Upland (Foster and others, 1994). These faults have been interpreted to record left-lateral movement and clockwise rotation of blocks resulting from right-lateral movement along both the Tintina and Denali Fault systems, which truncate the northern boundary of the Yukon-Tanana Upland and the southern boundary of similar rocks in the northern Alaska Range, respectively (Page and others, 1995). Map separations 
across the northeast-striking faults indicate both left-lateral and vertical apparent displacement. Recent geologic investigations in the southeastern part of the Big Delta quadrangle (fig. 2), west of our study area, have identified a major northeast-trending structural corridor, the Black Mountain tectonic zone (O’Neill and others, in press). This tectonic zone coincides with geophysical anomalies, is clearly a deep structure, and probably controlled the emplacement of mid-Cretaceous to early Tertiary magmatic rocks, including those associated with some gold deposits (O'Neill and others, in press). Drill results from base-metal prospects in the Fortymile district, combined with geologic and petrologic studies that include U-Pb dating of intrusions, $\mathrm{Pb}$-isotopic analyses of sulfides and igneous feldspars, and determinations of the timing and nature of deformation, will address the origin(s) of the various base-metal deposits and occurrences in the Fortymile district, including the role that these faults may have played during mineralization.

\section{Acknowledgments}

We thank Full Metal Minerals, USA, Inc., especially Rob McLeod, Vice President of Exploration, for access to drill core and company reports for the Fortymile region. Norman Phillips of Doyon, Ltd., facilitated our initial visit to the Fortymile property in 2007 and provided copies of previous company reports on Doyon's selected or conveyed lands within our Fortymile study area. Charlie Bacon supplied invaluable help in the field, including sample collection and logistics. Preparation of final illustrations by Niki Wintzer is appreciated. We thank Renee Pillers for mineral separation work and Karl Evans and David Adams for help with SEM imaging of zircons. Discussions with Cullan Lester (Alaska Earth Sciences), Richard Moses (FMM), and Chris Siron (FMM) were helpful. We greatly appreciate the efforts of Joseph Wooden and Frank Mazdab (both USGS) in ensuring that the USGS/Stanford SHRIMP-RG instrument worked well during our analytical session. Detailed reviews by Jane Hammarstrom (USGS) and Melanie Werdon (Alaska Division of Geological and Geophysical Surveys) improved the manuscript. Ted Theodore (USGS) also provided helpful comments.

\section{References}

Aleinikoff, J.N., Dusel-Bacon, Cynthia, Foster, H.L., and Nokleberg, W.J., 1987, Pb-isotopic fingerprinting of tectonostratigraphic terranes, east-central Alaska:
Canadian Journal of Earth Sciences, v. 24, p. 2089 2098.

Aleinikoff, J.N., Farmer, G.L., Rye, R.O., and Nokleberg, W.J., 2000, Isotopic evidence for the sources of Cretaceous and Tertiary granitic rocks, east-central Alaska-Implications for the tectonic evolution of the Yukon-Tanana terrane: Canadian Journal of Earth Sciences, v. 37, p. 945-956.

Bacon, C.R., and Druitt, T.H., 1988, Compositional evolution of the zoned calcalkaline magma chamber of Mount Mazama, Crater Lake, Oregon: Contributions to Mineralogy and Petrology, v. 98, p. 224-256.

Bacon, C.R., Foster, H.L., and Smith, J.G., 1990, Rhyolitic calderas of the Yukon-Tanana terrane, eastcentral Alaska-Volcanic remnants of a mid-Cretaceous magmatic arc: Journal of Geophysical Research, v. 95, no. B13, p. 21,451-21,461.

Bacon, C.R., and Lanphere, M.A., 1996, Late Cretaceous age of the Middle Fork caldera, Eagle quadrangle, eastcentral Alaska, in Moore, T.E., and Dumoulin, J.A., eds., Geologic studies in Alaska by the U.S. Geological Survey, 1994: U.S. Geological Survey Bulletin 2152, p. 143-147 [http://pubs.er.usgs.gov/djvu/B/bull_2152. djvu last accessed December 4, 2008].

Baldwin, S.L., Harrison, T.M., and FitzGerald, J.D., 1990, Diffusion of ${ }^{40} \mathrm{Ar}$ in metamorphic hornblende: Contributions to Mineralogy and Petrology, v. 105, p. 691-703.

Barker, F., 1979, Trondhjemite: Definition, environment and hypotheses of origin, in Barker, F., ed., Trondhjemites, dacites, and related rocks: Amsterdam, Elsevier Scientific Publishing Co., p. 1-12.

Barton, P.B., Jr., and Bethke, P.M., 1987, Chalcopyrite disease in sphalerite; Pathology and epidemiology: American Mineralogist, v. 72, no. 5-6, p. 451-467.

Beranek, L.P., and Mortensen, J.K., 2007, Investigating a Triassic overlap assemblage in Yukon-Ongoing field studies and preliminary detrital-zircon age data, in Emond, D.S., Lewis, L.L., and Weston, L.H., eds., Yukon Exploration and Geology, 2006: Yukon Geological Survey, p. 83-92.

Berman, R.G., Ryan, J.J., Gordey, S.P., and Villeneuve, Mike, 2007, Permian to Cretaceous polymetamorphic evolution of the Stewart River region, Yukon-Tanana terrane, Yukon, Canada-P-T evolution linked with in situ SHRIMP monazite geochronology: Journal of Metamorphic Geology, v. 25, p. 803-827.

Black, L.P., Kamo, S.L., Allen, C.M., Davis, D.W., Aleinikoff, J.N., Valley, J.W., Mundil, R., Campbell, I.H., Korsuch, R.J., Williams, I.S., and Foudoulis, C., 2004, Improved ${ }^{206} \mathrm{~Pb} /{ }^{238} \mathrm{U}$ microprobe geochronology by the monitoring of a trace-element-related matrix 
effect; SHRIMP, ID-TIMS, ELA-ICP-MS and oxygen isotope documentation for a series of zircon standards: Chemical Geology, v. 205, p. 115-140.

Burleigh, R.E., and Lear, K.G., 1994, Compilation of data for phase 1 of the mineral resource evaluation of the Bureau of Land Management Black River and Fortymile River subunits: U.S. Bureau of Mines OpenFile Report 48-94, 116 p.

Burns, L.E., U.S. Bureau of Land Management, Fugro Airborne Surveys Corp., and Stevens Exploration Management Corp., 2008, Line, grid, and vector data, plot files, and descriptive project report for the airborne geophysical survey of part of the western Fortymile mining district, east-central Alaska: Alaska Division of Geological and Geophysical Surveys Geophysical Report 2008-1, 9 sheets, 1 disk, scale 1:63,360.

Carter, C.H., 1981, Doyon exploration program, Blocks 4, 5, 8, and 22: Doyon, Ltd. Report 81-27. (unpub. report held by Doyon, Ltd., Fairbanks, Alaska).

Colpron, Maurice, Nelson, J.L., and Murphy, D.C., 2006, A tectonostratigraphic framework for the pericratonic terranes of the northern Canadian Cordillera, in Colpron, Maurice, Nelson, J.L., and Thompson, R.I., eds., Paleozoic evolution and metallogeny of pericratonic terranes at the ancient Pacific margin of North America, Canadian and Alaskan Cordillera: Geological Association of Canada Special Paper 45, p. 1-23.

Coney, P.J., Jones, D.L., and Monger, W.H., 1980, Cordilleran suspect terranes: Nature, v. 288, no. 5789, p. 329-333.

Cooley, M.A., 2007, Structural controls of carbonatereplacement mineralization in the 40 Mile Property area and recommendations for further exploration: Report prepared for Full Metal Minerals, USA, Inc., 7 p. (unpub. report held by Doyon, Ltd., Fairbanks, Alaska). Cushing, G.W., 1984, The tectonic evolution of the eastern Yukon-Tanana Upland: Albany, State University of New York, unpub. Master's thesis, $235 \mathrm{p}$.

Craig, J.R., and Vaughan, D.J., 1994, Ore microscopy and ore petrography: New York, John Wiley and Sons, Inc., $434 \mathrm{p}$.

Dashevsky, S.S., Nicol, D.L., and Bond, J., 1986, Mines, prospects, and geochemical anomalies on Doyon, Ltd., regional overselection lands, Alaska, Blocks 1-8: Doyon, Ltd. Report 86-01a, 300 p. (unpub. report held by Doyon, Ltd., Fairbanks, Alaska).

Day, W.C., Aleinikoff, J.N., and Gamble, B.M., 2002, Geochemistry and age constraints on metamorphism and deformation in the Fortymile River area, eastern Yukon-Tanana Upland, Alaska, in Wilson, F.H., and Galloway, J.P., eds., Studies by the U.S. Geological Survey in Alaska, 2000: U.S. Geological Survey
Professional Paper 1662, p. 5-18 [http://pubs.usgs.gov/ pp/pp1662/ accessed December 4, 2008].

Day, W.C., Gamble, B.M., Henning, M.W., and Smith, B.D., 2000, Geologic setting of the Fortymile River area-Polyphase deformational history within part of the eastern Yukon-Tanana Uplands of Alaska, in Kelly, K.D., and Gough, L.P., eds., Geologic studies in Alaska by the U.S. Geological Survey, 1998: U.S. Geological Survey Professional Paper 1615, p. 65-82 [http://pubs. usgs.gov/pp/p1615/ accessed December 4, 2008].

Dilworth, K., Mortensen, J.K., Ebert, S., and Tosdal, R.M., 2007, Cretaceous reduced granitoids in the Goodpaster mining district, east-central Alaska: Canadian Journal of Earth Sciences, v. 44, p. 13471373.

Doe, B.R., and Zartman, R.E., 1979, Plumbotectonics, the Phanerozoic, in Barnes, H.L., ed., Geochemistry of hydrothermal ore deposits ( $2 \mathrm{~d}$ ed.): New York, John Wiley and Sons, p. 22-70.

Dusel-Bacon, Cynthia, and Cooper, K.M., 1999, Traceelement geochemistry of metabasaltic rocks from the Yukon-Tanana Upland and implications for the origin of tectonic assemblages in east-central Alaska: Canadian Journal of Earth Sciences, v. 36, p. 16711695.

Dusel-Bacon, Cynthia, and Harris, A.G., 2003, New occurrences of late Paleozoic and Triassic fossils from the Seventymile and Yukon-Tanana terranes, eastcentral Alaska, with comments on previously published occurrences in the same area, in Galloway, J.P., ed., Studies in Alaska by the U.S. Geological Survey during 2001: U.S. Geological Survey Professional Paper 1678, p. 5-30 [http://geopubs.wr.usgs.gov/prof-paper/pp1678/ accessed December 4, 2008].

Dusel-Bacon, Cynthia, and Murphy, J.M., 2001, Apatite fission-track evidence of widespread Eocene heating and exhumation in the Yukon-Tanana Upland, interior Alaska: Canadian Journal of Earth Sciences, v. 38, p. 1191-1204.

Dusel-Bacon, Cynthia, Csejtey, Béla, Jr., Foster, H.L., Doyle, E.O., Nokleberg, W.J., and Plafker, G., 1993, Distribution, facies, ages, and proposed tectonic associations of regionally metamorphosed rocks in east- and south-central Alaska: U.S. Geological Survey Professional Paper 1497-C, 73 p., 2 sheets, scale 1:1,000,000 [http://pubs.er.usgs.gov/djvu/PP/ pp_1497_c.djvu accessed December 4, 2008].

Dusel-Bacon, Cynthia, Hansen, V.L., and Scala, J.A., 1995, High-pressure amphibolite facies dynamic metamorphism and the Mesozoic tectonic evolution of an ancient continental margin, east-central Alaska: Journal of Metamorphic Geology, v. 13, no. 1, p. 9-24. 
Dusel-Bacon, Cynthia, Hopkins, M.J., Mortensen, J.K., Dashevsky, S.S., Bressler, J.R., and Day, W.C., 2006, Paleozoic tectonic and metallogenic evolution of the pericratonic rocks of east-central Alaska and adjacent Yukon Territory, in Colpron, Maurice, and Nelson, J.L., eds., Paleozoic evolution and metallogeny of pericratonic terranes at the ancient Pacific margin of North America, Canadian and Alaskan Cordillera: Geological Association of Canada Special Paper 45, p. 25-74.

Dusel-Bacon, Cynthia, Lanphere, M.A., Sharp, W.D., Layer, P.W., and Hanson, V.L., 2002, Mesozoic thermal history and timing of structural events for the YukonTanana Upland, east-central Alaska $-{ }^{40} \mathrm{Ar} /{ }^{39} \mathrm{Ar}$ data from metamorphic and plutonic rocks: Canadian Journal of Earth Sciences, v. 39, no. 6, p. 1013-1051.

Dusel-Bacon, Cynthia, Mortensen, J.K., and Fredericksen, Rick, 2003, Cretaceous epigenetic base-metal mineralization at the Lead Creek prospect, eastern Yukon-Tanana Upland, Alaska - Constraints from lead isotopic data from sulfides and zircons, in Galloway, J.P., ed., Studies in Alaska by the U.S. Geological Survey during 2001: U.S. Geological Survey Professional Paper 1678, p. 31-40 [http://geopubs.wr.usgs.gov/prof-paper/ pp1678/ accessed December 4, 2008].

Dusel-Bacon, Cynthia, Wooden, J.L., and Hopkins, M.J., 2004, U-Pb zircon and geochemical evidence for bimodal mid-Paleozoic magmatism and syngenetic base-metal mineralization in the Yukon-Tanana terrane, Alaska: Geological Society of America Bulletin, v. 116, p. $989-1015$.

Einaudi, M.T., Meinert, L.D., and Newberry, R.J., 1981, Skarn deposits, in Skinner, B.J., ed., Economic Geology 75th Anniversary Volume: Lancaster, Pennsylvania, The Economic Geology Publishing Company, p. 317-391.

Foster, H.L., 1976, Geologic map of the Eagle quadrangle, Alaska: U.S. Geological Survey Miscellaneous Investigations Series Map I-922, scale 1:250,000.

Foster, H.L., 1992, Geologic map of the eastern YukonTanana region, Alaska. U.S. Geological Survey OpenFile Report 92-313, scale 1:500,000 [http://pubs. er.usgs.gov/djvu/OFR/1992/ofr_92_313.djvu accessed December 4, 2008].

Foster, H.L., and Clark, S.H.B., 1970, Geochemical and geologic reconnaissance of a part of the Fortymile area, Alaska: U.S. Geological Survey Bulletin 1312-M, p. M1-M29.

Foster, H.L., Albert, N.R.D., Barnes, D.F., Curtin, G.C., Griscom, Andrew, Singer, D.A., and Smith, J.G., 1976, The Alaskan mineral resource assessment programBackground information to accompany folio of geologic and mineral resource maps of the Tanacross quadrangle, Alaska: U.S. Geological Survey Circular 734, 23 p. [http://pubs.er.usgs.gov/djvu/CIR/circ_734. djvu accessed December 4, 2008].

Foster, H.L., Cushing, G.W., Keith, T.E.C., and Laird, J., 1985, Early Mesozoic tectonic history of the Boundary area, east-central Alaska: Geophysical Research Letters, v. 12, no. 9, p. 553-556.

Foster, H.L., Donato, M.M., and Yount, M.E., 1978, Petrographic and chemical data on Mesozoic granitic rocks of the Eagle quadrangle, Alaska: U.S. Geological Survey Open-File Report 78-253, 29 p., 2 maps, scale 1:250,000 [http://pubs.er.usgs.gov/djvu/OFR/1978/ ofr_78_253.djvu accessed December 4, 2008].

Foster, H.L., Keith, T.E.C., and Menzie, W.D., 1994, Geology of the Yukon-Tanana area of east-central Alaska, in Plafker, G., and Berg, H.C., eds., The geology of Alaska, v. G-1 of The geology of North America: Boulder, Colorado, Geological Society of America, p. 205-240.

Full Metal Minerals, USA, Inc., 2008, News release, July 7, 2008. [http://www.fullmetalminerals.com/s/ NewsReleases.asp, last accessed December 4, 2008].

Godwin, C.I., and Sinclair, A.J., 1982, Average lead isotope growth curves for shale-hosted zinc-lead deposits, Canadian Cordillera: Economic Geology, v. 77, p. 675-690.

Gordey, S.P., and Makepeace, A.J., compilers, 1999, Yukon digital geology: Geological Survey of Canada Open File D 3826 and Department of Indian and Northern Affairs, Exploration and Geological Services Division Open File 1999-1(D).

Hammarstrom, J.M., and Zen, E-an, 1992, Petrological characteristics of magmatic epidote-bearing granites of the western Cordillera of America, in Brown, P.E., and Chappell, B.W., eds., The second Hutton symposium on the origin of granites and related rocks [abs.]: Geological Society of America Special Paper 272, p. 490-491.

Hansen, V.L., and Dusel-Bacon, Cynthia, 1998, Structural and kinematic evolution of the Yukon-Tanana Upland tectonites, east-central Alaska: A record of late Paleozoic to Mesozoic crustal assembly: Geological Society of America Bulletin, v. 110, no. 2, p. 211-230.

Hansen, V.L., Heizler, M.T., and Harrison, T.M., 1991, Mesozoic thermal evolution of the Yukon-Tanana composite terrane- New evidence from ${ }^{40} \mathrm{Ar} /{ }^{39} \mathrm{Ar}$ data: Tectonics, v. 10, no. 1, p. 51-76.

Harrison, T.M., Duncan, I., and McDougall, I., 1985, Diffusion of ${ }^{40} \mathrm{Ar}$ in biotite: temperature, pressure and compositional effects: Geochimica et Cosmochimica Acta, v. 49, p. 2461-2468. 
Heaman, L., and Parrish, R., 1991, U-Pb geochronology of accessory minerals, in Heaman, L., and Ludden, J.N., eds., Applications of radiometric isotope systems to problems in geology: Mineralogical Association of Canada Short Course Handbook, v. 19, p. 59-102.

Hildreth, W. and Moorbath, S., 1988, Crustal contributions to arc magmatism in the Andes of central Chile: Contributions to Mineralogy and Petrology, v. 98, p. 455-489.

Hildreth, W., Halliday, A.N., and Christiansen, R.L., 1991, Isotopic and chemical evidence concerning the genesis and contamination of the basaltic and rhyolitic magma beneath the Yellowstone Plateau volcanic field: Journal of Petrology, v. 32, p. 63-138.

Hitzman, M.W., Reynolds, N.A., Sangster, D.F., Allen, C.R., and Carman, C.E., 2003, Classification, genesis, and exploration guides for nonsulfide zinc deposits: Economic Geology, v. 98, p. 685-714.

Hunziker, J.C., Desmons, J., and Hurford, A.J. 1992. Thirty-two years of geochronological works in the central and western Alps-A review on seven maps: Lausanne, Switzerland, University of Lausanne, Memoires de Geologie, v. 13, p. 1-59.

Johnson, D.M., Hooper, P.R., and Conrey, R.M., 1999, $\mathrm{XRF}$ analysis of rocks and minerals for major and trace elements on a single low dilution Li-tetraborate fused bead: Advances in X-ray Analysis, v. 41, p. 843-867.

Knaack, C., Scott, C., and Hooper, P., 1994, Trace element analyses of rocks and minerals by ICP-MS: Pullman, Washington State University, Open-File Report, 18 p.

Lester, Cullan, 2007, Geology and mineralization of the Oscar prospect, Fortymile mining district, Alaska: Report prepared for Full Metal Minerals, USA, Inc., October, 2007, scale: 1:20,000, 17 p. (unpub. report held by Doyon, Ltd., Fairbanks, Alaska).

Light, Jamie, East, Asa, Lester, Cullan, Borovicka, Tom, and Cooley, Mike, 2008, Annual progress report to Doyon Ltd. on the Forty-Mile property: 2007 FortyMile property Annual Report prepared for Full Metal Minerals, USA, Inc., 43 p. (unpub. report held by Doyon, Ltd., Fairbanks, Alaska).

Lindsay, J.M., Schmitt, A.K., Trumbull, R.B., De Silva, S.L., Siebel, W., and Emmermann, R., 2001, Magmatic evolution of the La Pacana caldera system, central Andes, Chile - Compositional variation of two cogenetic, large-volume felsic ignimbrites: Journal of Petrology, v. 42, p. 459-486.

Ludwig, K.R., 2001, Squid, version 1.02, A user's manual: Berkeley Geochronology Center Special Publication No. 2, 21 p.

Ludwig, K.R., 2003, Isoplot/Ex version 3.00, A geochronological toolkit for Mircosoft Excel: Berkeley
Geochronology Center Special Publication No. 4, 73 p.

Maniar, P.D., and Piccoli, P.M., 1989, Tectonic discrimination of granitoids: Geological Society of America Bulletin, v. 101, p. 635-643.

McCausland, P.J.A., Symons, D.T.A., Hart, C.J.R., and Blackburn, W.H., 2002, Paleomagnetism and geobarometry of the Granite Mountain batholith, Yukon: Minimal geotectonic motion of the YukonTanana Terrane relative to North America, in Emond, D.S., Weston, L.H., and Lewis, L.L., eds., Yukon exploration and geology 2001: Exploration and Geological Services Division, Yukon, Indian and Northern Affairs Canada, p. 163-177.

McLeod, Robert, 2008, Full Metal Minerals-Carbonatereplacement $\mathrm{Zn}-\mathrm{Pb}-\mathrm{Ag}-\mathrm{Cu}$ discoveries in the 40 Mile district, Alaska [abs.]: Vancouver, British Columbia, Mineral Exploration Roundup, 2008, p. 42-43.

Megaw, P.K.M., 1998, Carbonate-hosted Pb-Zn-Ag$\mathrm{Cu}-\mathrm{Au}$ replacement deposits-An exploration perspective, in Lentz, D.R., ed., Mineralized intrusionrelated skarn systems: Mineralogical Association of Canada Short Course Notes, v. 26, p. 337-357.

Megaw, P.K.M., Ruiz, Joaquin, and Titley, S.R., 1988, High-temperature, carbonate-hosted Ag- $\mathrm{Pb}-\mathrm{Zn}(\mathrm{Cu})$ deposits of northern Mexico: Economic Geology, v. 83, no. 8 , p. $1856-1885$.

Meinert, L.D., 1993, Igneous petrogenesis and skarn deposits, in Kirkham, R.V., Sinclair, W.D., Thorpe, R.I., and Duke, J.M., eds., Mineral deposit modeling: Geological Association of Canada Special Paper 40, p. 569-583.

Meinert, L.D., Dipple, G.M., and Nicolescu, S., 2005, World skarn deposits, in Hedenquist, J.W., Thompson, J.F.H., Goldfarb, R.J., and Richards, J.P., eds., Economic geology one hundredth anniversary volume, 1905-2005: Littleton, Colorado, Society of Economic Geologists, Inc., p. 299-336.

Miyashiro, Akiho, 1974, Volcanic rock series in island arcs and active continental margins: American Journal of Science, v. 274, p. 321-355Mortensen, J.K., 1988, Geology of southwestern Dawson map area, Yukon Territory (NTS 116 B, C): Geological Survey of Canada Open File 1927.

Mortensen, J.K., 1990, Geology and U-Pb geochronology of the Klondike District, west-central Yukon Territory: Canadian Journal of Earth Sciences, v. 27, p. 903-914.

Mortensen, J.K., 1992, Pre-mid-Mesozoic tectonic evolution of the Yukon-Tanana terrane, Yukon and Alaska: Tectonics, v. 11, no. 4, p. 836-853.

Mortensen, J.K., 1996, Geological compilation maps of the northern Stewart River map area, Klondike and Sixty Mile districts: Exploration and Geological 
Services Division, Yukon, Indian and Northern Affairs Canada, Open File 1996-1(G), scale 1:50,000.

Mortensen J.K., Beranek, Luke, and Murphy, D.C., 2007, Permo-Triassic orogeny in the northern Cordillera: Sonoma north? [abs.]: Geological Society of America Abstracts with Programs, v. 39, no. 4, p. 69.

Mortensen J.K., Dusel-Bacon, Cynthia, Hunt, Julie, and Gabites Janet, 2006, Lead isotopic constraints on the metallogeny of middle and late Paleozoic syngenetic base metal occurrences in the YukonTanana and Slide Mountain/Seventymile terranes and adjacent portions of the North American miogeocline, in Colpron, Maurice, Nelson, J.L., and Thompson, R.I., eds., Paleozoic evolution and metallogeny of pericratonic terranes at the ancient Pacific margin of North America, Canadian and Alaskan Cordillera: Geological Association of Canada Special Paper 45, p. 261-280.

Mortensen, J.K., Emon, K., Johnston, S.T., and Hart, C.J.R., 2000, Age, geochemistry, paleotectonic setting and metallogeny of Late Triassic-Early Jurassic intrusons in the Yukon and eastern Alaska: A preliminary report, in Emond, D.S., and Weston, L.H., eds., Yukon Exploration and Geology 1999: Exploration and Geological Services Division, Yukon, Indian and Northern Affairs Canada, p. 139-144.

Mortensen, J.K., Ghosh, D. and Ferri, F., 1995, U-Pb age constraints of intrusive rocks associated with coppergold porphyry deposits in the Canadian Cordillera, in Schroeter, T.G., ed., Porphyry deposits of the northwestern Cordillera of North America: Canadian Institute of Mining Metallurgy and Petroleum, Special Volume 46, p. 142-158.

Murphy, D.C., Mortensen, J.K., Piercey, S.J., Orchard, M.J., and Gehrels, G.E., 2006, Mid-Paleozoic to early Mesozoic tectonostratigraphic evolution of YukonTanana and Slide Mountain terranes and affiliated overlap assemblages, Finlayson Lake massive sulphide district, southeastern Yukon, in Colpron, Maurice., Nelson, J.L., and Thompson, R.I., eds., Paleozoic evolution and metallogeny of pericratonic terranes at the ancient Pacific margin of North America, Canadian and Alaskan Cordillera: Geological Association of Canada Special Paper 45, p. 75-105.

Nelson, J.L., Colpron, Maurice, Piercey, S.J., DuselBacon, Cynthia, Murphy, D.C., and Roots, C.F., 2006, Paleozoic tectonic and metallogenetic evolution of pericratonic terranes in Yukon, northern British Columbia and eastern Alaska, in Colpron, Maurice, Nelson, J.L., and Thompson, R.I., eds., Paleozoic evolution and metallogeny of pericratonic terranes at the ancient Pacific margin of North America, Canadian and Alaskan Cordillera: Geological Association of Canada Special Paper 45, p. 323-360.

Newberry, R.J., 1995, An update on skarn deposits of Alaska: Alaska Division of Geological and Geophysical Surveys Public-Data File 95-20, 72 p.

Newberry, R.J., Allegro, G.L., Cutler, S.E., HagenLevelle, J.H., Adams, D.D., Nicholson, L.C., Weglarz, T.B., Bakke, A.A., Clautice, K.H., Coulter, G.A., Ford, M.J., Myers, G.L., and Szumigala, D.J., 1997, Skarn deposits of Alaska, in Goldfarb, R.J., and Miller, L.D., eds., Economic Geology Monograph 9, Mineral deposits of Alaska: Economic Geology Publishing Company, p. 355-395.

Newberry, R.J., Bundtzen, T.K., Mortensen, J.K., and Weber, F.R., 1998a, Petrology, geochemistry, age, and significance of two foliated intrusions in the Fairbanks district, Alaska, in Gray, J.E., and Riehle, J.R., eds., Geologic studies in Alaska by the United States Geological Survey, 1996: U.S. Geological Survey Professional Paper 1595, p. 117-129 [http://pubs.er.usgs. gov/djvu/PP/pp_1595.djvu accessed December 4, 2008].

Newberry, R.J., Layer, P.W., Burleigh, R.E., and Solie, D.N., 1998b, New ${ }^{40} \mathrm{Ar} /{ }^{39} \mathrm{Ar}$ dates for intrusions and mineral prospects in the eastern Yukon-Tanana terrane, Alaska, in Gray, J.E., and Riehle, J.R., eds., Geologic studies in Alaska by the United States Geological Survey, 1996: U.S. Geological Survey Professional Paper 1595, p. 131-160 [http://pubs.er.usgs.gov/djvu/ PP/pp_1595.djvu accessed December 4, 2008].

O'Neill, J.M., Day, W.C., Aleinikoff, J.N., and Saltus, R.W., in press, The Black Mountain tectonic zone-A reactivated northeast-trending crustal shear zone in the Yukon-Tanana Upland of east-central Alaska, in Gough, L.P., and Day, W.C., eds., Recent U.S. Geological Survey studies in the Tintina Gold Province Alaska, USA, and Yukon Territory, Canada-Summary results of a five-year project: U.S. Geological Survey, Scientific Investigations Report 2007-5289.

Page, R.A., Plafker, George, and Pulpan, Hans, 1995, Block rotation in east-central Alaska: A framework for evaluating earthquake potential?: Geology, v. 23 , no. 7 , p. 629-632.

Pavlis, T.L., 1989, Middle Cretaceous orogenesis in the northern Cordillera-A Mediterranean analogue of collision-related extensional tectonics: Geology, v. 17, p. 947-950.

Pavlis, T.L., Sisson, V.B., Foster, H.L., Nokleberg, W.J., and Plafker, G., 1993, Mid-Cretaceous extensional tectonics of the Yukon-Tanana terrane, Trans-Alaskan Crustal Transect (TACT), east-central Alaska: Tectonics, v. 12, p. 103-122. 
Pearce, J.A., 1982, Trace element characteristics of lavas from destructive plate boundaries, in Thorpe, R.S., ed. Andesites: New York, John Wiley and Sons, p. 525-548.

Pearce, J.A., Harris, N.B.W., and Tindle, A.G., 1984, Trace element discrimination diagrams for the tectonic interpretation of granitic rocks: Journal of Petrology, v. 25, p. 956-983.

Piercey, S.J., Nelson, J.L., Colpron, Maurice, DuselBacon, Cynthia, Simard, R.-L., and Roots, C.F., 2006, Paleozoic magmatism and crustal recycling along the ancient Pacific margin of North America: Geochemical constraints from Yukon-Tanana and related terranes in northern British Columbia, Yukon, and eastern Alaska, in Colpron, Maurice, Nelson, J.L., and Thompson, R.I., eds., Paleozoic evolution and metallogeny of pericratonic terranes at the ancient Pacific margin of North America, Canadian and Alaskan Cordillera: Geological Association of Canada Special Paper 45, p. 281-322.

Prindle, L.M., 1909, The Fortymile quadrangle, YukonTanana region, Alaska: U.S. Geological Survey Bulletin $375,52 \mathrm{p}$.

Ragnarsdóttir, K.V., 2008, Rare metals getting rarer: Nature Geoscience, v. 1, p. 720-721.

Ramdohr, Paul, 1969, The ore minerals and their intergrowths: Oxford, U.K., Pergamon Press, 1174 p.

Saunders, R.H., 1962, Report on the examination of the Mitchell copper prospect, Eagle quadrangle: Alaska Division of Mines and Minerals Property Examination 60-11, 4 p., 2 sheets, scale 1:2,400.

Saunders, R.H., 1967, Mineral occurrences in the YukonTanana region, Alaska: Alaska Division of Mines and Minerals Special Report 2, 60 p., 2 sheets, scales $1: 97,178$ and $1: 844,800$.

Schmidt, M.W., and Poli, S., 2004, Magmatic epidote, in Liebscher, A., and Franz, G., eds., Mineralogical Society of America, Reviews in Mineralogy and Geochemistry, v. 56, p. 399-430.

Scott, D.J., and St-Onge, M.R., 1995, Constraints on $\mathrm{Pb}$ closure temperature in titanite based on rocks from the Ungava orogen, Canada-Implications for $\mathrm{U}-\mathrm{Pb}$ geochronology and P-T-t path determinations: Geology, v. 23, no. 12, p. 1123-1126.

Sharp, T.G., and Buseck, P.R., 1993, The distribution of $\mathrm{Ag}$ and $\mathrm{Sb}$ in galena: Inclusions versus solid solution: American Mineralogist, v. 78, p. 85-95.

Silberling, N.J., Jones, D.L., Monger, J.W.H. and Coney, P.J., 1992, Lithotectonic terrane map of the North American Cordillera: U.S. Geological Survey Miscellaneous Investigations Map I-2176, scale $1: 5,000,000$.

Stacey, J.S., and Kramers, J.D., 1975, Approximation of terrestrial $\mathrm{Pb}$ isotope composition by a two-stage model: Earth and Planetary Science Letters, v. 26, p. 207-222.

Streckeisen, A., 1976, To each plutonic rock its proper name: Earth-Science Reviews, v. 12, no. 2, p. 1-33.

Streckeisen, A., and Le Maitre, R.W., 1979, A chemical approach to the modal (QAPF) classification of the igneous rocks: Neues Jahrbuch für Mineralogie Abhandlungen, v. 136, no. 2, p. 169-206.

Steiger, R.H., and Jäger, E., 1977, Subcommission on geochronology, convention on the use of decay constants in geo- and cosmochronology: Earth and Planetary Science Letters, v. 36, p. 359-362.

Sturmann, A.G., and Clement, R.F., 1993, Historical mining regions and districts of Alaska: Alaska Division of Geological and Geophysical Surveys Public Data File 93-49, 1 sheet, scale 1:2,500,000.

Sun, S.-s., and McDonough, W.F., 1989, Chemical and isotopic systematics of oceanic basalts-Implications for mantle composition and processes, in Saunders, A.D., and Norry, M.J., eds., Magmatism in the ocean basins: Geological Society of London Special Publication 42, p. 313-345.

Symons, D.T.A., Williams, P.R., McCausland, P.J.A., Harris, M.J., Hart, C.J.R., and Blackburn, W.H., 2000, Paleomagnetism and geobarometry of the Big Creek Batholith suggests that the Yukon-Tanana terrane has been a parautochthon since Early Jurassic: Tectonophysics, v. 326, no. 1, p. 57-72.

Szumigala, D.J., Newberry, R.J., Werdon, M.B., Athey, J.E., Flynn, R.L., and Clautice, K.H., 2002, Bedrock geologic map of the Eagle A-1 quadrangle, Fortymile mining district, Alaska: Alaska Division of Geological and Geophysical Surveys Preliminary Interpretive Report 2002-1b, scale: 1:63,360.

Tafti, R., 2005, Nature and origin of the Early Jurassic copper (-gold) deposits at Minto and Williams Creek, Carmacks copper belt, western Yukon-examples of deformed porphyry deposits: Vancouver, University of British Columbia, unpublished M.Sc. thesis, 213 p.

Tempelman-Kluit, D.J., 1979, Transported cataclasite, ophiolite and granodiorite in Yukon-Evidence of arccontinent collision: Geological Survey of Canada Paper 79-14, $27 \mathrm{p}$.

Thirwall, M.F., 2000, Inter-laboratory and other errors in $\mathrm{Pb}$ isotope analyses investigated using $\mathrm{a}^{207} \mathrm{~Pb}-{ }^{204} \mathrm{~Pb}$ double spike: Chemical Geology, v. 163, p. 299-322.

Tosdal, R.M., Wooden, J.L., and Rouse, R.M., 1999, Pb isotopes, ore deposits and metallogenic terranes, in Lambert, D.D., and Ruiz, Joaquin, eds., Application of radiogenic isotopes to ore deposits and exploration: Reviews in Economic Geology, v. 12, p. 1-28. 
U.S. Bureau of Mines, 1995, Final report of the mineral resource evaluation of the Bureau of Land Management Black River and Fortymile River subunits: U.S. Bureau of Mines Open File Report OFR79-95, 225 p.

Van Wyck, Nicholas, 2007a, Annual progress report to Doyon Ltd. on the 40 Mile Block: 2006 Annual progress report prepared for Full Metal Minerals, USA, Inc., 25 p. (unpub. report held by Doyon, Ltd., Fairbanks, Alaska).

Van Wyck, Nicholas, 2007b, Detrital zircon ages from the meta-sediments in the Fortymile district, east central Alaska [abs]: Geological Society of America Abstracts with Programs, v. 39, no. 6, p. 490.

Villeneuve, M., Ryan, J.J., Gordey, S. and Piercey, S., 2003, Combining SHRIMP, TIMS U-Pb and Ar-Ar to resolve magmagenesis, metamorphism and fluid flow in three coincident magmatic arcs, Yukon-Tanana Terrane, western Yukon [abs.]: EOS Transactions of the American Geophysical Union, v. 84, no. 46, Fall Meeting Supplement Abstract V32C-1038.

Wedow, Helmuth, Jr., White, M.G., and Tolbert, G.E., 1954, Reconnaissance for radioactive deposits in eastcentral Alaska, 1949: U.S. Geological Survey Circular 335, 22 p. [http://pubs.er.usgs.gov/djvu/CIR/circ_335. djvu accessed December 4, 2008].

Werdon, M.B., Flynn, R.L., and Szumigala, D.J., 2004, Alaska Resource Data File, Eagle quadrangle: U.S. Geological Survey Open-File Report 2004-1056, 418 p. [http://pubs.usgs.gov/of/2004/1056/].

Werdon, M.B., Newberry, R.J., and Szumigala, D.J., 2001, Bedrock geologic map of the Eagle A-2 quadrangle, Fortymile mining district, Alaska: Alaska Division of Geological and Geophysical Surveys Preliminary Interpretive Report 2001-3b, scale: $1: 63,360$.

WGM, Inc., 1998, Veta property, 1997 Annual report, v. 1: Doyon, Ltd. Report 98-10, 227 p. (unpub. report held by Doyon, Ltd., Fairbanks, Alaska).

WGM, Inc., 2001, 2000 Annual progress report on the Champion property, Alaska: Report prepared for Doyon Ltd. on behalf of Ventures Resource Corp., Anchorage, Alaska, 46 p. (unpub. report held by Doyon, Ltd., Fairbanks, Alaska).

Wheeler, J.O. and McFeely, P., 1991, Tectonic assemblage map of the Canadian Cordillera and adjacent parts of the United States of America: Geological Survey of Canada, Map 1712A, scale 1:2,000,000.

Williams, I.S., 1998, U-Th-Pb geochronology by ion microprobe, in McKibben, M.A., Shanks, W.C., III, and Ridley, W.I., eds., Applications of microanalytical techniques to understanding mineralizing processes: Reviews in Economic Geology, v. 7, p. 1-35.

Wilson, F.H., Smith, J.G., and Shew, N., 1985, Review of radiometric data from the Yukon crystalline terrane, Alaska and Yukon Territory: Canadian Journal of Earth Sciences, v. 22, p. 525-537.

Yeend, Warren, 1996, Gold placers of the historical Fortymile River region, Alaska: U.S. Geological Survey Bulletin 2125, $75 \mathrm{p}$.

Zen, E-an, and Hammarstrom, J.M., 1984, Magmatic epidote and its petrologic significance: Geology, v. 12, no. 9 , p. 515-518. 
This page intentionally left blank 


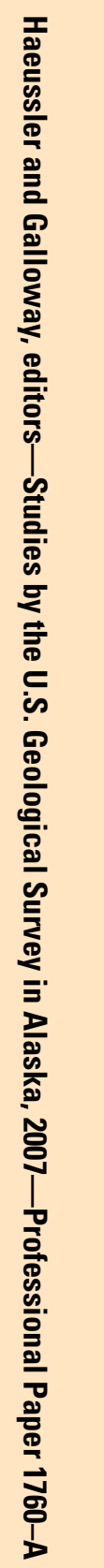

